NISTIR 85-3273-17

(Rev. 4/02)

\title{
Energy Price Indices and Discount Factors for Life-Cycle Cost Analysis - April 2002
}

Annual Supplement to Sieglinde K. Fuller NIST Handbook 135 and Amy S. Rushing

NBS Special Publication 709

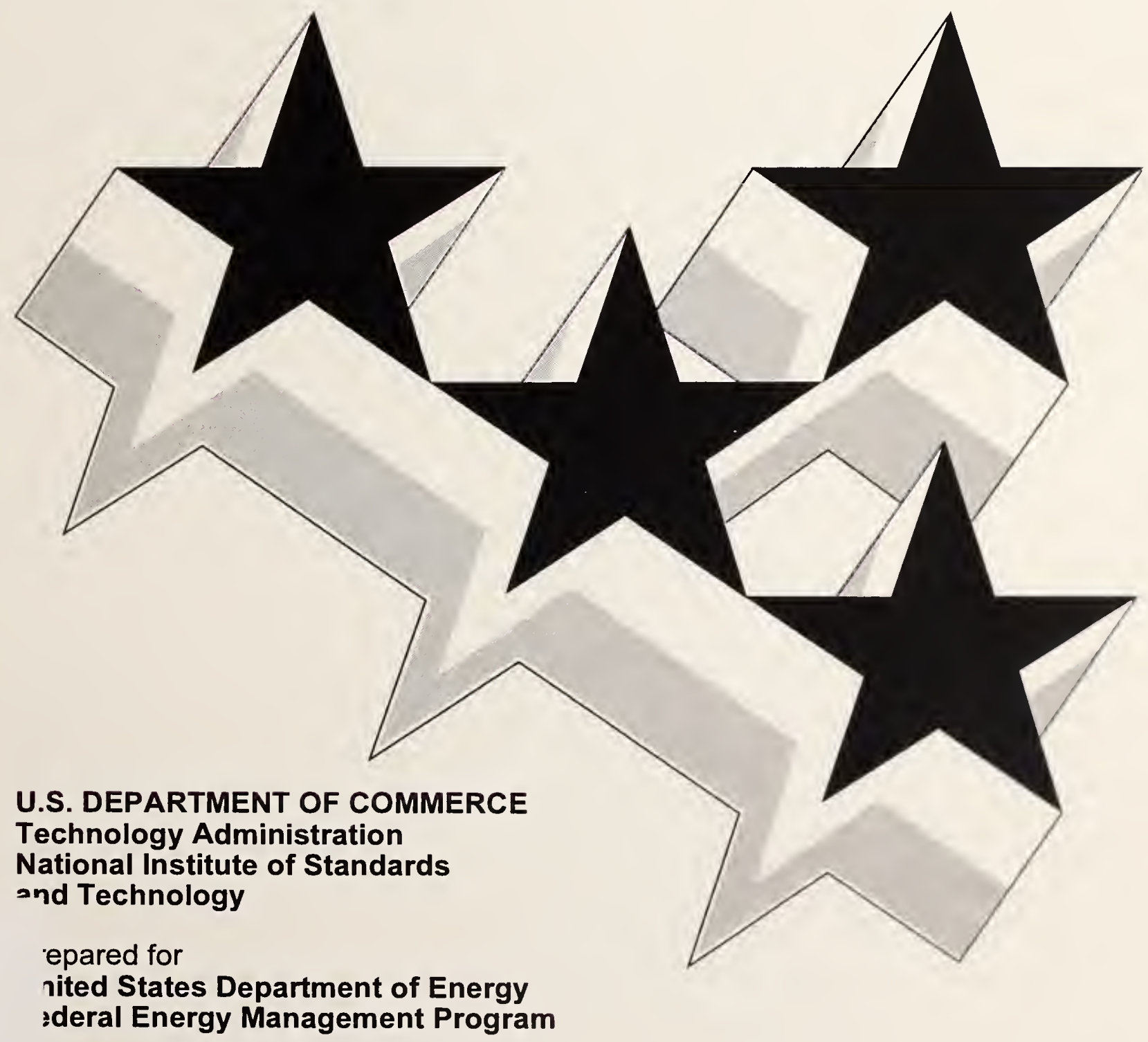

.U56 



\section{ENERGY PRICE INDICES AND DISCOUNT FACTORS FOR LIFE-CYCLE COST ANALYSIS}

Annual Supplement to NIST Handbook 135 and NBS Special Publication 709

\section{April 1, 2002 to March 31, 2003}

Data for the Federal Methodology for Life-Cycle Cost Analysis, Title 10, CFR, Part 436, Subpart A: and for the Energy Conservation Mandatory Performance Standards for New

Federal Residential Buildings, Title 10, CFR, Part 435

Sieglinde K. Fuller

Amy S. Rushing

Office of Applied Economics

April 2002

Building and Fire Research Laboratory

National Institute of Standards and Technology

Gaithersburg, Maryland 20899

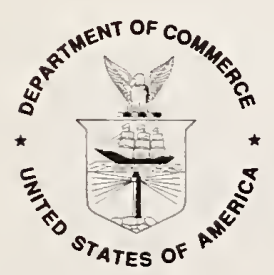

\section{U.S. Department of Commerce}

Donald L. Evans, Secretary

Technology Administration

Philip J. Bond, Under Secretary for Technology

National Institute of Standards and Technology

Arden L. Bement, Jr., Director
Sponsored by:

The Fedcral Energy Management Program

U.S. Department of Energy

Washington, DC 20585 



\begin{abstract}
This is the April 2002 edition of energy price indices and discount factors for performing life-cycle cost analyses of energy and water conservation and renewable energy projects in federal facilities. It will be cffective from April 1, 2002 to March 31,2003. This publication supports the federal lifecyclc costing methodology described in 10CFR436A and Circular A-94 by updating the energy price projections and discount factors that are described, explained, and illustrated in NIST Handbook 135 (HB 135, Life-Cycle Costing Manual for the Federal Energy Management Program.) It supports private-sector life-cycle cost analysis by updating the energy price indices that are described, explained, and illustrated in NBS Special Publication 709 (SP 709).
\end{abstract}




\section{PREFACE}

This is the April 2002 Annual Supplement to NIST Handbook 135, Life-Cycle Costing Manual for the Federal Energy Management Program. The annual supplement provides energy price indices and discount factors for use with the Federal Energy Management Program's (FEMP) procedures for life-cycle cost analysis, as established by the U.S. Department of Energy (DOE) in Subpart A of Part 436 of Title 10 of the Code of Federal Regulations (10 CFR 436A), and amplified in NIST Handbook 135. These indices and factors are provided as an aid to implementing life-cycle cost evaluations of potential energy and water conservation and renewable energy investments in existing and new federally owned and leased buildings.

The update of the Annual Supplement to Handbook 135 is released on April 1 of each year. Its price indices and discount factors are calculated with the most recent energy price projections from DOE's Energy Information Administration (EIA) and the most recent discount rates from FEMP and the Office of Management and Budget (OMB) Circular A-94. This issue of the Annual Supplement is intended for use from April 1, 2002 to March 31, 2003. The updated editions of the NIST Building Life-Cycle Cost (BLCC) programs are released at the same time as this Annual Supplement, for use over the same time period. The software products are discussed below.

At the request of a number of users, a text file of the EIA energy price projections underlying this Annual Supplement has been made available by NIST. For information on obtaining this file (ENCOST02.txt) contact the authors by e-mail at sieglinde.fuller@nist.gov or amy.rushing@nist.gov.

The life-cycle costing methods and procedures, as set forth in 10 CFR 436A, are to be followed by all federal agencies, unless specifically exempted, for evaluating the cost effectiveness of potential energy and water conservation and renewable energy investments in federally owned and leased buildings. For most other federal LCC analyses Circular A-94 provides the relevant guidelines.

As called for by legislation (Energy Policy and Conservation Act, P.L.94-163, 1975, 92 Stat 3206, 42 USC 8252 et seq), the National Institutc of Standards and Technology has provided technical assistance to the U.S. Department of Energy in the development and implementation of life-cycle costing methods and procedures. This is the sccond of a three-volume set, which together provide the methods, data, and computational tools for federal life-cycle cost analysis.

Included in the three-volume set for federal life-cycle cost analysis are the following:

Life-Cycle Costing Mamual for the Federal Energy Management Program, National Institute of Standards and Technology, Handbook 135 (1995).

The manual is a guide to understanding life-cycle costing and related methods of economic analysis as they are applied to federal decisions, especially those subject to 10 CFR 436A rules. It describes the required procedures and assumptions, defines and explains how to apply and interpret economic performance measures, gives examples of federal decision problems and their solutions, explains how to use the energy pricc indices and discount factors that are updated in the Annual Supplement and in the BLCC software, and provides worksheets and other computational aids and instructions 
for calculating the required measures. The 1995 edition of Handbook 135 is a complete revision of the 1987 edition, with updated information on the FEMP LCC requirements of 10 CFR 436A.

Energy Price Indices and Discount Factors for Life-Cycle Cost Analysis, Annual Supplement to NIST Handbook 135 and NBS Special Publication 709, National Institute of Standards and Technology, NISTIR 85-3273.

This report, which is updated annually, provides the current DOE and OMB discount rates, projected energy price indices, and corresponding discount factors needed to estimate the present value of future energy and non-energy project-related costs. Request the latest edition when ordering. (This is the report that you are holding in your hands.)

NIST "Building Life-Cycle Cost" (BLCC) Computer Programs, BLCC5 and BLCC4, National Institute of Standards and Technology. These programs use as default values the same discount factors and energy price projections that underly the discount factor tables in the Annual Supplement. Use versions BLCC 5.1-02 and BLCC 4.9-02 for the period from April 1, 2002 to March 31, 2003.

The BLCC5 program is a windowed version of the DOS-based BLCC4. It is programmed in Java, making it platform-independent, and uses an xml file format. The BLCC5 User's Guide is part of its Help system. BLCC 5.1 has four modules, all of them consistent with the life-cycle cost methodology of 10 CFR 436A, but programmed to include default inputs and nomenclature for specific uses:

\section{(1) FEMP Analysis, Energy Project}

for energy and water conservation and renewable energy projects under the FEMP rules, agency-funded;

(2) Federal Analysis, Financed Project

for federal projects financed through Energy Savings Performance Contracts (ESPC) or Utility Energy Services Contracts (UESC) as authorized by Executive Order 13123 (6/99);

(3) MILCON Analysis, Energy Project

for energy and water conservation and renewable energy projects in military construction. agency-funded;

\section{MILCON Analysis, ECIP Project}

for energy and water conservation projects under the Energy Conservation Investment Program (ECIP).

The remaining user-specific modules now in BLCC4 (i.e., for OMB and non-energy MILCON analyses, and private-sector analyses including taxes and mortgage financing) will be transferred to BLCC5 in the future.

The BLCC4 program is designed to run on IBM PC and compatible microcomputers in a MS-DOS environment. The current version is BLCC 4.9-02. BLCC4-associated programs are the following:

- QuickBLCC (version 2.9-02) can be used to set up multiple project alternatives for LCC analysis in a single input file when only a limited number of inputs are needed. 
- DISCOUNT (version 3.9-02) is a stand-alone program that computes present-value, futurevalue, and annual-value factors for any discount rate and study period, including UPV* factors needed for federal LCC analyses of energy projects.

- $\quad$ ERATES (version 1.11) is a stand-alone program that generates block-rate, time-of-use-rate, and demand-rate schedules for electricity prices. It computes monthly and annual electricity costs that can be imported directly into BLCC4 and entered manually into BLCC5.

- $\quad$ EMISS (version 1.00) is a stand-alone program that generates files of local air-pollution emission coefficients for use with the BLCC4 program.

The NIST BLCC programs provide comprehensive economic analysis capabilities for the evaluation of proposed capital investments that are expected to reduce the long-term operating costs of buildings and building systems. They compute the LCC for project alternatives, compare project alternatives in order to determine which has the lowest LCC, perform annual cash flow analysis, and compute net savings (NS), savings-to-investment ratio (SIR), and adjusted internal rate of return (AIRR) for project alternatives over their designated study period. The BLCC programs can be used to perform economic analysis of capital investment projects undertaken by federal, state, and local government agencies, as well as by the private sector (BLCC4). In their application to federal energy conservation and renewable energy projects, BLCC5 and BLCC4 are consistent with NIST Handbook 135, and the federal life-cycle cost methodology and procedures described in 10 CFR 436 A and Circular A-94. In their application to private-sector and non-federal public-sector projects, they are consistent with ASTM standards for building economics.

The U.S. Department of Energy was directed by legislation and executive order to make available to the private sector the methods, procedures, and related aids developed for federal use. In response to this directive, the National Institute of Standards and Technology, under sponsorship of the U.S. Department of Energy, published a life-cycle costing book for use by the private sector entitled Comprehensive Guide for Least-Cost Energy Decisions, NBS SP 709 (January 1987). The private sector guide is supported by the data provided here, as well as by the BLCC4 computer program. The BLCC4 program supersedes the NBSLCC program that is documented in SP 709.

This Annual Supplement to Handbook 135 can be downloaded from the DOE/FEMP web site at: http://www.eren.doc.gov/femp (click on icon Technical Assistance and go to Analytical Software Tools).

Handbook 135 can be downloaded from the NIST web site at: http://www.nist.bfrl.gov/oae/publications/handbooks/135.html

The latest versions of BLCC 5 and BLCC4-associated programs and uscr guides can be downloaded from the DOE/FEMP web site at:

http://www.eren.doe.gov/femp (click on icon Technical Assistance and go to Analytical Software Tools).

To request diskettes of $\mathrm{BLCC} 4$, a CD of BLCC5 and hard copies of the above publications, call the FEMP Help Desk:

Energy Efficiency and Renewablc Energy Clearing House

(800) DOE-EREC (800-363-3732) 
or write or fax your request to:

U.S. Department of Energy

Federal Energy Management Program, EE-90

1000 Independence Avenue, S.W.

Washington, DC 20585-0121

Fax: (202) 586-3000

BLCC4 may also be purchased from the following vendors:

FlowSoft

5 Oak Forest Court

Saint Charles, MO 63303-6622

(636) 922-FLOW (3569)

http://www.flowsoft.com

Energy Information Services

P.O. Box 381

St. Johnsbury, VT 05819-0381

(802) 748-5148

NIST, under the sponsorship of DOE, conducts three workshops:

The two-day Basic LCC Workshop explains the underlying theory of present-value analysis and integrates it with the FEMP criteria. The two-day Project-Oriented LCC Workshop builds on the Basic Workshop, focuses on the use of the BLCC computer programs and applies the LCC methodology to more complex issues. Further information is available from the FEMP Help Desk or the DOE/FEMP web site. The third workshop is a two-hour televised course that introduces the elements of life-cycle analysis of energy and water conservation projects. For information on registration and downlinking, contact Heather Schoonmaker, Telephone (865) 777-9869, E-mail hbs@icx.net.

FEMP-Qualified Instructors are available to conduct LCC workshops on their own account across the U.S. For a list of instructors call the Office of Applied Economics, NIST BFRL. (301) 9756134/6136 or e-mail sieglinde.fuller@nist.gov or amy.rushing@nist.gov.

Three video training films in a series entitled "Least-Cost Energy Decisions for Buildings" have been prepared by NIST. These films include "Introduction to Life-Cycle Costing," "Uncertainty and Risk." and "Choosing Economic Evaluation Methods." The video films and companion workbooks can be ordered from Video Transfer, Inc., 5709-B Arundel Avenue, Rockville, MD 20852, Telephone (301) 881-0270, Fax (301) 770-9131.

Further information on the Federal Energy Management Program can be obtained from the Federal Energy Management Program Staff, Office of the Assistant Secretary for Energy Efficiency and Renewable Energy, U.S. Department of Energy. Please direct communication to: FEMP. LI: 90. U.S. Department of Energy, 1000 Independence Avenue, SW, Washington, DC 20585. 


\section{ACKNOWLEDGMENTS}

The authors wish to thank Mr. Theodore Collins of the Federal Energy Management Program of the U.S. Department of Energy (DOE) for his continued support and direction of this work. Appreciation is extended to Susan Holte and Paul Kondis, DOE Energy Information Administration, for providing the energy price projections upon which this report is based. Thanks are also due to Stephen Petersen, who helped prepare this publication, and to J'aime Maynard for her assistance in producing this document. 


\section{CONTENTS}

Page

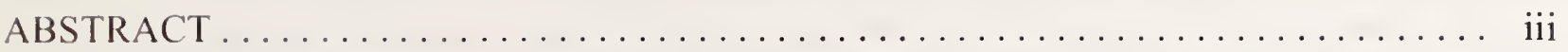

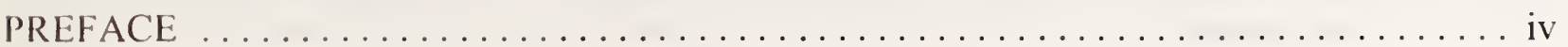

ACKNOWLEDGMENTS $\ldots \ldots \ldots \ldots \ldots \ldots \ldots \ldots \ldots \ldots \ldots$ viii

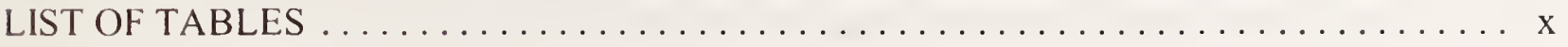

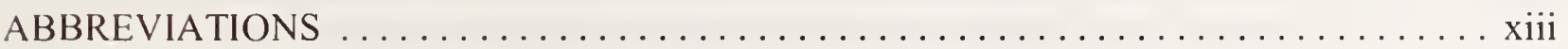

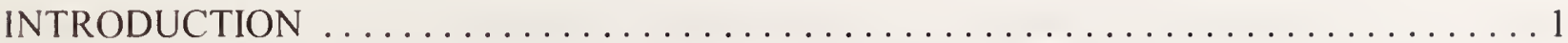

PART I: TABLES FOR FEDERAL LIFE-CYCLE COST ANALYSIS $\ldots \ldots \ldots \ldots \ldots \ldots$

A. Single Present Value and Uniform Present Value Factors for Non-Fuel Costs . . . . . 3

B. Modified Uniform Present Value Factors for Fuel Costs . . . . . . . . . . . . 11

B.1. FEMP Modified Uniform Present Value Factors . . . . . . . . . . . . . . . . 14

B.2. OMB Modified Uniform Present Value Factors $\ldots \ldots \ldots \ldots \ldots . \ldots . \ldots . . \ldots 20$

C. Projected Average Fuel Price Indices and Escalation Rates (Real) . . . . . . . . 26

PART II: ENERGY PRICE INDICES FOR PRIVATE SECTOR LCC ANALYSIS . . . . . . 43 


\section{LIST OF TABLES}

Page

A-1. SPV factors for finding the present value of future single costs (non-fuel) $\ldots \ldots 6$

A-2. UPV factors for finding the present value of future annually recurring uniform costs

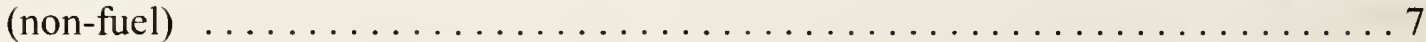

A-3a UPV* factors for finding the present value of annually recurring costs changing at at a constant escalation rate, DOE discount rate $(3.2 \%) \ldots \ldots \ldots \ldots \ldots \ldots$

A-3b UPV* factors for finding the present value of annually recurring costs changing at at a constant escalation rate, OMB short-term discount rate $(3.0 \%) \ldots \ldots \ldots$

A-3c UPV* factors for finding the present value of annually recurring costs changing at at a constant escalation rate, OMB long-term discount rate $(3.9 \%) \ldots \ldots \ldots 10$

Ba-1. FEMP UPV $V^{*}$ discount factors adjusted for fuel price escalation, by end-use sector and fuel type. Discount Rate $=3.2 \%$ (DOE). Census Region 1 (Connecticut, Maine, Massachusetts, New Hampshire, New Jersey, New York, Pennsylvania, Rhode Island,

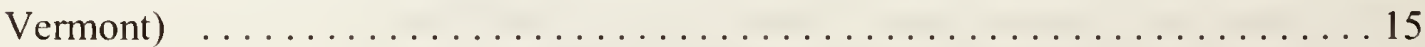

Ba-2. $\quad$ FEMP UPV discount factors adjusted for fuel price escalation, by end-use sector and fuel type. Discount Rate $=3.2 \%$ (DOE). Census Region 2 (Illinois, Indiana, Iowa, Kansas, Michigan, Minnesota, Missouri, Nebraska, North Dakota, Ohio, South Dakota, Wisconsin) . . . . . . . . . . . . . . . . . . . . 16

Ba-3. FEMP UPV discount factors adjusted for fuel price escalation, by end-use sector and fuel type. Discount Rate $=3.2 \%$ (DOE). Census Region 3 (Alabama, Arkansas, Delaware, District of Columbia, Florida, Georgia, Kentucky, Louisiana, Maryland, Mississippi, North Carolina, Oklahoma, South Carolina, Tennessee, Texas, Virginia, West Virginia) . . . . . . . . . . . . . . . . . . . . . . . . . . 17

Ba-4. FEMP UPV discount factors adjusted for fuel price escalation, by end-use sector and fuel type. Discount Rate $=3.2 \%$ (DOE). Census Region 4 (Alaska, Arizona, California, Colorado, Hawaii, Idaho, Montana, Ncvada, New Mexico, Oregon, Utah, Washington, Wyoming)

Ba-5. FEMP UPV* discount factors adjusted for fuel price escalation, by end-use sector and fuel type. Discount Rate $=3.2 \%$ (DOE). United States average . . . . . . . . . 19

Bb-1. $\quad \mathrm{OMB} U P V^{*}$ discount factors adjusted for fuel price escalation, by end-use sector and fuel type. Discount Ratc $=3.0 \%$ (ycars 1-10) and 3.9\% (ycars 11-30), (OMB Circular A-94). Census Region 1 (Connecticut, Maine, Massachusetts, New Hampshirc. New Jersey, New York, Pennsylvania, Rhode Island, Vermont) 


\section{LIST OF TABLES (continued)}

Page

Bb-2. OMB UPV ${ }^{*}$ discount factors adjusted for fuel price escalation, by end-use sector and fuel type. Discount Rate $=3.0 \%$ (years 1-10) and 3.9\% (years 11-30), (OMB Circular A-94). Census Region 2 (Illinois, Indiana, Iowa, Kansas, Michigan, Minnesota, Missouri, Nebraska, North Dakota, Ohio, South Dakota, Wisconsin) . . . . . . . 22

Bb-3. $\quad$ OMB UPV* discount factors adjusted for fuel price escalation, by end-use sector and fuel type. Discount Rate $=3.0 \%$ (years $1-10$ ) and 3.9\% (years 11-30), (OMB Circular A-94). Census Region 3 (Alabama, Arkansas, Delaware, District of Columbia, Florida. Georgia, Kentucky, Louisiana, Maryland, Mississippi, North Carolina, Oklahoma, South

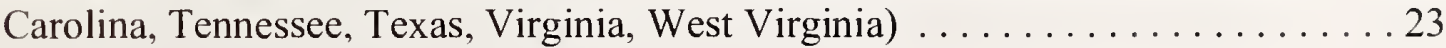

Bb-4. $\quad$ OMB UPV* discount factors adjusted for fuel price escalation, by end-use sector and fuel type. Discount Rate $=3.0 \%$ (years $1-10$ ) and 3.9\% (years 11-30), (OMB Circular A-94). Census Region 4 (Alaska, Arizona, California, Colorado, Hawaii, Idaho, Montana, Nevada, New Mexico, Oregon, Utah, Washington, Wyoming) . . . . . . 24

Bb-5. OMB UPV* discount factors adjusted for fuel price escalation, by end-use sector and fuel type. Discount Rate $=3.0 \%$ (years 1-10) and 3.9\% (years 11-30), (OMB Circular

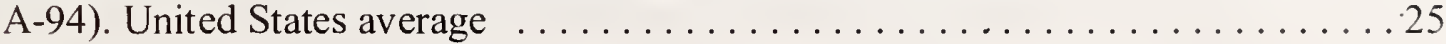

Ca-1. Projected fuel price indices (excluding general inflation) by end-use sector and fuel type. Census Region 1 (Connecticut, Maine, Massachusetts, New Hampshire, New Jersey, New York, Pennsylvania, Rhode Island, Vermont) . . . . . . . . . . . 28

Ca-2. Projected fuel price indices (excluding general inflation) by end-use sector and fuel type. Census Region 2 (Illinois, Indiana, Iowa, Kansas, Michigan, Minnesota, Missouri. Nebraska, North Dakota, Ohio, South Dakota, Wisconsin) . . . . . . . . . . 30

Ca-3. Projected fuel price indices (excluding general inflation) by end-use sector and fuel type. Census Region 3 (Alabama, Arkansas, Delaware, District of Columbia, Florida, Georgia, Kentucky, Louisiana, Maryland, Mississippi, North Carolina, Oklahoma, South Carolina, Tennessee, Texas, Virginia, West Virginia) . . . . . . . . . . . 32

Ca-4. Projected fuel price indices (excluding general inflation) by end-use sector and fucl type. Census Region 4 (Alaska, Arizona, California, Colorado, Hawaii, Idaho, Montana, Nevada, New Mexico, Oregon, Utah, Washington, Wyoming) . . . . . . . . . . 34

Ca-5. Projected fuel price indices (excluding general inflation) by end-use sector and fucl type.

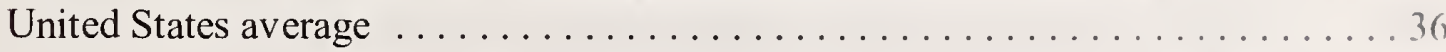

Cb-1. Projected average fuel price escalation rates (excluding general price inflation), by cnduse sector and fuel type. Census Region 1 (Connecticut, Maine, Massachusetts, New Hampshire, New Jersey, New York, Pennsylvania, Rhode Island, Vermont) . . . . 38 


\section{LIST OF TABLES (continued)}

$\mathrm{Cb}-2$. Projected average fuel price escalation rates (excluding general price inflation), by enduse sector and fuel type. Census Region 2 (Illinois, Indiana, Iowa, Kansas, Michigan, Minnesota, Missouri, Nebraska, North Dakota, Ohio, South Dakota, Wisconsin) . 39

Cb-3. Projected average fuel price escalation rates (excluding general price inflation), by enduse sector and fuel type. Census Region 3 (Alabama, Arkansas, Delaware, District of Columbia, Florida, Georgia, Kentucky, Louisiana, Maryland, Mississippi, North Carolina, Oklahoma, South Carolina, Tennessee, Texas, Virginia, West Virginia) . 40

$\mathrm{Cb}-4$. Projected average fuel price escalation rates (excluding general price inflation). by enduse sector and fuel type. Census Region 4 (Alaska, Arizona, California, Colorado, Hawaii, Idaho, Montana, Nevada, New Mexico, Oregon, Utah, Washington,

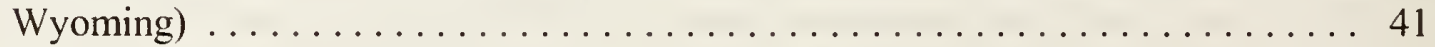

Cb-5. Projected average fuel price escalation rates (excluding general price inflation), by enduse sector and fuel type. United States average $\ldots \ldots \ldots \ldots \ldots \ldots \ldots . \ldots 42$

S-1. Projected fuel price indices with assumed general price inflation rates of 3, 4, 5, and 6 percent, by end-use sector and fuel type. Census Region 1 (Connecticut, Maine, Massachusetts, New Hampshire, New Jersey, New York, Pennsylvania, Rhode Island, Vermont) . . . . . . . . . . . . . . . . . . . . . . 45

S-2. Projected fuel price indices with assumed general price inflation rates of $3,4,5$, and 6 percent, by end-use sector and fuel type. Census Region 2 (Illinois, Indiana, lowa, Kansas, Michigan, Minnesota, Nebraska, North Dakota, Ohio, South Dakota,

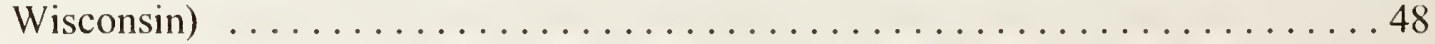

S-3. Projected fuel price indices with assumed general price inflation rates of 3, 4, 5, and 6 percent, by end-use sector and fuel type. Census Region 3 (Alabama, Arkansas, Delaware, District of Columbia, Florida. Georgia, Kentucky, Louisiana, Maryland, Mississippi, North Carolina, Oklahoma, South Carolina, Tennessee, Texas, Virginia,

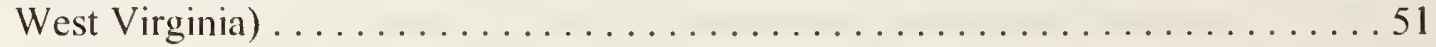

S-4. Projected fuel price indices with assumed general price inflation rates of 3, 4, 5, and 6 percent, by end-use sector and fuel typc. Ccnsus Region 4 (Alaska, Arizona, California, Colorado, Hawaii, Idaho, Montana, Nevada, New Mexico, Oregon, Utah, Washington,

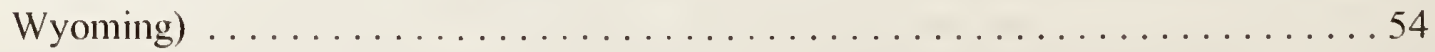

S-5. Projected fucl price indices with assumed general price inflation rates of 3, 4, 5, and 6 percent, by cnd-use scctor and fuel typc. United Statcs avcragc $\ldots \ldots \ldots \ldots 57$ 


\section{ABBREVIATIONS}

$\begin{array}{lll}\text { A } & - & \text { Annual amount } \\ \text { A }_{0} & - & \text { Annual amount at base-date prices } \\ \text { AEO2002 } & - & \text { Annual Energy Outlook 2002 (DOE-EIA publication) } \\ \text { ASTM } & - & \text { American Society for Testing and Materials } \\ \text { BLCC } & - & \text { NIST Building Life Cycle Cost computer program } \\ \text { COAL } & - & \text { Coal } \\ \text { d } & - & \text { discount rate } \\ \text { DIST } & - & \text { Distillate Oil } \\ \text { DOE } & - & \text { U.S. Department of Energy } \\ \text { e } & - & \text { price escalation rate (annual rate of price change) } \\ \text { EIA } & - & \text { Energy Information Administration (DOE) } \\ \text { ELEC } & - & \text { Electricity } \\ \text { FEMP } & - & \text { Federal Energy Management Program } \\ \text { FY } & - & \text { Fiscal Year } \\ \text { GASLN } & - & \text { Gasoline } \\ \text { LCC } & - & \text { Life-Cycle Cost } \\ \text { LPG } & - & \text { Liquefied petroleum gas } \\ \text { N } & - & \text { Number of discount periods (in years) } \\ \text { NEMS } & - & \text { National Energy Modeling System } \\ \text { NIST } & - & \text { National Institute of Standards and Technology } \\ \text { NTGAS } & - & \text { Natural Gas } \\ \text { OMB } & - & \text { Office of Management and Budget } \\ \text { RESID } & - & \text { Residual Oil } \\ \text { SPV } & - & \text { Single Present Value (factor) } \\ \text { UPV } & - & \text { Uniform Present Value (factor) } \\ \text { UPV } & - & \text { Modified Uniform Present Value (factor) }\end{array}$





\section{INTRODUCTION}

This report provides tables of present-valuc factors for use in the life-cycle cost analysis of capital investment projects for federal facilities. It also provides energy pricc indices based on Department of Encrgy (DOE) forccasts from 2002 to 2032. The factors and indices presented in this report arc useful for detcrmining the present value of future project-related costs, especially those related to operational cncrgy costs. Discount factors included in this report are based on two different federal sources: (1) the DOE discount ratc for projects related to energy conservation, renewable encrgy resources, and water conscrvation; and (2) Office of Management and Budget (OMB) discount rates from Circular A-94 for usc with most other capital investment projects in federal facilities.

The DOE discount and inflation rates for 2002 are as follows:

$\begin{array}{ll}\text { Real ratc (cxcluding general price inflation): } & 3.2 \% \\ \text { Nominal ratc (including general price inflation): } & 5.6 \% \\ \text { Projected 10-year average inflation rate: } & 2.3 \%\end{array}$

The DOE discount rate is based on long-term Treasury bond rates averaged over the 12 months prior to the preparation of this report. The nominal, or market rate, is converted to a real rate using the projected ratc of gencral price inflation (2.3\%) from the Economic Report of the President's Council of Economic Advisors, to correspond with the constant-dollar analysis approach that is used in most federal life-cyclc cost (LCC) analyses. Federal agencies and contractors to federal agencies are required by 10 CFR 436 to use the DOE discount rate when conducting LCC analyses related to encrgy conservation, rencwable cnergy resources, and water conservation projects for federal facilities.

OMB Circular A-94 on guidelines and discount rates for benefit-cost analysis of fedcral programs was cxtensively revised in October 1992. There is no longer a single OMB discount rate as in the past. OMB has specified two basic types of discount rates: (1) a discount rate for cost-effectivencss, leasc-purchasc. and related analyses; and (2) a discount rate for public investment and regulatory analyscs. Only discount rates for the first type of analyses are included in this Annual Supplement, since the primary purposc of this report is to support cost-effectiveness studies related to the design and operation of fedcral facilitics.

$\mathrm{OMB}$ discount rates for cost-effectiveness and lease-purchase studies are based on intercst rates on Treasury Notes and Bonds with maturities ranging from 3 to 30 ycars. Currently (as of January 2002) five maturities have been specifically identified by OMB, and are shown here with the corresponding real interest rate to be used as the discount rate for studies subject to OMB Circular A-94:

\begin{tabular}{|c|c|c|c|c|c|}
\hline Maturity: & 3-year & 5-year & 7-year & 10 -year & 30-ycar \\
\hline Rate: & $2.1 \%$ & $2.8 \%$ & $3.0 \%$ & $3.1 \%$ & $3.9 \%$ \\
\hline
\end{tabular}

OMB suggests that the actual discount rate for an economic analysis be interpolated from these maturities and rates, based on the study period used in the analysis. Duc to limitations on the size of this Annual Supplement, discount factors for only two of these maturitics are presented: factors for shortterm analyses (up to 10 years) based on the 7-year real rate $(3.0 \%)$, and factors for long-tcrm analyses (longer than 10 years) based on the 30 -year real rate $(3.9 \%)$. As a result, thesc discount factors are for approximation purposes only. It is suggested that the NIST Building Life Cycle Cost (BLCC) or DISCOUNT programs be used to compute the present valuc factors for the discount ratc corresponding 
to the length of the study period when approximate values are not satisfactory for the project analysis. (See preface for details on obtaining these programs.)

The energy price indices and corresponding present value factors published in this report are computed from energy price forecasts provided to NIST by the Department of Energy's Energy Information Administration (EIA). The EIA energy price forecast used in this report was the most recent available at the time that this report was prepared. A description of the methodology used by EIA to project energy prices through 2032 is included in section B of this report. DOE has not projected escalation rates for water prices to be used in the LCC analysis of water conservation projects. Water escalation rates should be obtained from the local water utility when possible.

Federal agencies and contractors to federal agencies are encouraged to seek encrgy price projections from their local utility to use in place of the DOE/EIA regional projections, especially when evaluating alternative fucl types. In such cases the NIST BLCC or DISCOUNT programs can be used to calculate appropriate "modificd uniform present value" (UPV*) factors for use in the LCC analysis of federal energy conservation or renewable resource projects. Otherwise, 10 CFR 436 requires the use of the DOE encrgy price forecasts when conducting LCC analyses of such projects. The UPV* factors for energy costs presented in this report have been precalculated with the DOE forecast data. Thus the use of these UPV* factors automatically ensurcs that the DOE forecast data have been included in the analysis.

All of the tables of discount factors contained in this report are based on real discount rates and are therefore intended for use only with cconomic analyses conducted in constant dollars (in which the purchasing power of the dollar is held constant). The encrgy pricc cscalation rates and corresponding energy price indices contained in this report are also expressed in real terms. If nominal discount rates and current dollar costs (which both include inflation) are used in the LCC analyses of federal projects, use the BLCC computer program in the "general analysis" mode.

This report uses the term "present valuc" instcad of "present worth" for the discount factors presented. The meaning of these two terms is considered to be identical for purposes of cconomic analysis. This change in terminology was made to be consistent with the terms used in the American Socicty for Testing and Matcrials (ASTM) compilation of standards on building conomics (ASTM Standards on Building Economics, Third Edition, ASTM, Philadclphia, PA, 1994.)

In all of the tables, the "cnd-of-ycar" discounting convention is used, that is, all factors and indices are computed to adjust future dollar amounts to present value from the end of the year in which they are cxpected to oceur. The factors and indices in this publication, which include cnergy price cscalation rates (c.g., UPV* factores and energy price indices), were calculated using April 1, 2002 (the date of this publication) as their base datc. However, these factors and indices can be used without adjustment for the LCC analysis of projects with otherbase dates until the relcasc of the next revision of th is publication (April 2003). Adjustment of these factors and indices for differences in the month-specific base date is not gencrally warranted duc to uncertaintics in estimating futurc cnergy prices. 


\section{PART I: TABLES FOR FEDERAL LIFE-CYCLE COST ANALYSIS}

\section{A. Single Present Value and Uniform Present Value Factors for Non-Fuel Costs}

Table A-I presents the single present value (SPV) factors for finding the present value of future nonfucl, non-annually recurring costs, such as repair and replacement costs and salvage values. The formula for finding the present value $(\mathrm{P})$ of a future cost occurring in year $\mathrm{t}\left(\mathrm{C}_{\mathrm{t}}\right)$ is the following:

$$
P=C_{t} x \frac{1}{(1+d)^{\prime}}=C_{t} \times S P V_{t},
$$

where $\mathrm{d}=$ discount rate, and

$\mathrm{t}=$ number of time periods (years) between the present time and the time the cost is incurred.

Table A-2 presents uniform present value (UPV) factors for finding the present value of future nonfucl costs recurring annually, such as routine maintenance costs. The formula for finding the present value $(\mathrm{P})$ of an annually recurring uniform cost $(\mathrm{A})$ is the following:

$$
P=A \times \frac{(1+d)^{N}-1}{d(1+d)^{N}}=A \times U P V_{N},
$$

where $\mathrm{d}=$ discount rate, and

$\mathrm{N}=$ number of time periods (years) over which A recurs.

Tables $\boldsymbol{A}-\mathbf{3}(\boldsymbol{a}, \boldsymbol{b}, \boldsymbol{c})$ present modified uniform present value (UPV*) factors for finding the present value of annually recurring non-fuel costs, such as water costs, which are expected to change from year to year at a constant rate of change (or escalation rate) over the study period. The escalation rate can be positive or negative. The formula for finding the present value $(\mathrm{P})$ of an annually recurring cost at base-date prices $\left(\mathrm{A}_{0}\right)$ changing at escalation rate $\mathrm{e}$ is the following:

$$
P=A_{0} x\left(\frac{1+e}{d-e}\right)\left[1-\left(\frac{1+e}{1+d}\right)^{N}\right]=A_{0} x U P V^{*}{ }_{N} \quad(d \neq e)
$$

or

$$
P=A_{0} \times N=A_{0} \times U P V^{*}{ }_{N} \quad(d=e),
$$

where $\mathrm{A}_{0}=$ annually recurring cost at base-date prices,

$\mathrm{d}=$ discount rate,

e = escalation rate, and

$\mathrm{N}$ = number of time periods (years) over which A recurs. 
Note: if the discount rate is expressed in real terms, i.e., net of general inflation, then the escalation rate mulst also be expressed in real terms. If the discount rate is expressed in nominal terms, i.e., including general inflation, then the escalation rate must also be expressed in nominal terms.

In tables A-1, A-2, and A-3(a,b,c) SPV, UPV, and UPV* factors are provided for both the DOE and the OMB Circular A-94 real discount rates current as of the date of this publication. The FEMP SPV, UPV, and UPV* factors were computed using the DOE discount rate. The FEMP factors are for finding the present value of future costs associated with federal energy and water conservation projects and renewable energy projects. The OMB SPV, UPV, and UPV* factors were computed using the OMB discount rate. The OMB factors are for finding the present value of future costs associated with most other federal projects (except those specifically exempted from OMB Circular A-94). The DOE and OMB discount rates used in computing these tables are real rates, exclusive of general price inflation. Thus the resulting discount factors are intended for use with future costs that are stated in constant dollars.

NOTE: We have added to table A-3a a column of UPV* factors that incorporate an escalation rate of $-2.3 \%$, the negative of the inflation rate used to calculate the DOE nominal discount rate for 2002. The UPV* factors in this column can be used to calculate present values of fixed dollar amounts when performing a constant-dollar analysis. An example might be a fixed contract payment in an ESPC project. For these fixed amounts, the assumption that in a constant-dollar analysis all cash flows change at the rate of general inflation (so that the differential escalation rate is zero) does not apply. In real terms, fixed amounts change at a differential rate equal to the negative of the inflation rate.

\section{Examples of How to Use the Factors:}

SPV (FEMP): To compute the present value of a replacement cost expected to occur in the 8 th year for an energy efficient heating system, go to Table A-1, find the 3.2\% SPV factor for year $8(0.777)$, and multiply the factor by the replacement cost as of the base date.

SPV (OMB, Short-term): To compute the present valuc of a repair cost in the 5 th year for a floor covering (non-energy related), go to Table A-1, find the $3.0 \%$ SPV factor for year $5(0.863)$. and multiply the factor by the repair cost as of the base date.

SPV (OMB, Long-term): To compute the present value of a repair cost in the 15th year for a floor covering (non-energy related), go to Tablc A-1, find the 3.9\% SPV factor for year $15(0.563)$, and multiply the factor by the repair cost as of the base date.

UPV (FEMP): To compute the present valuc of an annually recurring maintenance cost for a renewable encrgy system over 20 years, go to Table A-2, find the 3.2\% UPV factor for 20 years (14.61), and multiply the factor by the annual maintenance cost as of the basc datc.

UPV (OMB, Short-term): To compute the present value of annually recurring costs of office cleaning over 10 years (for a project not primarily related to cnergy conservation), go to Table A-2, 
find the $3.0 \%$ UPV factor for 10 years (8.53), and multiply the factor by the annual cleaning cost as of the base date.

UPV (OMB, Long-term): To compute the present value of annually recurring costs of office cleaning over 25 years (for a project not primarily related to energy conservation), got to Table A-2, find the $3.9 \%$ UPV factor for 25 years (15.79), and multiply the factor by the annual cleaning cost as of the base date.

UPV* (all): To compute the present value of annually recurring costs of water usage which are expected to increase at $2 \%$ faster than the rate of general inflation over 25 years, find the UPV* factor from table A-3 (a,b, or c as appropriate) that corresponds to $2 \%$ escalation and a 25 year study period. From table A-3a (3.2\% DOE discount rate) the corresponding UPV* factor is 21.55 . Multiply this factor by the annual water cost as computed at base year prices to determine the present value of these water costs over the entire 25 years.

UPV* (negative inflation rate): To compute the present value of an annually recurring contract payment that is fixed over a contract period of 10 years, find the UPV* factor from table A-3a that corresponds to an escalation of $-2.3 \%$ and a 10 -year time period. From table A-3a $(3.2 \%$ DOE discount rate) the corresponding UPV* factor is 7.49. Multiply this factor by the annual contract payment as of the base year to determine the present value of these contract payments over the entire 10 -year period.

NOTE: UPV factors are generally applied to costs that recur annually in substantially the same amount. Examples of such costs are routine operating and maintenance costs. UPV* factors are generally applied to costs that recur annually but change from year to year at a constant escalation rate. Examples of such costs are water usage costs when they increase from year to year. These costs usually occur every year over the service period of the building life. If there is a planning/design/construction period before the service life begins, during which these annual costs are not incurred, the appropriate UPV (or UPV*) factor for the service period is the difference between the UPV (or UPV*) factor for the entire study period and the UPV (or UPV*) factor for the planning/design/construction period. For example, if the planning/design/construction period is 3 years and the service period is 25 years, for a total study period of 28 years, the corresponding UPV factor (from Table A-2, DOE 3.2\% discount rate) is $18.31-2.82=15.49$.

For further explanation and illustration of how to use these factors, see NIST Handbook 135. 
Table A-1. SPV factors for finding the present value of future single costs (non-fuel)

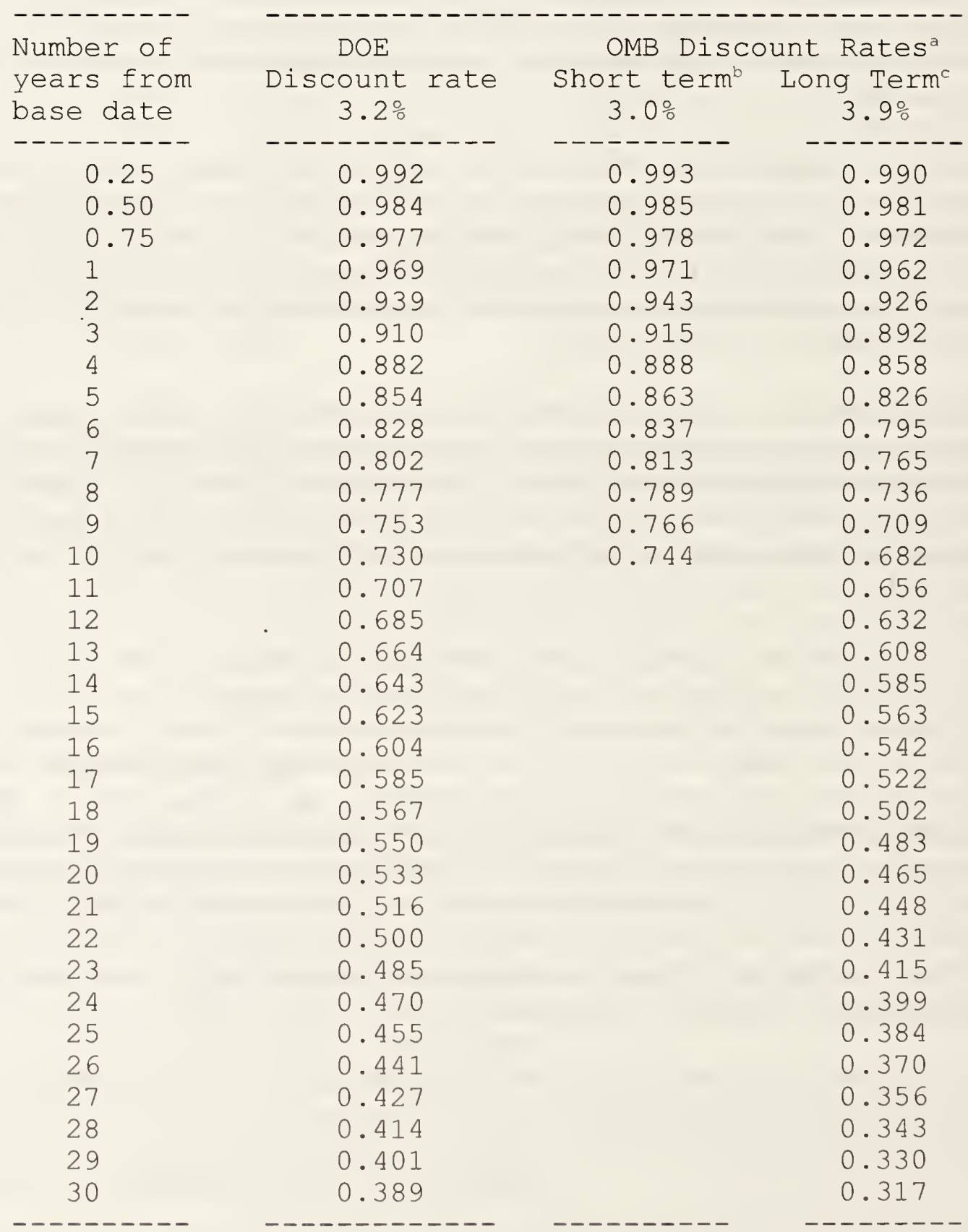

"OMB discount rates as of February 2002.

bhort-term discount rate based on OMB discount rate for 7-year study period.

${ }^{c}$ Long-term diseount rate based on OMB diseount rate for 30 -year study period. 
Table A-2. UPV factors for finding the present value of annually recurring uniform costs (non-fuel)

Uniform Present Value (UPV) Factors

\begin{tabular}{|c|c|c|c|}
\hline Number of & DOE & OMB Disc & unt Rates ${ }^{a}$ \\
\hline years from & Discount rate & Short term & Long Term \\
\hline--------- & ------------- & ---------- & --------- \\
\hline 1 & 0.97 & 0.97 & 0.96 \\
\hline 2 & 1.91 & 1.91 & 1.89 \\
\hline 3 & 2.82 & 2.83 & 2.78 \\
\hline 4 & 3.70 & 3.72 & 3.64 \\
\hline 5 & 4.55 & 4.58 & 4.46 \\
\hline 6 & 5.38 & 5.42 & 5.26 \\
\hline 7 & 6.18 & 6.23 & 6.02 \\
\hline 8 & 6.96 & 7.02 & 6.76 \\
\hline 9 & 7.71 & 7.79 & 7.47 \\
\hline 10 & 8.44 & 8.53 & 8.15 \\
\hline 11 & 9.15 & & 8.81 \\
\hline 12 & 9.84 & & 9.44 \\
\hline 13 & 10.50 & & 10.05 \\
\hline 14 & 11.14 & & 10.63 \\
\hline 15 & 11.77 & & 11.20 \\
\hline 16 & 12.37 & & 11.74 \\
\hline 17 & 12.96 & & 12.26 \\
\hline 18 & 13.52 & & 12.76 \\
\hline 19 & 14.07 & & 13.25 \\
\hline 20 & 14.61 & & 13.71 \\
\hline 21 & 15.12 & & 14.16 \\
\hline 22 & 15.62 & & 14.59 \\
\hline 23 & 16.11 & & 15.01 \\
\hline 24 & 16.58 & & 15.40 \\
\hline 25 & 17.03 & & 15.79 \\
\hline 26 & 17.47 & & 16.16 \\
\hline 27 & 17.90 & & 16.51 \\
\hline 28 & 18.31 & & 16.86 \\
\hline 29 & 18.71 & & 17.19 \\
\hline 30 & 19.10 & & 17.50 \\
\hline-------- & ----------- & --- & $-\cdots$ \\
\hline
\end{tabular}

${ }^{2} \mathrm{OMB}$ discount rates as of February 2002.

${ }^{b}$ Short-term discount rate based on OMB discount rate for 7-year study period.

${ }^{c}$ Long-term discount rate based on OMB discount rate for 30 -year study period. 


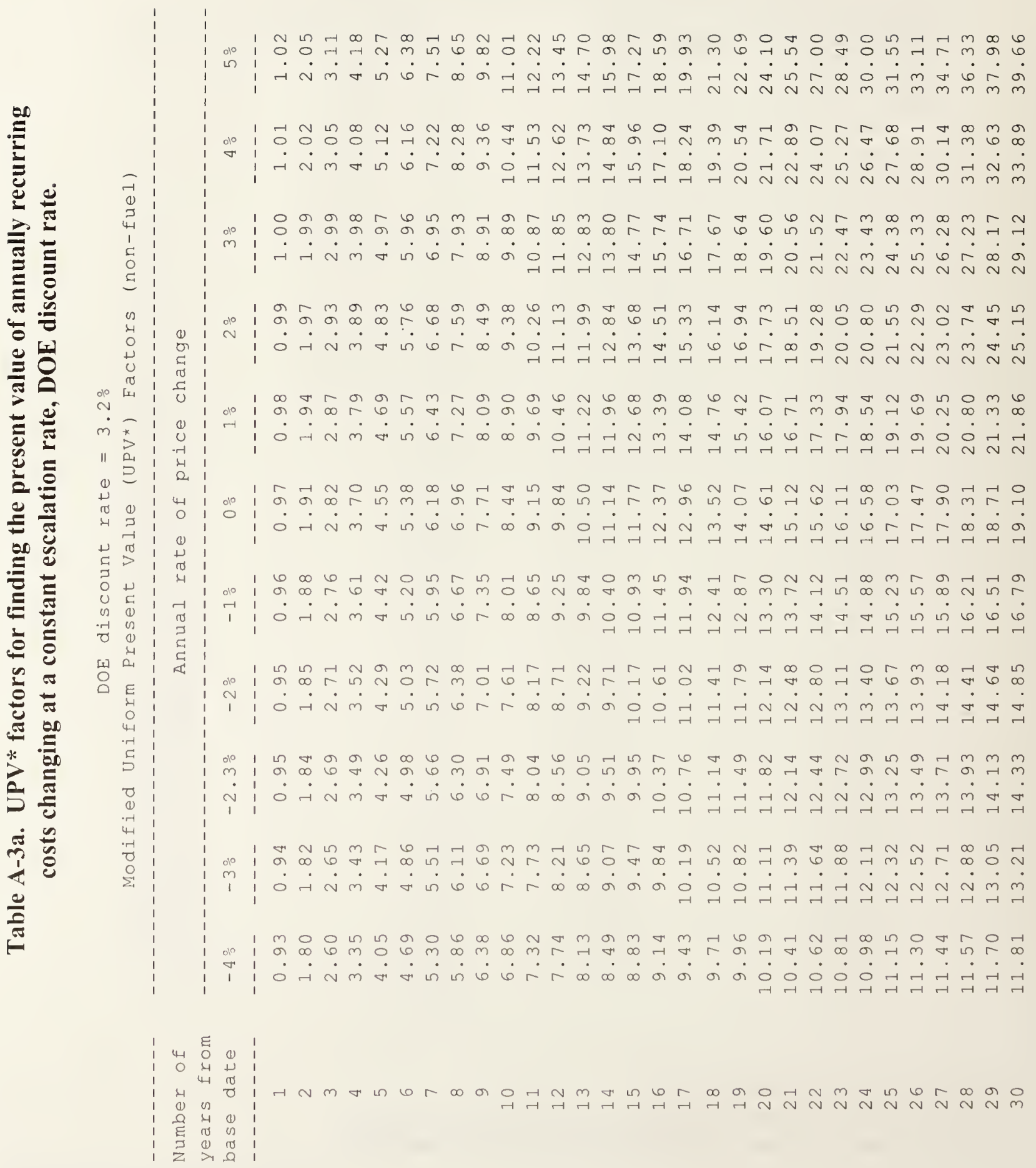




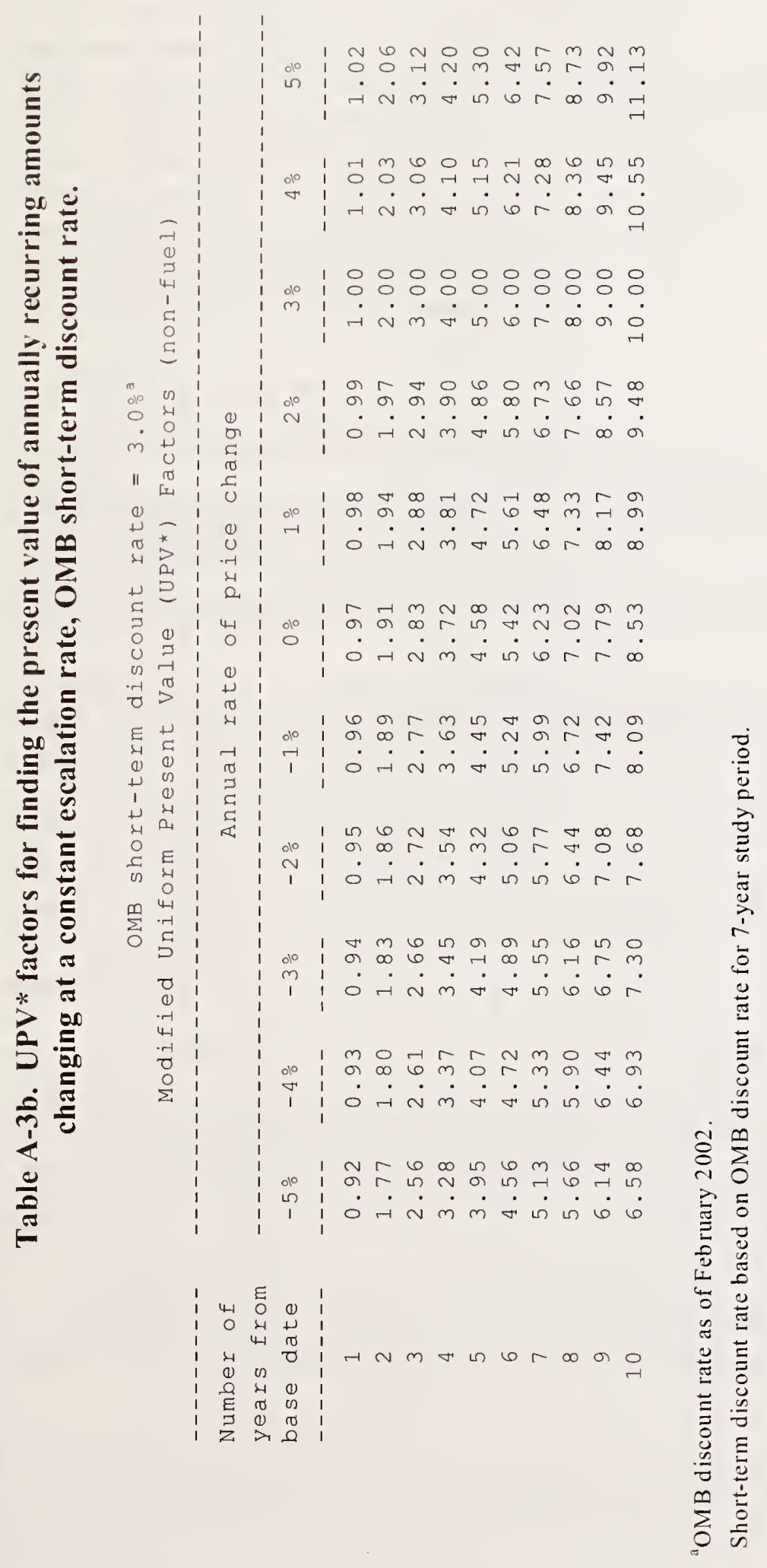




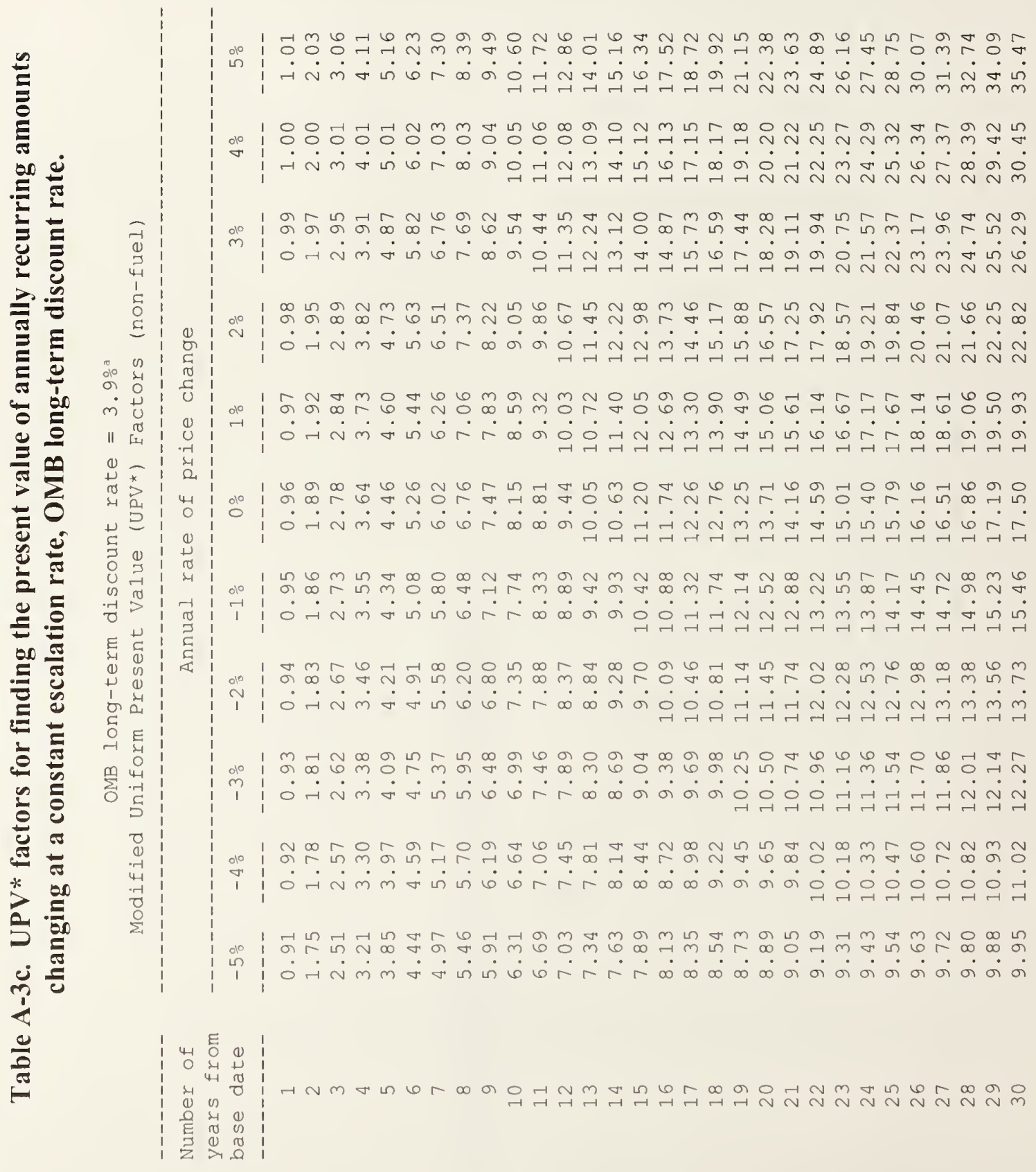




\section{B. Modified Uniform Present Value Factors for Fuel Costs}

This section presents FEMP and OMB modified uniform present value (UPV*) discount factors for calculating the present value of energy usage for federal projects. Factors are provided for the four major Ccnsus regions and for the overall United States. The factors are modified in the sense that they incorporate energy price escalation rates based on future energy prices projected by DOE for the ycars 2002-2032. There are two sets of UPV* tables: the "Ba" tables present FEMP UPV* factors based on the DOE discount rate $(3.2 \%$ real), and the "Bb" tables present OMB UPV" factors based on two OMB discount rates $(3.0 \%$ real for short-term study periods of 1 to 10 years, $3.9 \%$ real for long-term study periods of 11 to 30 years). The underlying energy price indices for the years 2002 to 2032 on which these UPV* calculations are based are shown in tables Ca-1 through Ca-5. The corresponding average energy price escalation rates for selected time intervals between 2002 and 2032 are shown in tables $\mathrm{Cb}-1$ through $\mathrm{Cb}-5$.

\section{Energy Price Projections}

The FEMP and OMB UPV* factors incorporate energy price escalation rates computed from future cnergy prices projected by the Energy Information Administration (EIA) of the U.S. Department of Energy. Energy prices through 2020 were generated by EIA using the National Energy Modeling System (NEMS) and published in the Annual Energy Outlook 2002 ${ }^{1}$ (AEO2002). At the request of FEMP, EIA extrapolated energy prices after the year 2020 from the AEO2002 data.

NEMS is an energy market model designed to project the impacts of alternative energy policies or assumptions on U.S. energy markets. NEMS produces projections of the U.S. energy future, given current laws and policies and other key assumptions, including macroeconomic indicators from Data Resources, Inc., the production policy of the Organization of Petroleum Exporting Countries, the sizc of the economically recoverable resource base for fossil fuels, and the rate of development and penetration of new technologies. NEMS balances energy supply and demands with modules representing primary fuel supply, end-use demand for four sectors, and conversion of energy by refineries and electricity generators. Macroeconomic and international oil modules reflect the impacts of energy prices, production, and consumption on world oil markets and the economy.

In order to produce price projections to 2032, EIA extrapolated the prices from the $A E O 2002$ with specific assumptions about long-term trends. To provide long-term price expectations to the post2020 projections, world oil price expectations through 2050 were calculated using assumptions of world oil supply and demand. These expectations were used as the basis for the 2032 projections of petroleum product prices, using the implied 2020 refinery markups to calculate the regional end-use prices.

The EIA energy price projections presented in this report, like those of other forccasters, are dependent on the data, methodologies, and specific assumptions used in their development. Many

\footnotetext{
${ }^{1}$ Energy Information Administration, Annual Energy Outlook 2002, DOE/EIA-0383(2002), December 2001
} 
of the assumptions concerning the future cannot be known with any degree of certainty. Thus, the projections are not statements of what will happen, but what might happen given the particular assumptions and methodologies used. Although EIA has endeavored to make these forecasts as objective, reliable, and useful as possible, these projections should serve as an adjunct to, not a substitute for, the analytical process. The $A E O 2002$ was prepared by EIA as required under statute by federal legislation. The price projections to 2032 were prepared in accordance with a Service Request from the Federal Energy Management Program.

\section{UPV* Calculation Method}

The formula for finding the present value $(\mathrm{P})$ of future energy costs or savings is the following:

$$
P=A_{o} \times \sum_{t=1}^{N} \frac{I_{(2002+t)}}{(1+d)^{t}}=A_{o} x U P V_{N}^{*},
$$

where $\mathrm{A}_{\mathrm{o}} \quad=$ annual cost of energy as of the base date (April 1, 2002);

$\mathrm{t}=$ index used to designate the year of energy usage;

$\mathrm{N} \quad=$ number of periods, e.g., years, over which energy costs or savings accrue;

$\mathrm{I}_{(2002+\mathrm{t})}=$ projected average fuel price index ${ }^{2}$ given in Tables $\mathrm{Ca}-\mathrm{I}$ through $\mathrm{Ca}-5$ for the year $2002+\mathrm{t}$ (where $\left.\mathrm{I}_{2002}=1.00\right)$; and

$\mathrm{d}=$ the real discount rate.

This formula is based on end-of-year energy prices and end-of-year discounting. Note that annual energy costs as of the base date of the LCC analysis ( $\mathrm{A}_{0}$, to be supplied by the analyst) should reflect the current energy price schedule as of that date, which may not be the same as the energy price itself on that date. ${ }^{3}$ That is, the annual energy cost should reflect summer-winter rate differences, time-ofuse rates, block rates considerations, and demand charges (as appropriate) anticipated to be in effect that year. If energy and demand costs are calculated separately (as is sometimes done for electricity), the UPV* factor should be applied to both costs.

The data in the tablẹs that follow are reported for the four Census regions and the U.S. average. Figure B-1 presents a map showing the states corresponding to the four Census regions. The Census regions do not include American Samoa, Canal Zone, Guam, Puerto Rico, Trust Territory of the Pacific Islands, or the Virgin Islands. Analysts of federal projects in these areas should use data that are "reasonable under the circumstances," and may refer to the tables with U.S. average data for guidance.

\footnotetext{
${ }^{2}$ Forgreater preeision, the UPV* factors reported in the Ba and Bb tables were eomputed using the unrounded form of the indices given in Tables $\mathrm{Ca}-1$ through $\mathrm{Ca}-5$.

${ }^{3}$ While the UPV* factors provided in this publieation were eomputed using energy price indices that correspond to energy prices as of $\Lambda$ pril 1 in the current and future years, the analyst is encouraged to use for determining $\Lambda_{0}$ the energy priees prevailing as of the base date of the LCC analysis for the project evaluated.
} 


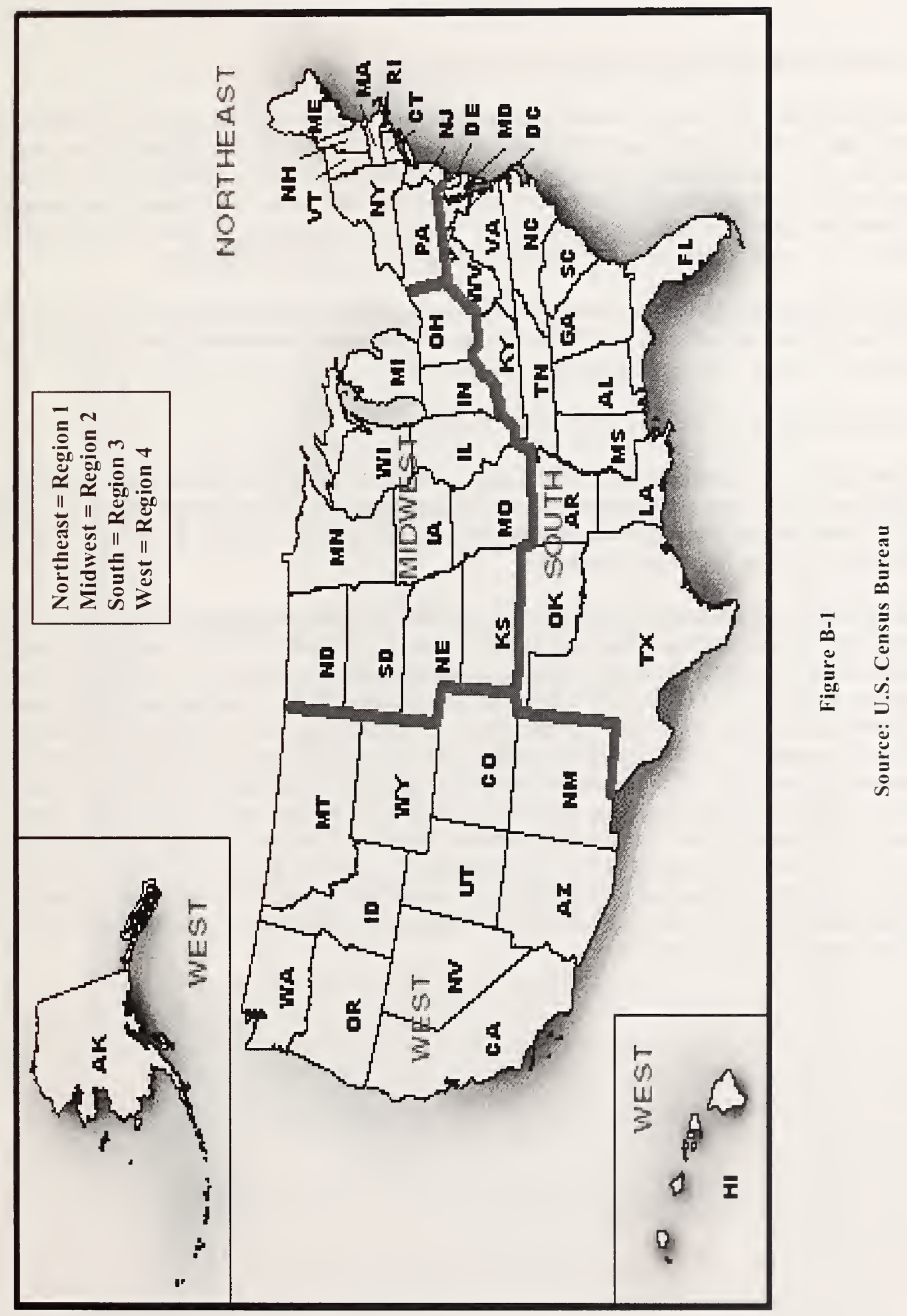




\section{B.1.FEMP Modified Uniform Present Value Factors}

The FEMP Modified Uniform Present Value (FEMP UPV*) factors presented in the "Ba" tables, based on the current DOE discount rate $(3.2 \%)$, are for calculating the present value of energy costs or savings accruing over 1 to 25 years and are to be used in life-cycle cost analyses of federal energy conservation and renewable energy projects. Factors are reported in the "Ba" tables for 30 years to accommodate a planning/design/construction period of up to 5 years. (See "Examples of How to Use FEMP UPV" Factors" below for instructions on use with planning/design/construction periods.)

These factors apply only to annual energy usage or energy savings that are assumed to be the same each year over the service period. The NIST BLCC computer program can compute the present value of energy usage and savings which are not the same in each year.

\section{Examples of How to Use the FEMP UPV* Factors:}

FEMP UPV*, no planning/design/construction period: To compute the present value of heating with natural gas over 25 years in a federal office building in New Mexico, go to Table Ba-4, find the FEMP $\mathrm{UPV}^{*}$ factor for commercial natural gas for 25 years (16.98), and multiply this factor by the annual heating cost at base-date natural gas prices.

FEMP UPV*, with planning/design/construction period: To compute a present value factor for a service period following a planning/design/construction period (1) find the FEMP UPV* factor for the combined length of the planning/design/construction period and the service period (not to exceed 30 years), and (2) subtract from (1) the FEMP UPV* factor for the planning/design/ construction period alone. The difference is the FEMP UPV* factor for the years over which energy costs or savings actually accrue. For example, suppose a new federal office building in New York is being evaluated with several energy conserving design options. It is expected to have a planning/design/construction period of 5 years, after which it will be occupied for at least 25 years. To compute the present value of natural gas costs over 25 years of occupancy, go to Table Ba- 1 and find the FEMP UPV* factors for commercial natural gas for 5 years (4.42) and for 30 years (19.57). The difference (15.15) is the FEMP UPV* factor for natural gas costs over 25 years, beginning 5 years after the base date. Multiply 15.15 by the annual natural gas cost at base-date prices (not occupancy-date prices) to calculate the present value of natural gas costs over the entire 25-year occupancy period. 
z 1 - $N$ m

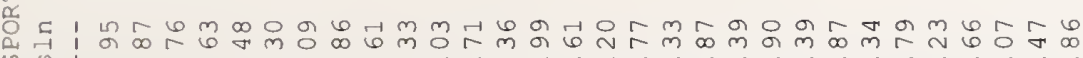

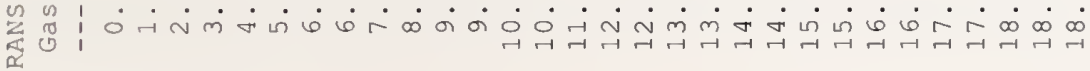

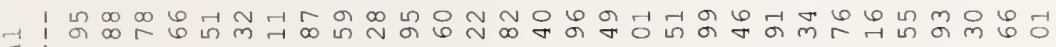

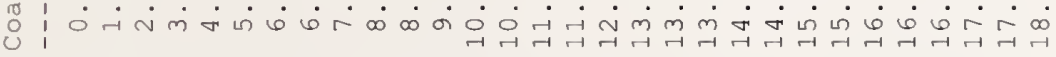

ॠ 군

○ं ग न न

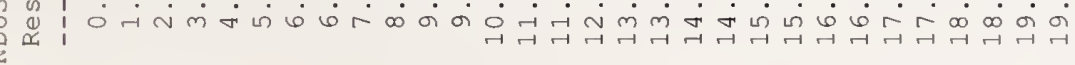

।

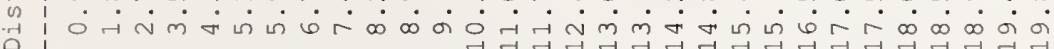
৩| |

$\rightarrow \mid$ gn

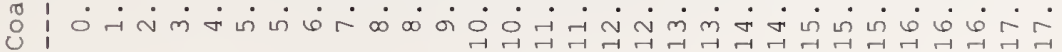
m 艺

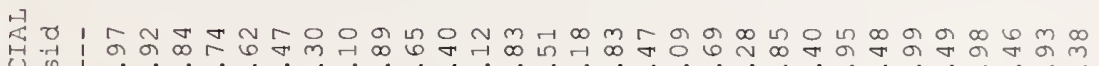

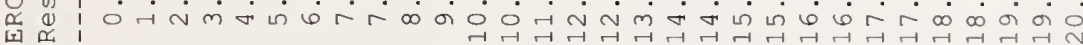
$\sum_{0}$

m N -

ง

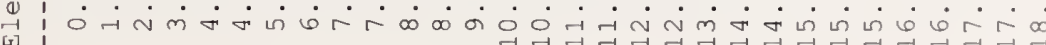

"

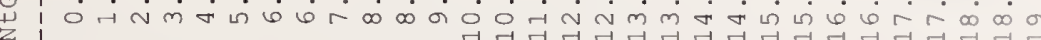

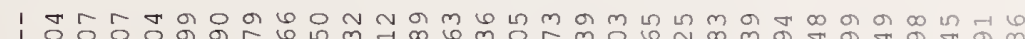
灵然

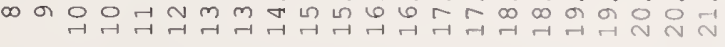

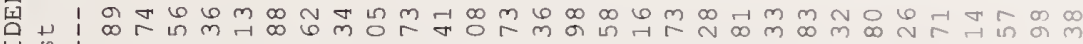

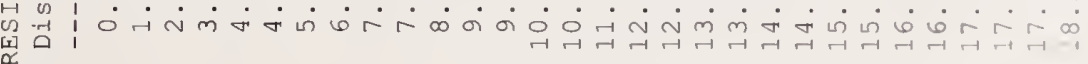

0

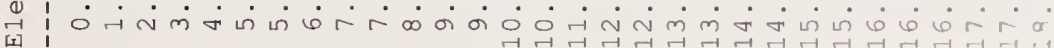

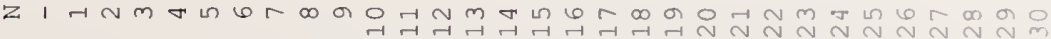




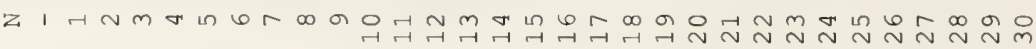

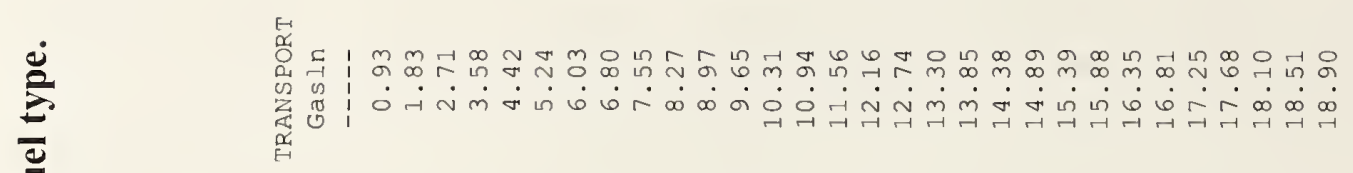

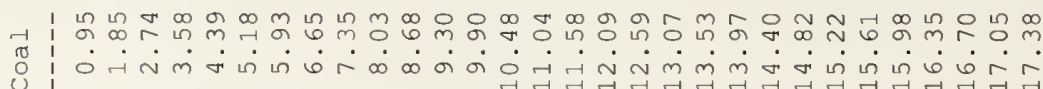

"

艺 实

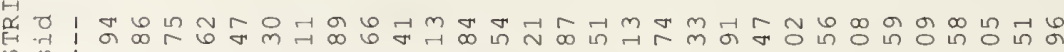

ڤ人

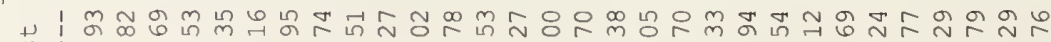
a

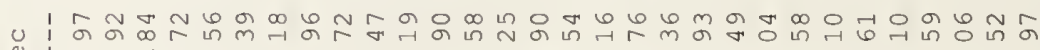

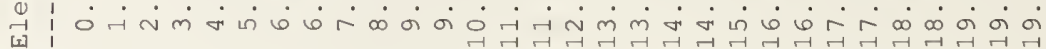

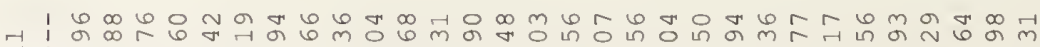
0 ठ

需 艺

荷 艺

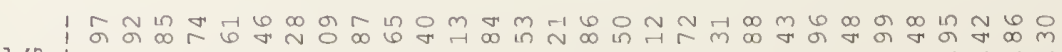
崖岁 ⿶凵 占

u t

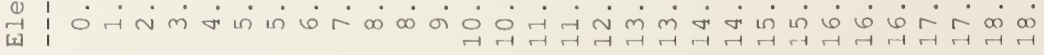

Z 1 - $N$ m 


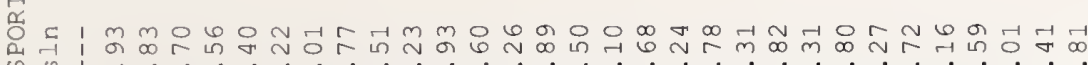
娄 窃

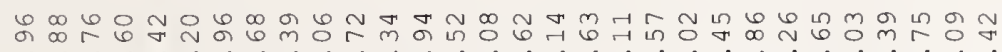

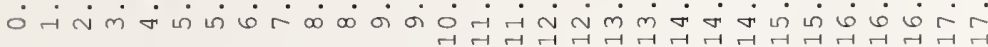

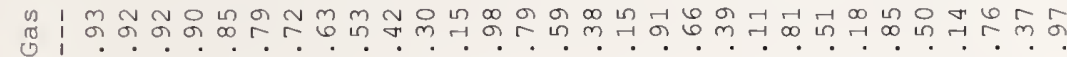
学完

㡙 客芴

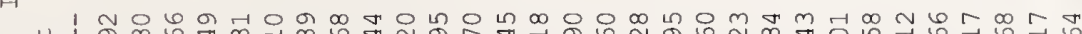

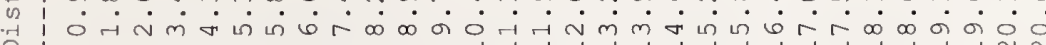

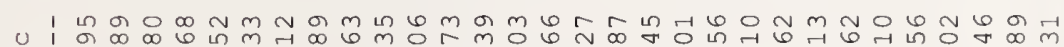

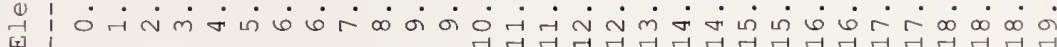

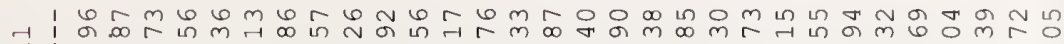

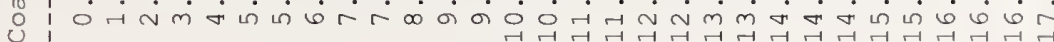

n) 艺

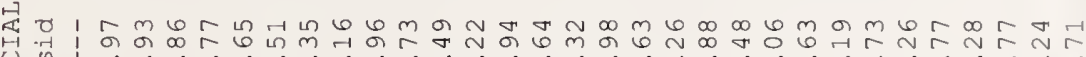

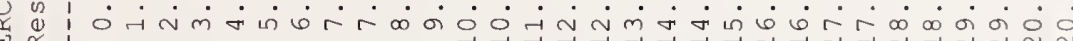

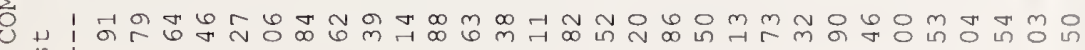

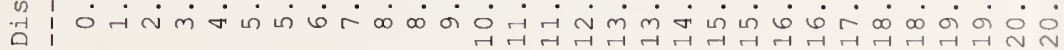

u

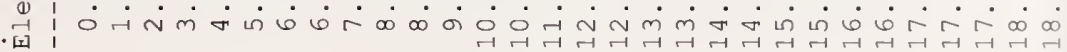

1) 艺

궁유

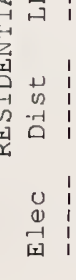

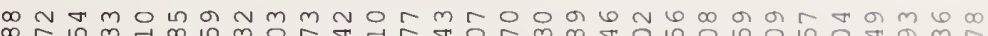

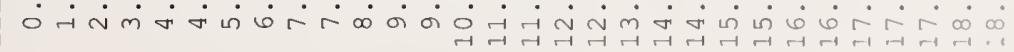

Tा

హ

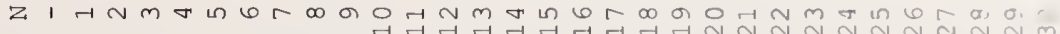


z 1 ᄀ

范

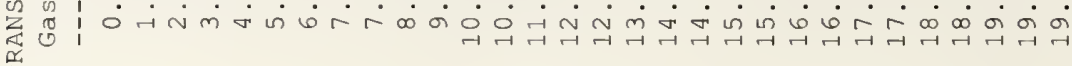
朂

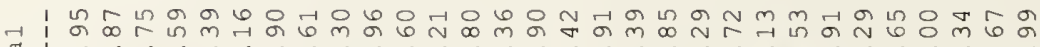

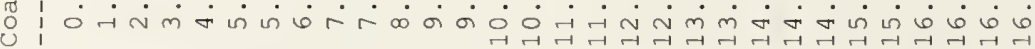

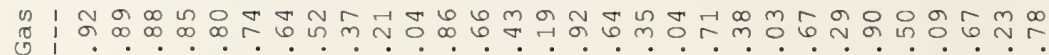

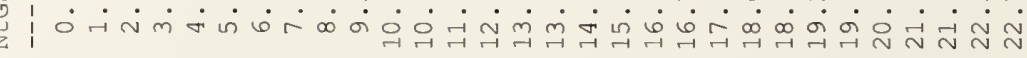

붑

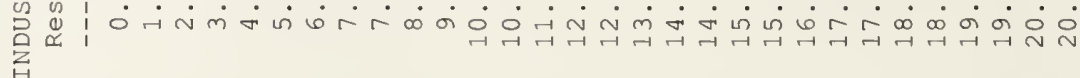

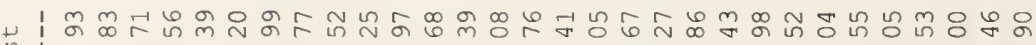

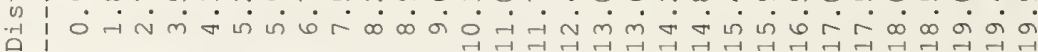

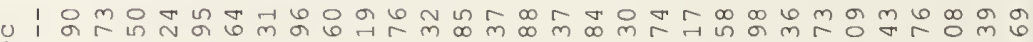

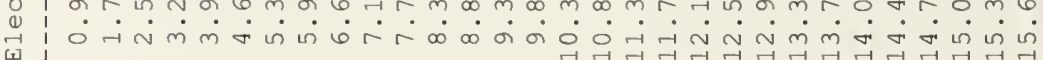

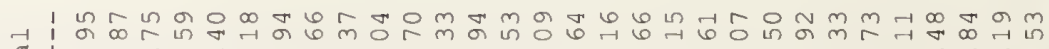
ठ అ 艺 ठ

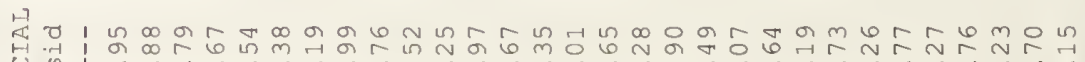

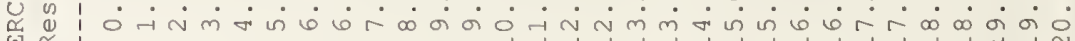
$\sum^{3}$

ठ․ -

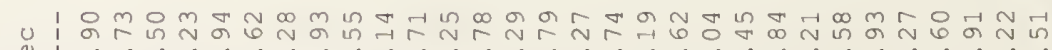
ज位

") 落

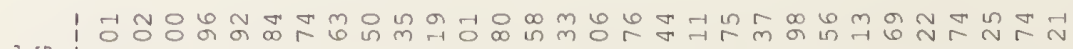

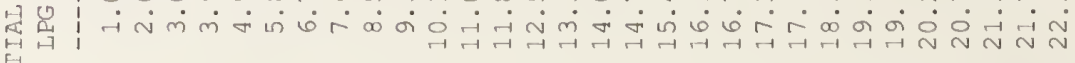
岃 嵌| u|

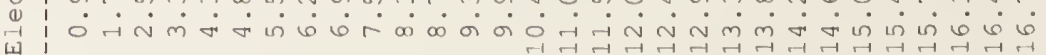


z I

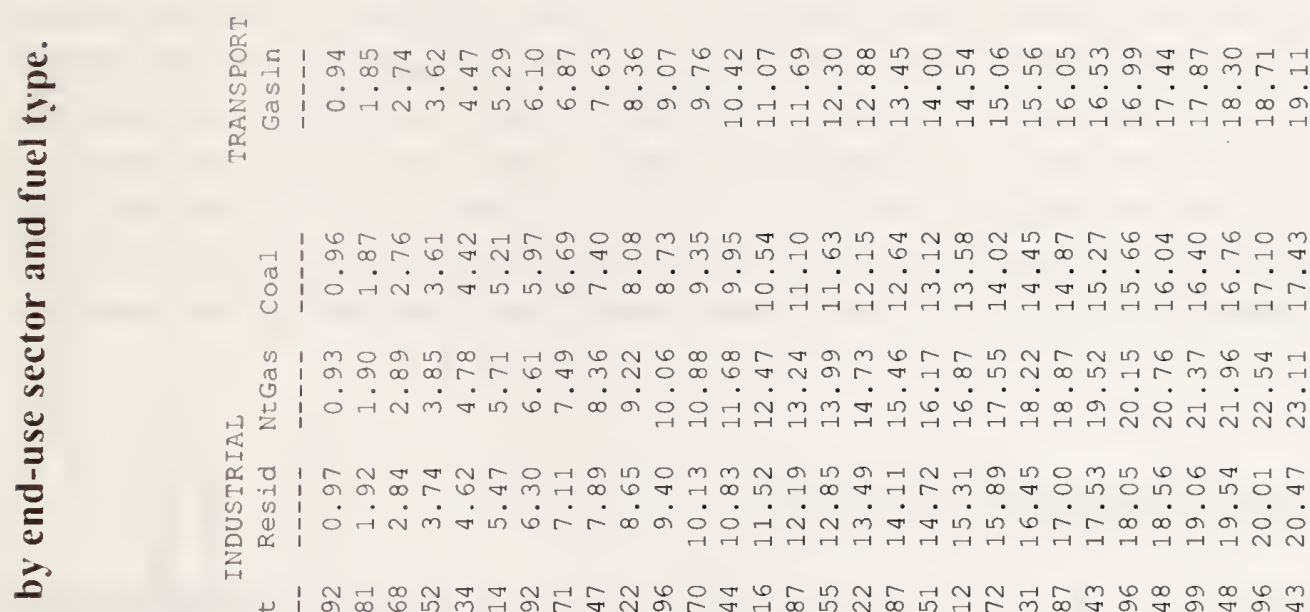

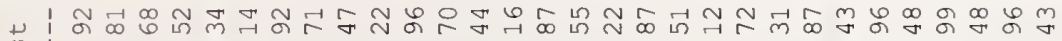

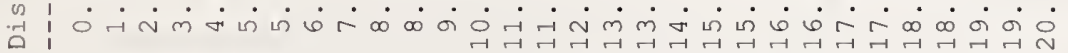

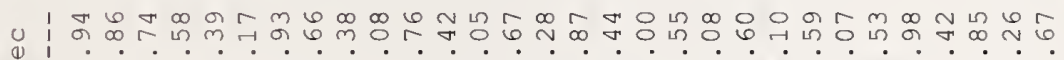
I)

개하

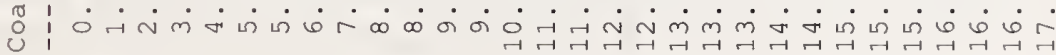
m

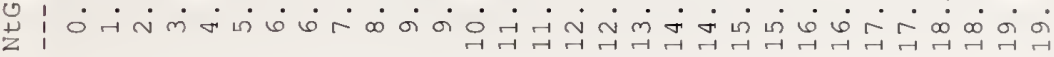
存

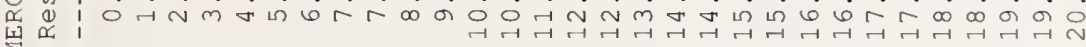
结

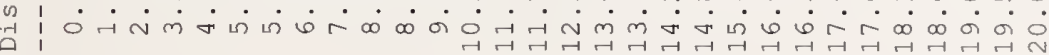
u II

๒ 艺

|유유 晨嵌 넘

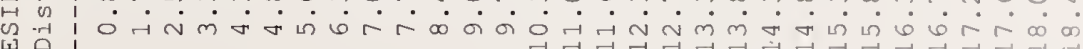
灰

บ 崝 z 1 - 


\section{B.2. OMB Modified Uniform Present Value Factors}

The OMB Modified Uniform Present Value (OMB UPV*) factors presented in the "Bb" tables, based on the current OMB discount rates ( $3.0 \%$ short term and $3.9 \%$ long term), are for calculating the present value of energy costs accruing over 1 to 30 years when conducting a life-cycle cost analysis of a federal project which is not explicitly related to energy or water conservation or renewable resources. Factors are reported in the "Bb" tables for 30 years. These factors apply only to annual energy usage that is assumed to be the same each year over the service period. The NIST BLCC computer program can compute the present value of energy usage and savings that are not the same in each year.

\section{Examples of How to Use the OMB UPV* Factors:}

OMB UPV* (OMB discount rate): To compute the present value over 30 years of electricity costs associated with the occupancy of a federal office building in Ohio (where energy conservation is not a specific consideration in the LCC analysis), go to Table Bb-2, find the OMB UPV* factor for commercial electricity for 30 years (17.38), and multiply this factor by the annual electricity cost in base-date dollars.

NOTE: Because the discount rate used to calculate the $\mathrm{Bb}$ tables (OMB discount rate) is usually different for years 1 to 10 than for years 11 to 30 , these factors cannot be used with a planning/ design/construction period as shown above for the Ba tables (DOE discount rate). Use the BLCC or DISCOUNT computer program for this purpose. For further explanation of the use of UPV* factors, see NIST Handbook 135. 


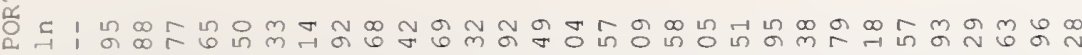

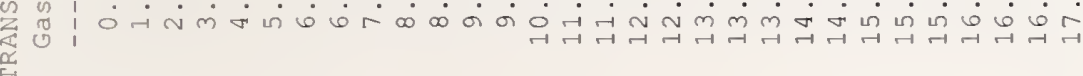
舀

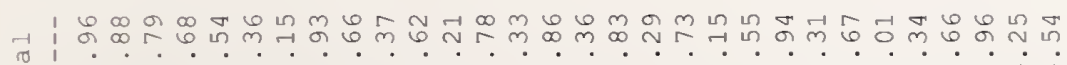
0 ठ

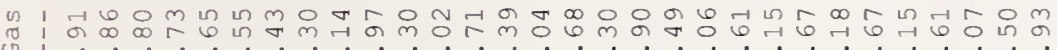
更

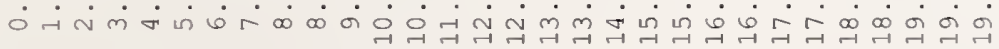
ळ ठ तं ㄴ -

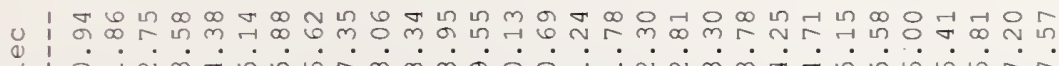
ज|

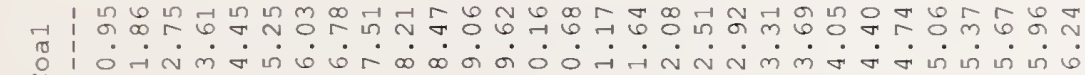
ठ m

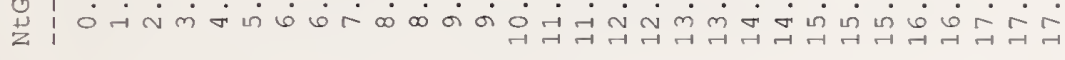
进 담

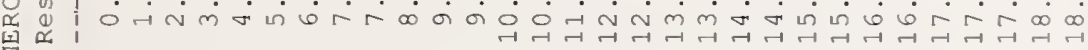
$\sum_{0}$

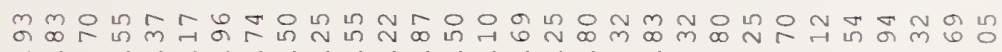
u

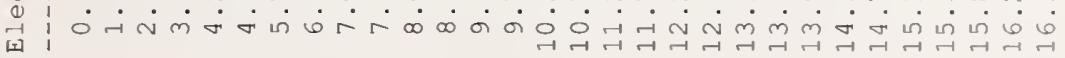

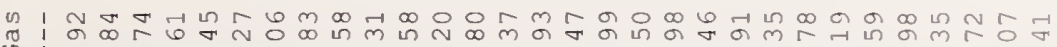
U ठ

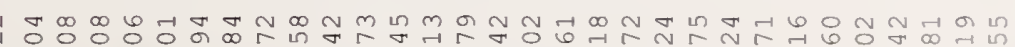
定 $z$

の O 퐁

भुm

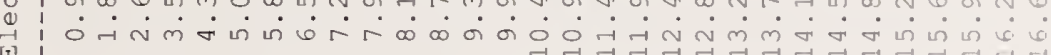
z 1 - $N$ m 


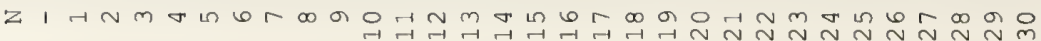
起

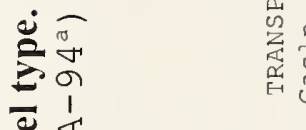

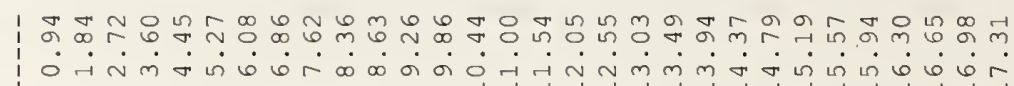

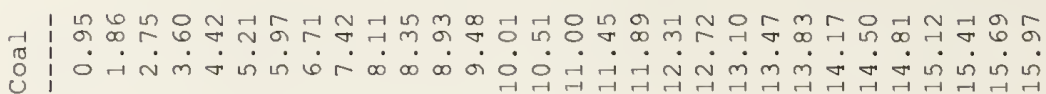

ज)

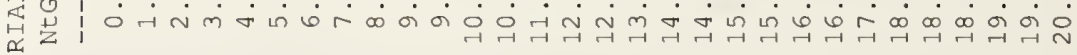
E

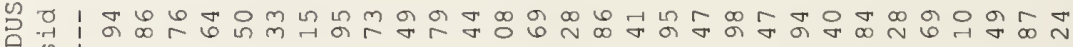

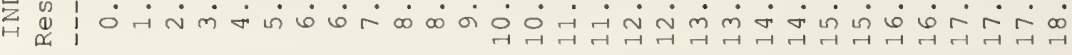

ㄴ

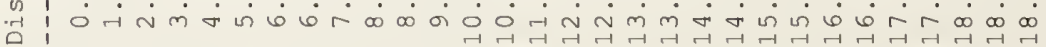

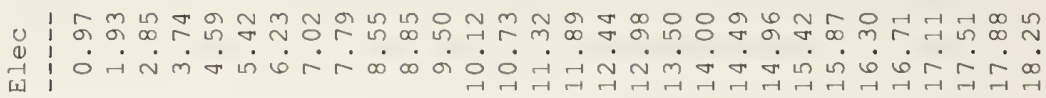

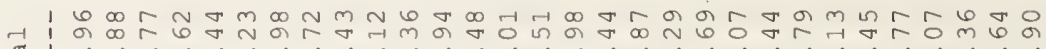
o

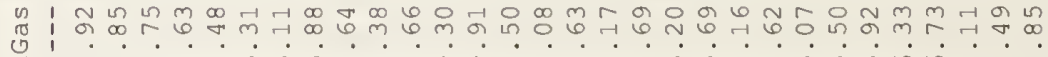
是艺

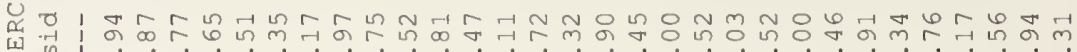

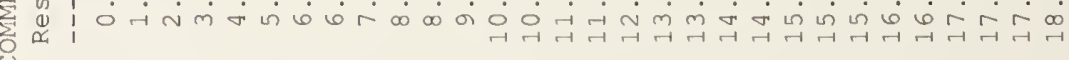

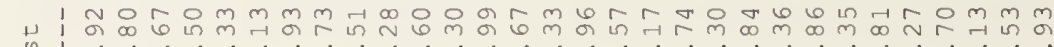
n u ने नुळ w

n J 当

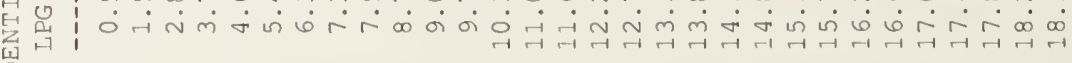
배 ब u w 
z 1 न

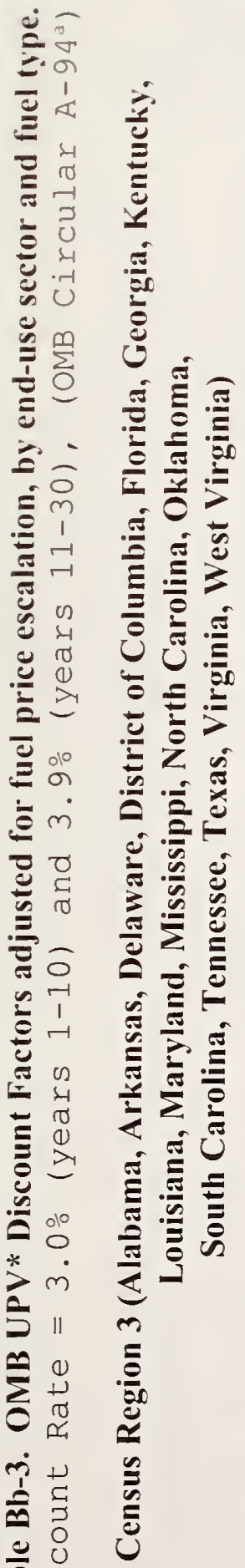

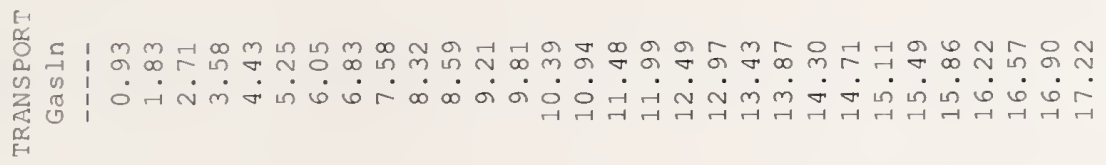

ᄀ|

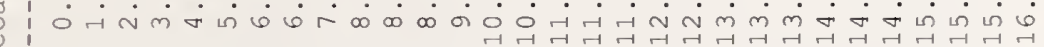

n 定艺

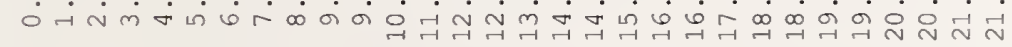

㨁

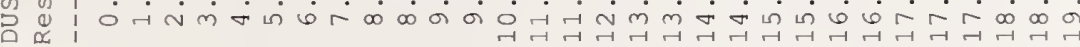

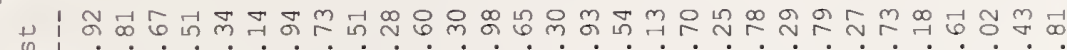
a 0| 이 ज ठ

ન

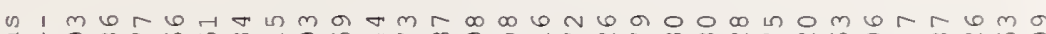
0

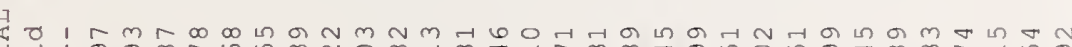
द्य

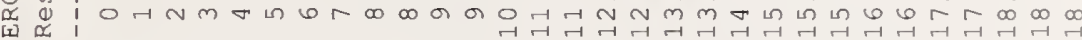
$\sum^{\infty}$

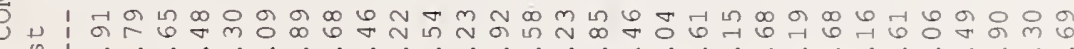
-

u| -

"

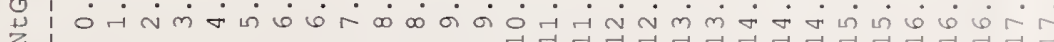

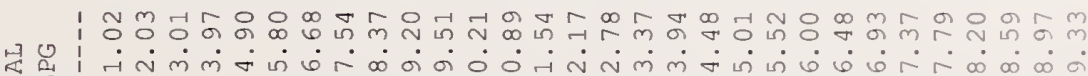
盾嵌 車

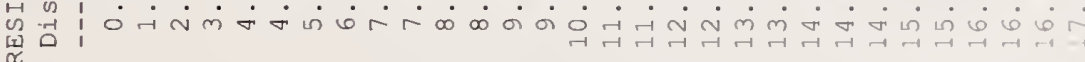

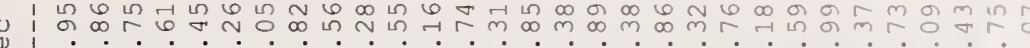

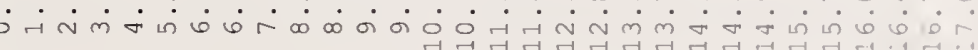

z 1 - $N$ m 
z 1 - $N$ m

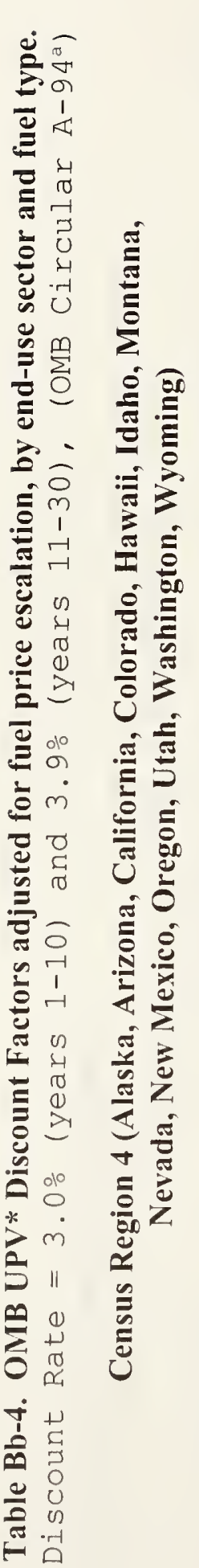

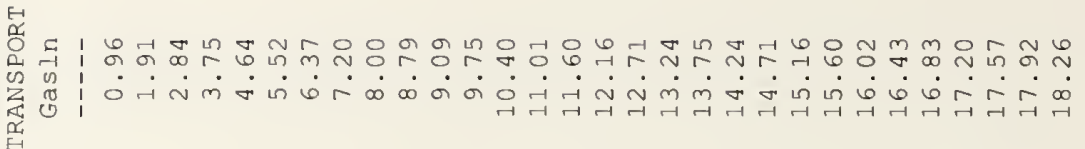

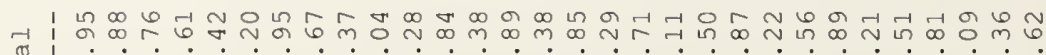
ठ

m 是艺

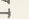

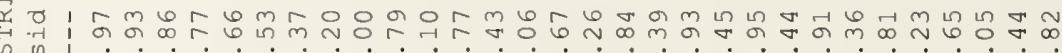

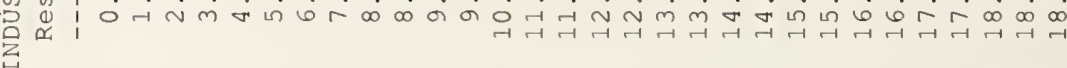

ㄴ

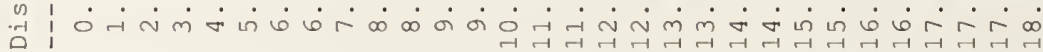
ง $\rightarrow$ o

$\rightarrow \mid$ 요 ठ

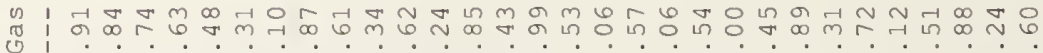
艺 进子 w Uㄴ

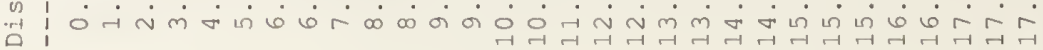
ง 윰 (1)

") \ |

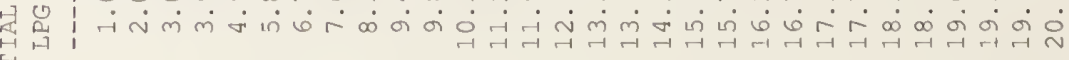

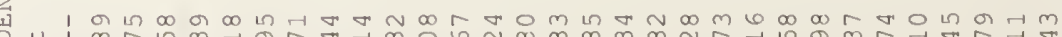

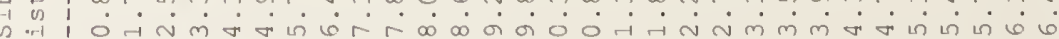
压

u| (1)

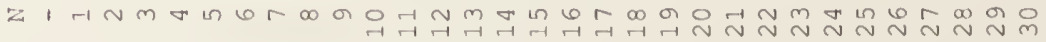


z 1 - $N$ m

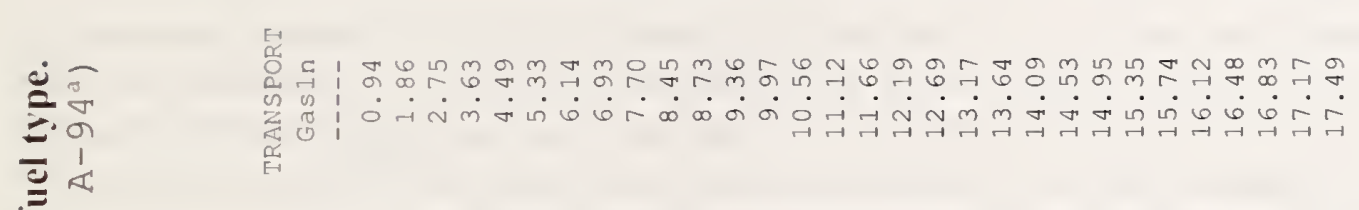

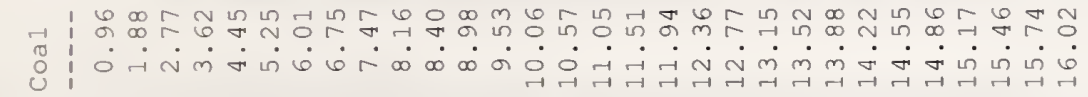

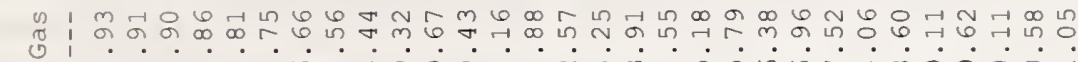
突茫

艺 ठंतं

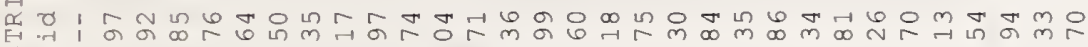

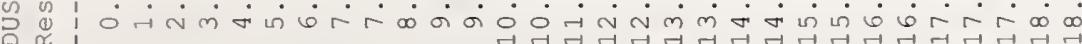
学

ㄴ 0

৩ ज ठ

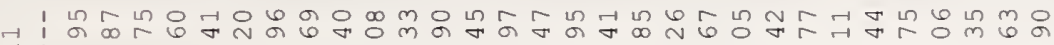
0 ठ

m 艺 0ंत் 䓠 番

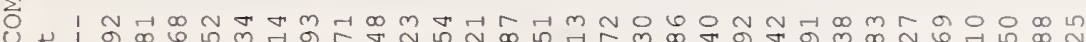
U

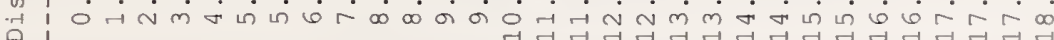
ט| 牙

(5) 艺

- 지의 ज्ञा

z 1 ᄀ 


\section{Projected Average Fuel Price Indices and Escalation Rates (Real)}

Tables $\mathbf{C a}-1$ through $\mathbf{C a}-5$ present projected fuel price indices for the four Census regions and for the United States. These indices, when multiplied by annual energy costs computed at base-date prices (i.e., as of April 1, 2002), provide estimates of future-year costs (also as of April 1) in constant base-date dollars. Constant-dollar cost estimates are needed when discounting is performed with a real discount rate (i.e., a rate that does not include general price inflation).

These indices were used in the calculation of the UPV* factors for energy prices in the $\mathrm{Ba}$ and $\mathrm{Bb}$ tables in this publication. While they are based on April 1 energy prices to maintain consistency in the computation of these UPV* factors, the level of precision implied here is not required for most LCC analyses. That is, the analyst need not calibrate base-year energy prices precisely to April 1, 2002 levels to use these indices (or the corresponding UPV* factors); instead, the analyst should use current price levels as of the base-date of the LCC analysis, regardless of the time of the year that the study is undertaken.

\section{Example of How to Use the Indices:}

To estimate the price of industrial coal in 2007 in Connecticut (in constant 2002 dollars), go to Table $\mathrm{Ca}-1$, find the year 2007 index for industrial coal (0.99), and multiply by the price for industrial coal in Connecticut in 2002.

For further explanation of how to use these tables, see NIST Handbook 135.

Tables $\boldsymbol{C b}-1$ through $\boldsymbol{C b}-5$ present the projected average fuel price escalation rates (percentage change compounded annually) for selected periods from 2002 to 2032 for the four Census regions and for the overall United States. Note that these are real rates exclusive of general price inflation. Their use results in prices expressed in constant dollars.

The average fuel escalation rates consolidate the information provided by the indices in the $\mathrm{Ca}$ tables so that trends in projected price changes can be seen at a glance. They are provided primarily to accommodate computer programs (such as BLCC) which require price escalation rates as inputs.

Unless there is a compelling reason to use escalation rates, it is recommended that you use the indices in the $\mathrm{Ca}$ tables when you need estimates of future-year energy prices, since the indices include year-to-year information rather than averages over a number of years.

\section{Example of How to Use the Escalation Rates:}

To estimate the unit price of residential natural gas at the end of $2012\left(\mathrm{p}_{12}\right)$ in Wyoming using the DOE energy price escalation rates, go to Table Cb-4 and find the 2002-2007 and the 2007-2012 esealation rates for residential natural gas $(-0.3 \%$ for 5 years and $-0.3 \%$ for 5 years, respectively). Enter these values and the unit price of residential natural gas in Wyoming in $2002\left(\mathrm{p}_{12}\right)$ into the following formula. Then solve for the 2012 energy price (stated in 2002 dollars): 


$$
\begin{aligned}
p_{12} & =p_{02} x\left(1+e_{1}\right)^{k_{1}} x\left(1+e_{2}\right)^{k_{2}} \\
& =p_{02} x(1-0.003)^{5} \times(1-0.003)^{5} \\
& =p_{02} \times 0.9704
\end{aligned}
$$

where $p_{y}=\quad$ Price at end of year $y$;

$\mathrm{e}_{\mathrm{i}}=$ Annual compound escalation rate for period $\mathrm{i}$ from the $\mathrm{Cb}$ tables (in decimal form); and

$\mathrm{k}_{1}=\quad$ Number of years over which escalation rate $\mathrm{e}_{\mathrm{i}}$ occurs.

Note that the compounded escalation rate factor $(0.9704)$ corresponds to the fuel price index in region 4, residential natural gas, for the year 2012 in table Ca-4 (0.97).

The data in the tables that follow are reported for the four Census regions and the U.S. average. Figure B-1 on page 13 presents a map showing the states corresponding to the four Census regions. The Census regions do not include American Samoa, Canal Zone, Guam, Puerto Rico, Trust Territory of the Pacific Islands, or the Virgin Islands. Analysts of federal projects in these areas should use data which are "reasonable under the circumstances," and may refer to the tables with U.S. average data for guidance. 


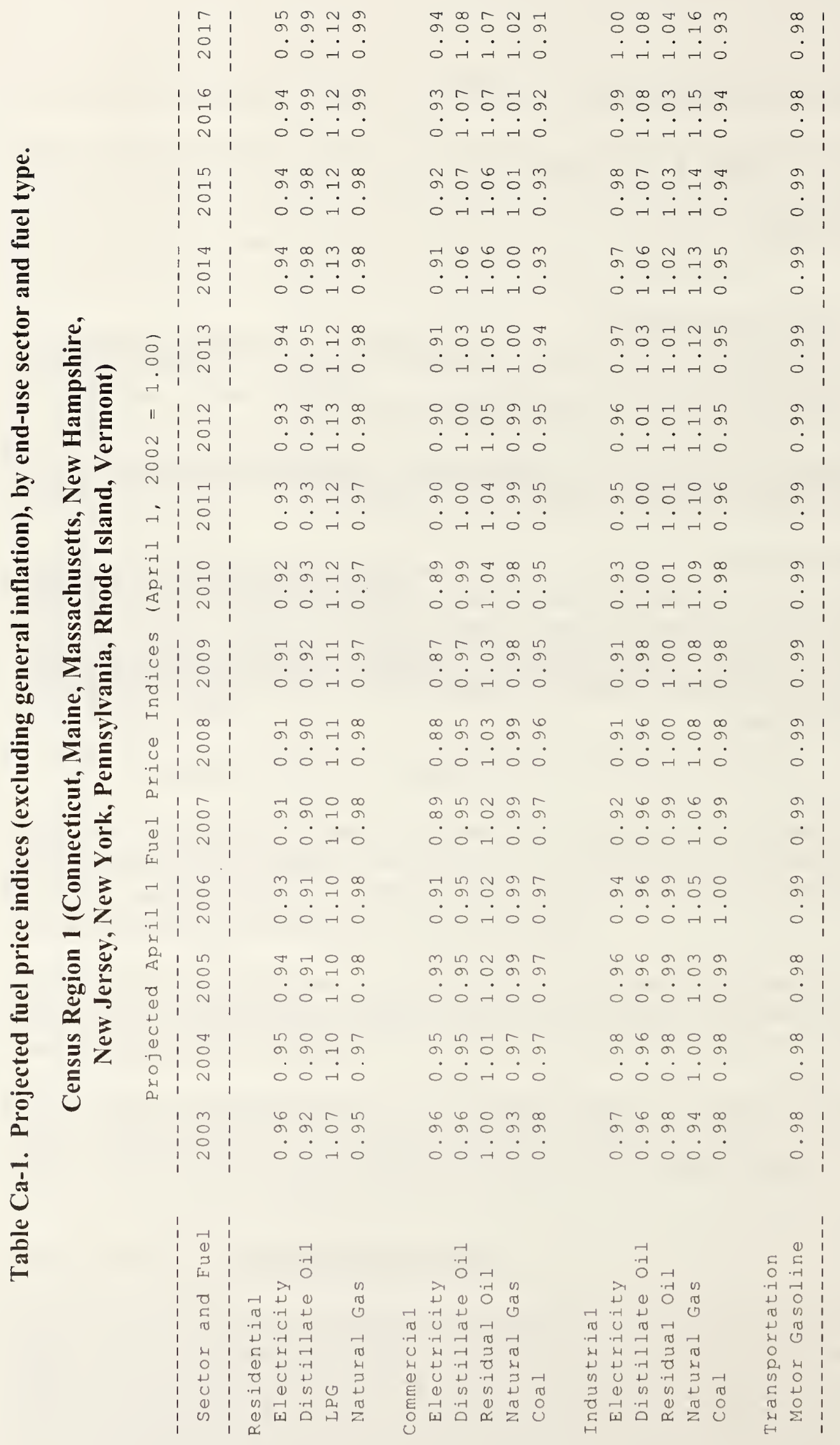




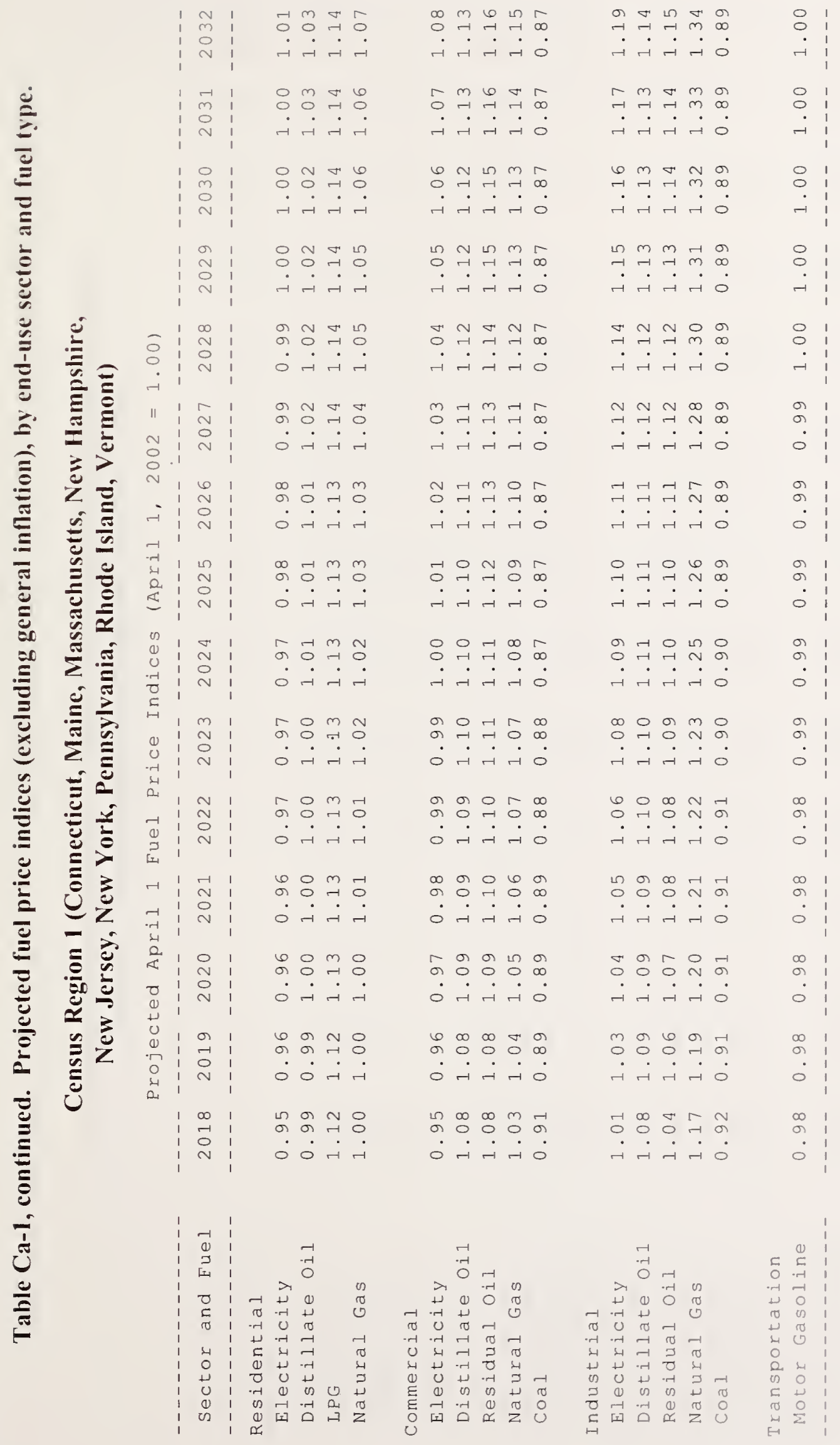




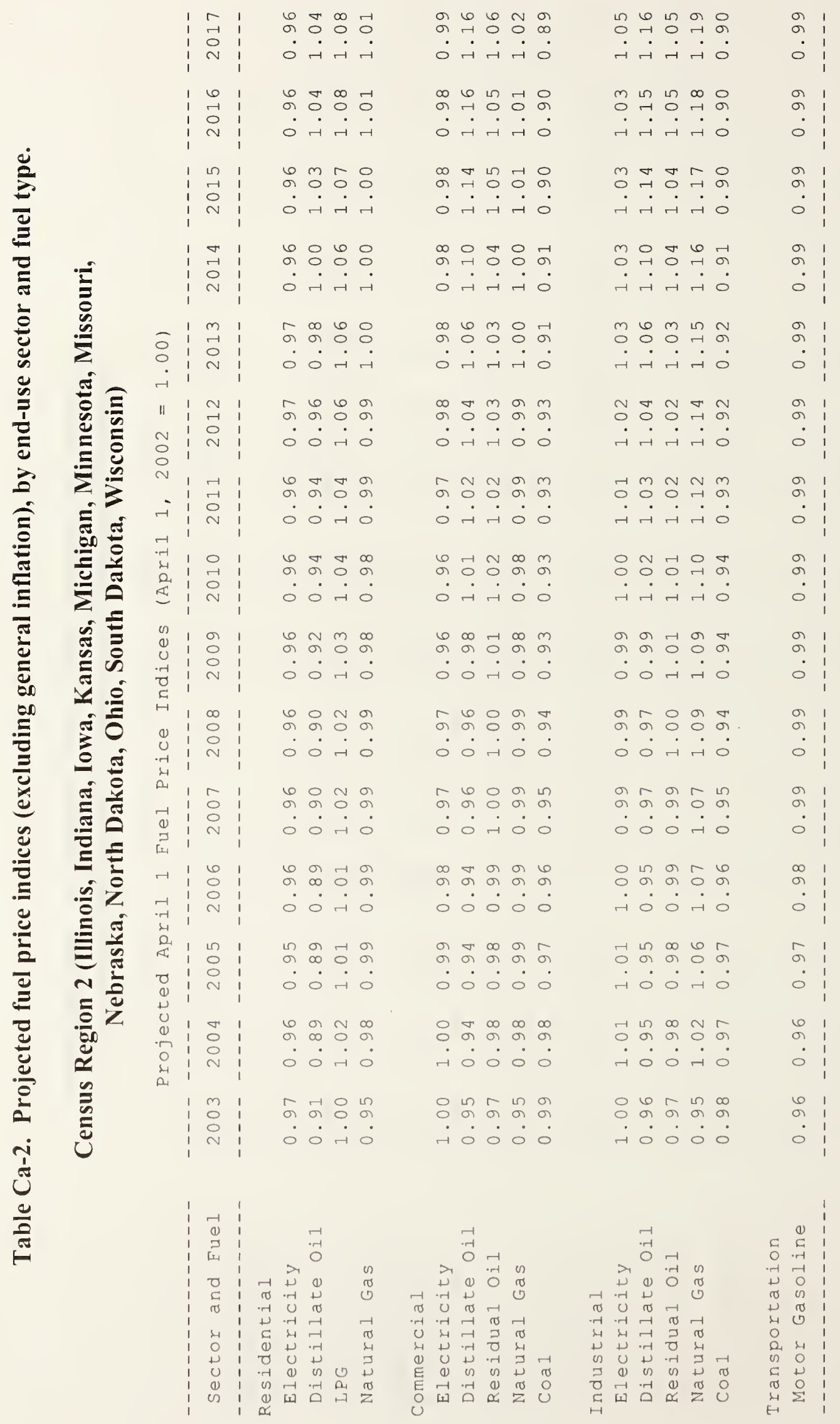




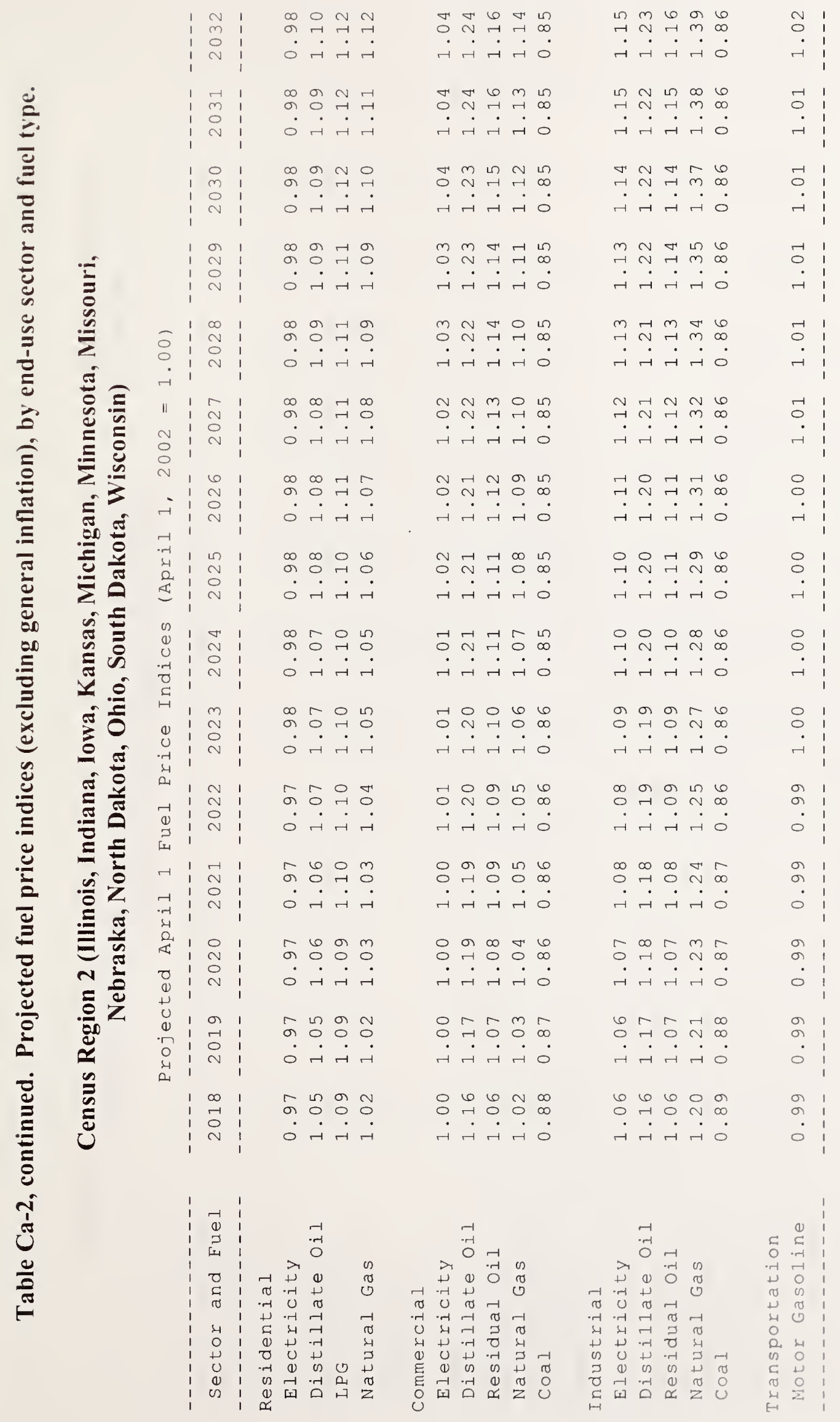




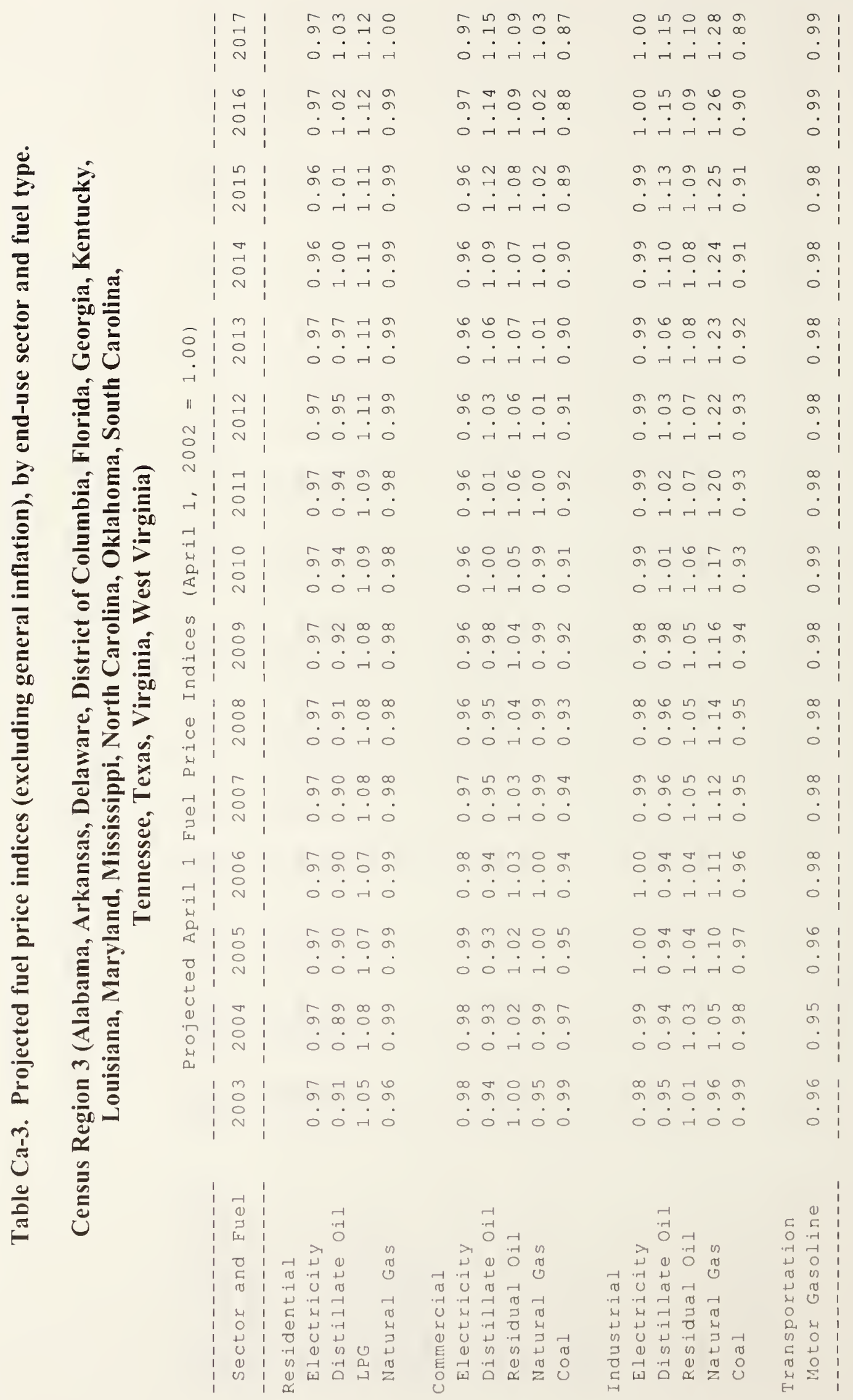




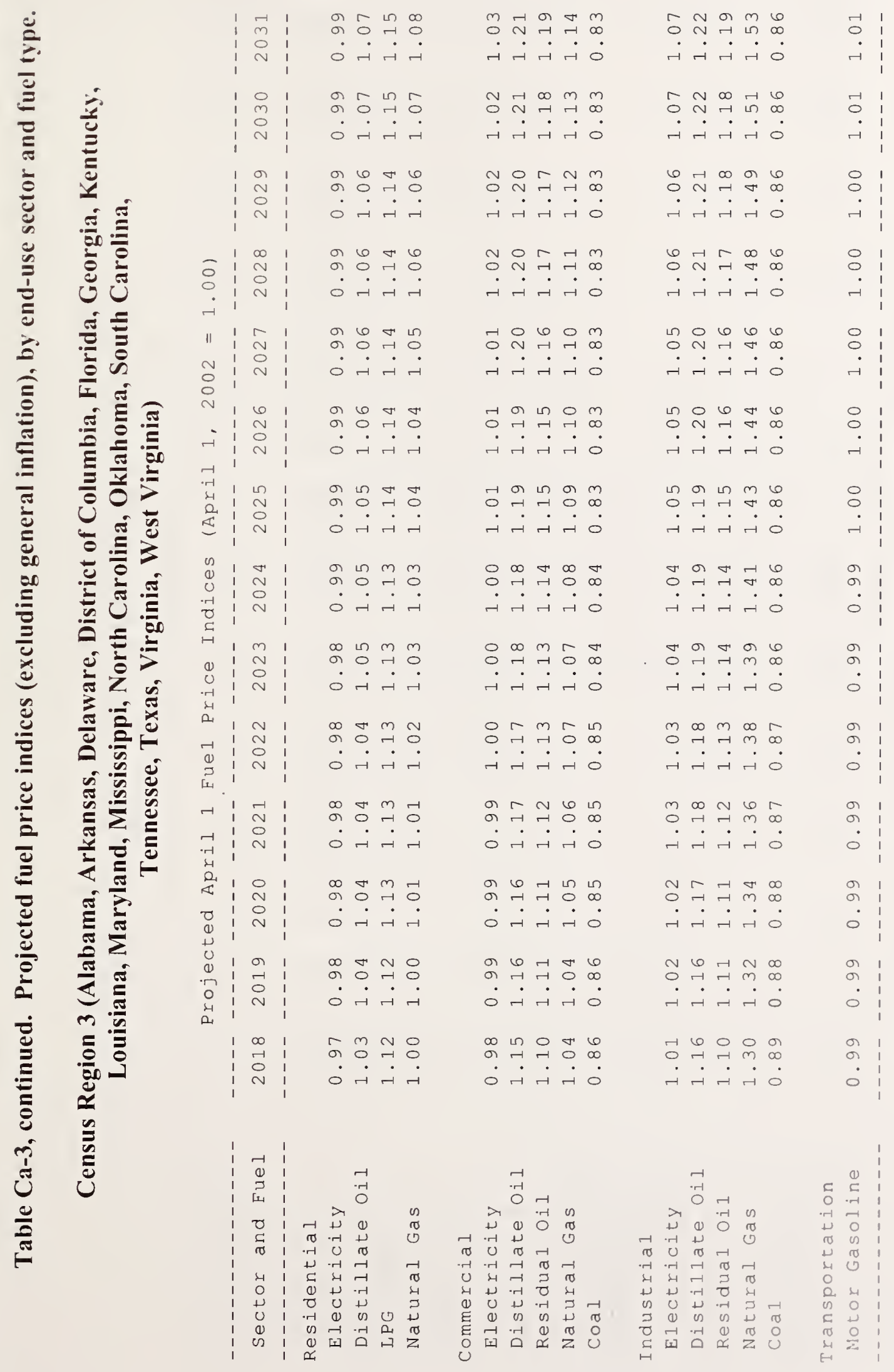




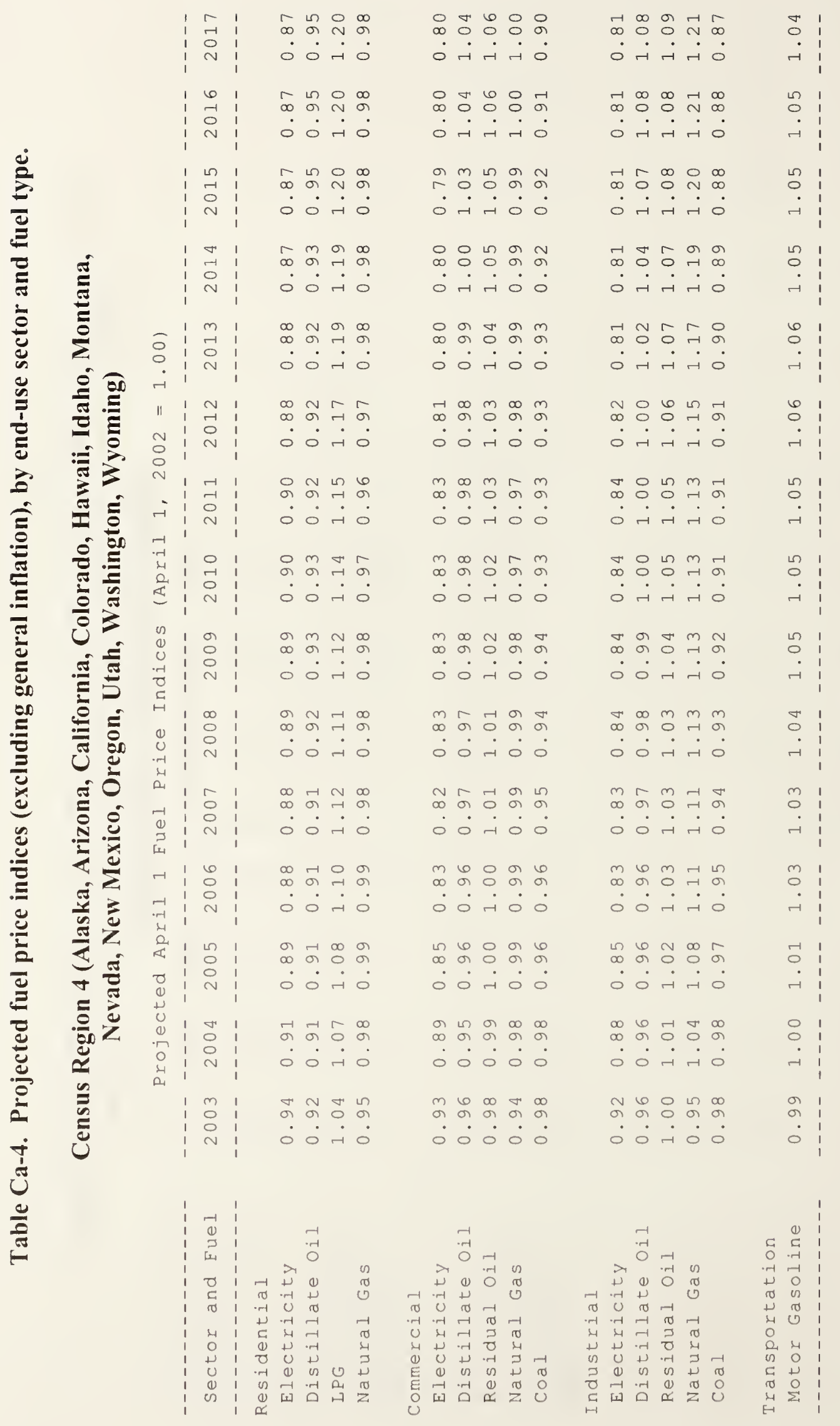




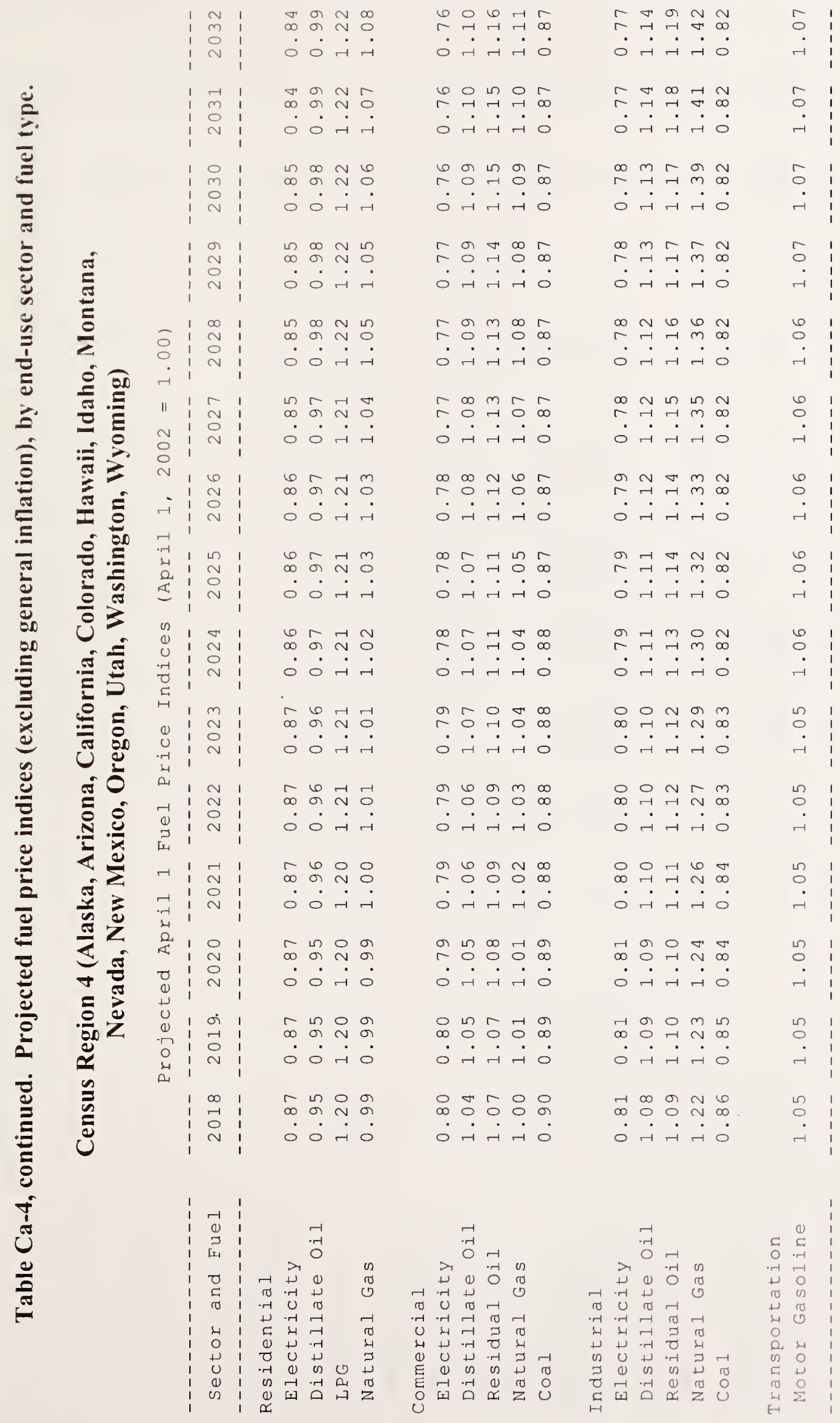




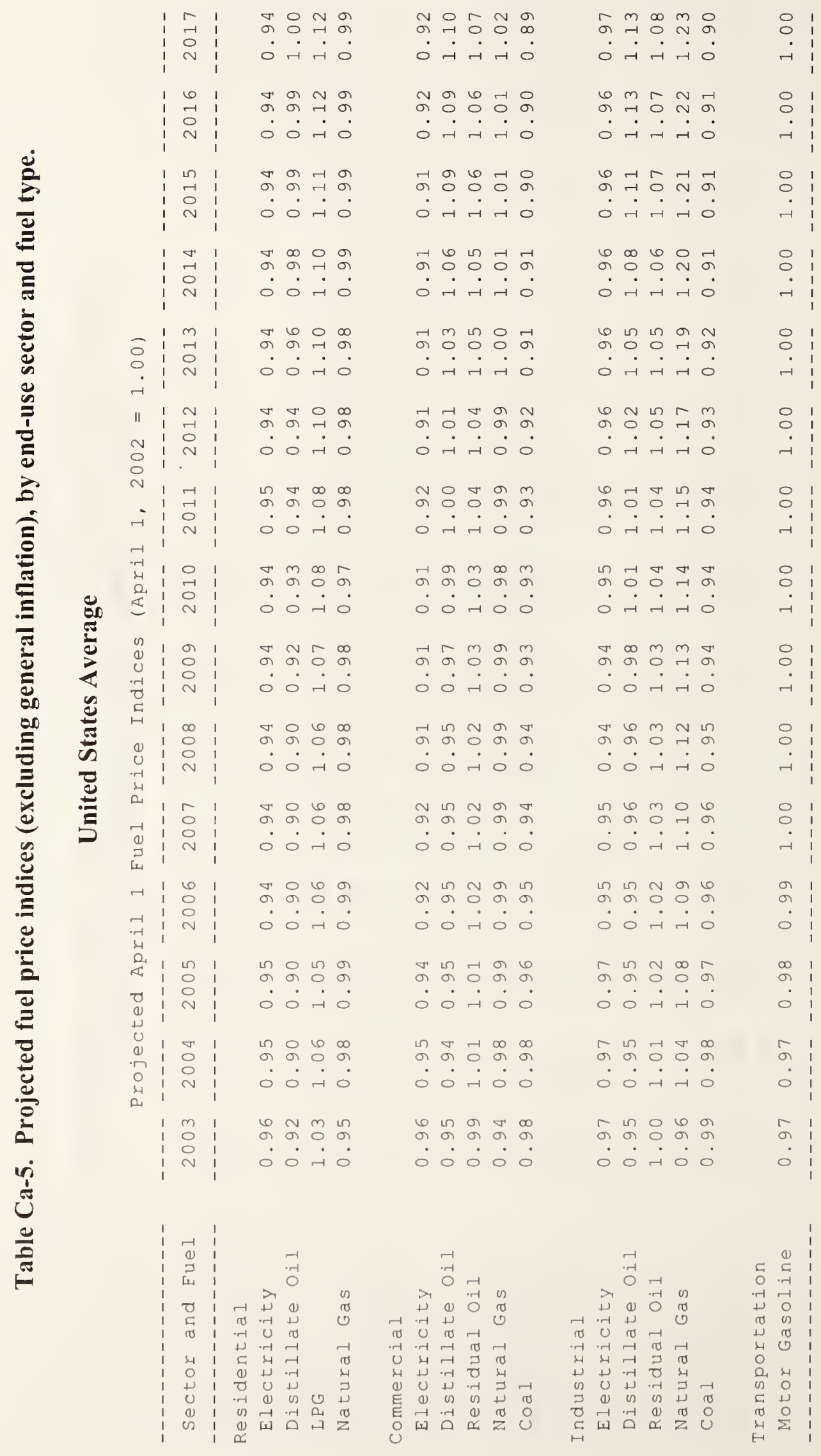




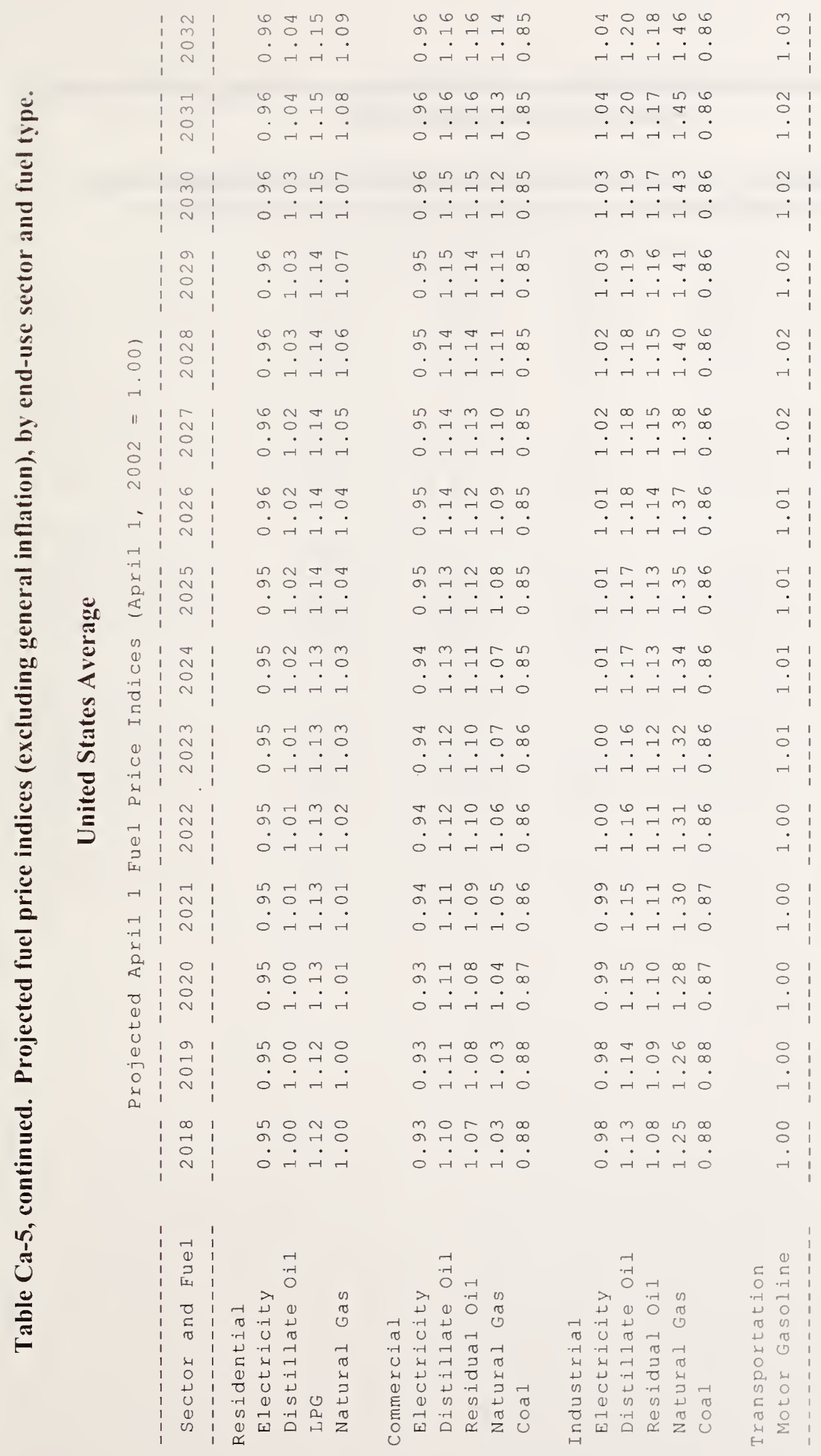


Table Cb-1. Projected average fuel price escalation rates, excluding general inflation, by end-use sector and fuel type.

Census Region 1 (Connecticut, Maine, Massachusetts, New Hampshire, New Jersey, New York, Pennsylvania, Rhode Island, Vermont)

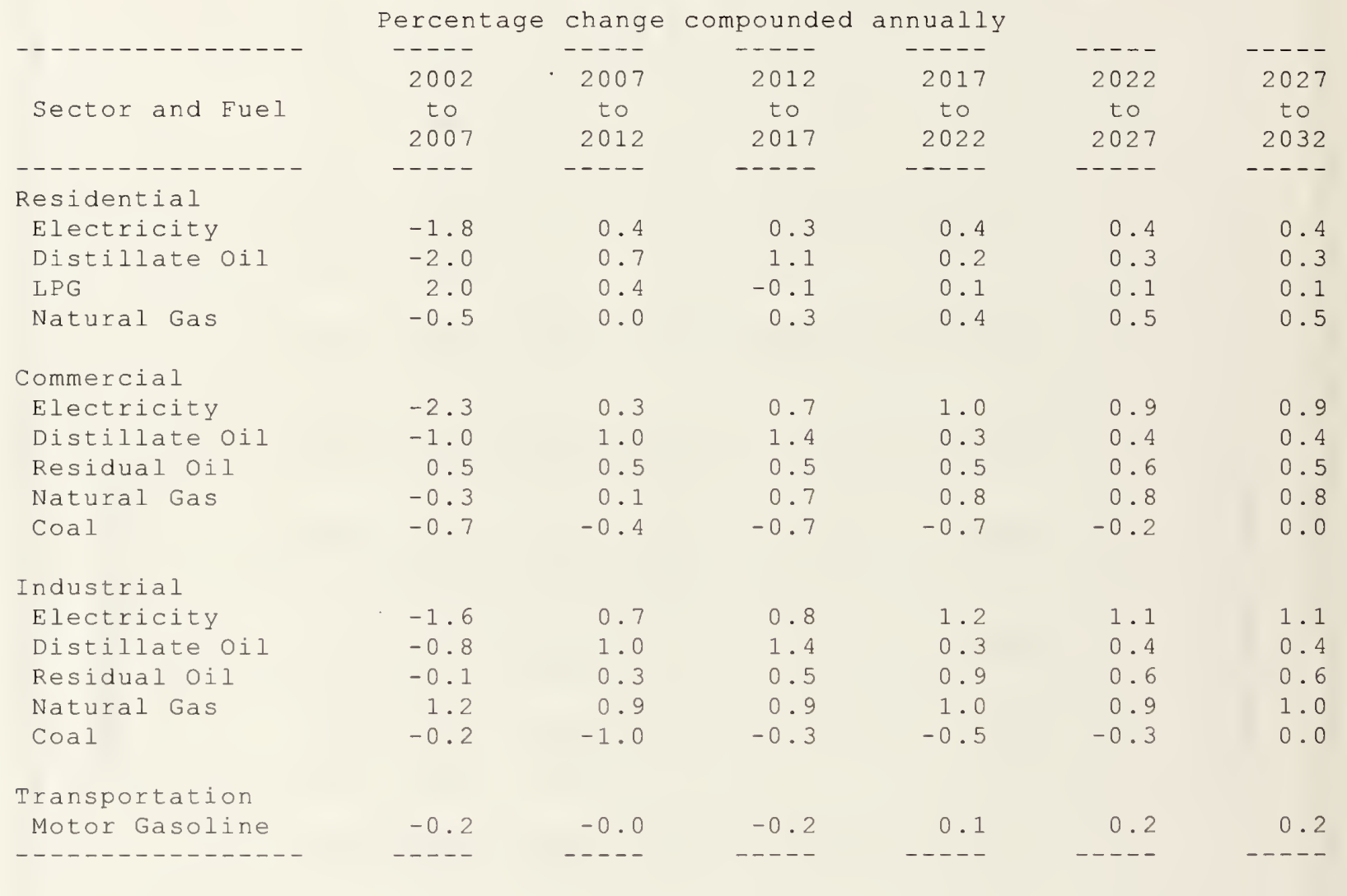


Table Cb-2. Projected average fuel price escalation rates, excluding general inflation, by end-use sector and fuel type.

Census Region 2 (Illinois, Indiana, Iowa, Kansas, Michigan, Minnesota, Missouri, Nebraska, North Dakota, Ohio, South Dakota, Wisconsin)

\begin{tabular}{|c|c|c|c|c|c|c|}
\hline 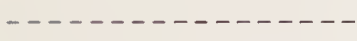 & ---- & $-\ldots$ & --- & $\ldots--$ & ---- & --- \\
\hline & 2002 & 2007 & 2012 & 2017 & 2022 & 2027 \\
\hline Sector and Fuel & to & to & to & to & to & to \\
\hline & 2007 & 2012 & 2017 & 2022 & 2027 & 2032 \\
\hline 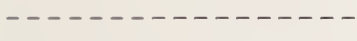 & ---- & ---- & ---- & ---- & ----- & --- \\
\hline Residential & & & & & & \\
\hline Electricity & -0.8 & 0.1 & -0.0 & 0.2 & 0.1 & 0.1 \\
\hline Distillate Oil & -2.1 & 1.2 & 1.8 & 0.4 & 0.3 & 0.3 \\
\hline LPG & 0.4 & 0.8 & 0.4 & 0.3 & 0.2 & 0.2 \\
\hline Natural Gas & -0.3 & 0.2 & 0.4 & 0.6 & 0.7 & 0.7 \\
\hline Commercial & & & & & & \\
\hline Electricity & -0.7 & 0.3 & 0.2 & 0.4 & 0.4 & 0.4 \\
\hline Distillate Oil & -0.9 & 1.6 & 2.4 & 0.6 & 0.4 & 0.4 \\
\hline Residual Oil & -0.1 & 0.6 & 0.6 & 0.6 & 0.7 & 0.6 \\
\hline Natural Gas & -0.3 & 0.2 & 0.5 & 0.7 & 0.8 & 0.8 \\
\hline Coal & -1.0 & -0.5 & -0.8 & -0.7 & -0.3 & 0.0 \\
\hline Industrial & & & & & & \\
\hline Electricity & -0.3 & 0.6 & 0.5 & 0.7 & 0.7 & 0.6 \\
\hline Distillate Oil & -0.7 & 1.5 & 2.2 & 0.5 & 0.3 & 0.3 \\
\hline Residual Oil & -0.1 & 0.6 & 0.6 & 0.6 & 0.6 & 0.6 \\
\hline Natural Gas & 1.4 & 1.2 & 0.9 & 1.1 & 1.0 & 1.1 \\
\hline Coal & -1.0 & -0.7 & -0.5 & -0.7 & -0.2 & 0.0 \\
\hline Transportation & & & & & & \\
\hline Motor Gasoline & -0.3 & 0.1 & 0.0 & 0.1 & 0.2 & 0.2 \\
\hline - - - - - - - - - & & 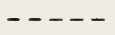 & - & & & \\
\hline
\end{tabular}


Table $\mathrm{Cb}-3$. Projected average fuel price escalation rates, excluding general inflation, by end-use sector and fuel type.

Census Region 3 (Alabama, Arkansas, Delaware, District of Columbia, Florida, Georgia, Kentucky, Louisiana, Maryland, Mississippi, North Carolina, Oklahoma, South Carolina, Tennessee, Texas, Virginia, West Virginia)

\begin{tabular}{|c|c|c|c|c|c|c|}
\hline \multirow{2}{*}{$-------n---1---$} & Percentage & change & compounded & annually & & - - - - \\
\hline & 2002 & 2007 & 2012 & 2017 & 2022 & 2027 \\
\hline \multirow{2}{*}{ Sector and Fuel } & to & to & to & to & to & to \\
\hline & 2007 & 2012 & 2017 & 2022 & 2027 & 2032 \\
\hline 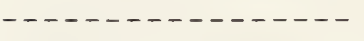 & ---- & ---- & ---- & ---- & ---- & $\ldots-$ \\
\hline \multicolumn{7}{|l|}{ Residential } \\
\hline Electricity & -0.6 & -0.0 & -0.0 & 0.3 & 0.1 & 0.1 \\
\hline Distillate Oil & -2.0 & 1.1 & 1.5 & 0.3 & 0.3 & 0.3 \\
\hline LPG & 1.5 & 0.5 & 0.3 & 0.2 & 0.2 & 0.2 \\
\hline Natural Gas & -0.3 & 0.1 & 0.2 & 0.5 & 0.6 & 0.6 \\
\hline \multicolumn{7}{|l|}{ Commercial } \\
\hline Electricity & -0.7 & -0.1 & 0.2 & 0.5 & 0.3 & 0.3 \\
\hline Distillate Oil & -1.0 & 1.6 & 2.3 & 0.5 & 0.4 & 0.4 \\
\hline Residual Oil & 0.6 & 0.6 & 0.6 & 0.6 & 0.6 & 0.6 \\
\hline Natural Gas & -0.2 & 0.3 & 0.4 & 0.8 & 0.7 & 0.7 \\
\hline Coal & $-1 \cdot 3$ & -0.6 & -0.9 & -0.6 & -0.3 & 0.0 \\
\hline \multicolumn{7}{|l|}{ Industrial } \\
\hline Electricity & -0.3 & 0.1 & 0.3 & 0.6 & 0.4 & 0.4 \\
\hline Distillate Oil & -0.9 & 1.5 & 2.3 & 0.5 & 0.4 & 0.4 \\
\hline Residual Oil & 0.9 & 0.5 & 0.5 & 0.6 & 0.6 & 0.6 \\
\hline Natural Gas & 2.2 & 1.8 & 1.0 & 1.5 & 1.1 & 1.2 \\
\hline Coal & -0.9 & -0.6 & -0.7 & -0.6 & -0.3 & 0.0 \\
\hline \multicolumn{7}{|l|}{ Transportation } \\
\hline Motor Gasoline & -0.3 & 0.0 & 0.0 & 0.1 & 0.2 & 0.2 \\
\hline$----\ldots---------$ & ---- & ---- & $-\ldots--$ & ---- & ----- & 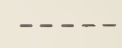 \\
\hline
\end{tabular}


Talble $\mathrm{Cb}-4$. Projected average fuel price escalation rates, excluding general inflation, by end-use sector and fuel type.

Census Region 4 (Alaska, Arizona, California, Colorado, Hawaii, Idaho, Montana, Nevada, New Mexico, Oregon, Utah, Washington, Wyoming)

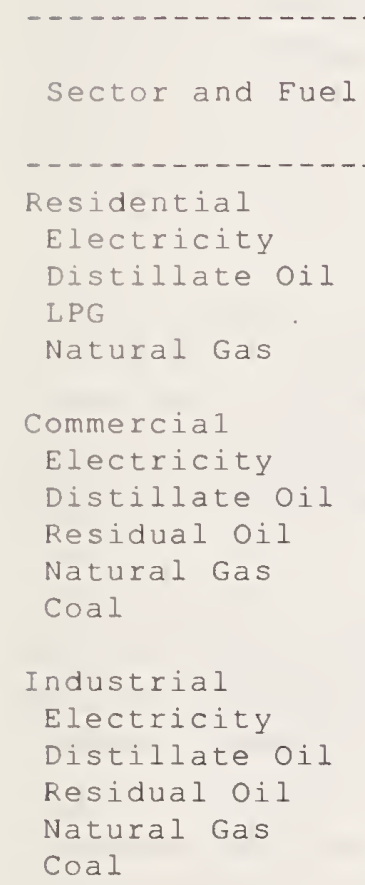

Transportation Motor Gasoline

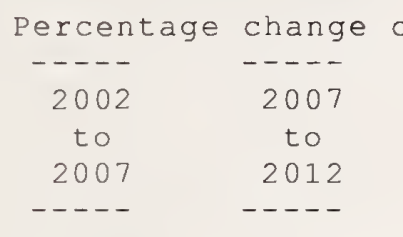

$-2.6$

$-1.8$

2.2

$-0.3$

$-3.8$

$-0.7$

0.2

$-0.2$

$-1.0$

$-3.6$

$-0.6$

0.6

2.2

$-1.2$

0.6 compounded

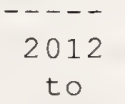

2017

- - - -

$-0.2$

0.7

0.5

0.3

$-0.2$

1.2

0.5

0.5

$-0.5$

\section{$-0.4$}

0.6

0.5

0.6

$-0.7$

0.5

\section{$-0.2$}

1. 5

0.5

1. 1

$-0.9$

$-0.3$ annualy

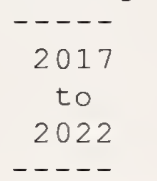

\section{$-0.1$}

0.3

0.0

0.5

$-0.2$

0.5

0.5

0.6

$-0.5$

\section{$-0.2$}

0.4

0.6

0.9

$-0.9$

0.1

2022
to
2027
-

$-0.3$

0.3

0.1

0.6

$-0.3$

0.3

0.1

0.7

$-0.4$

$-0.4$

0.4

0.6

0.7

$-0.3$

0.4

0.6

0.8

0.0

-0.4
0.4

$-0.4$

0.6

1. 1

$-0.2$

0.2

0.2 
Table $\mathrm{Cb}-5$. Projected average fuel price escalation rates, excluding general inflation, by end-use sector and fuel type.

\begin{tabular}{|c|c|c|c|c|c|c|}
\hline \multirow{3}{*}{-----------------} & Percentage & change & compounded & annually & & \\
\hline & ---- & ----- & ---- & ---- & ----- & ---- \\
\hline & 2002 & 2007 & 2012 & 2017 & 2022 & 2027 \\
\hline \multirow[t]{2}{*}{ Sector and Fuel } & to & to & to & to & to & to \\
\hline & 2007 & 2012 & 2017 & 2022 & 2027 & 2032 \\
\hline$-\cdots-\cdots-\cdots-\cdots--$ & ----- & ----- & ----- & ----- & ----- & ----- \\
\hline \multicolumn{7}{|l|}{ Residential } \\
\hline Electricity & -1.2 & 0.0 & -0.0 & 0.2 & 0.1 & 0.1 \\
\hline Distillate Oil & -2.0 & 0.8 & 1.2 & 0.3 & 0.3 & 0.3 \\
\hline $\mathrm{LPG}$ & 1.2 & 0.7 & 0.3 & 0.2 & 0.2 & 0.2 \\
\hline Natural Gas & -0.4 & 0.0 & 0.3 & 0.5 & 0.6 & 0.7 \\
\hline \multicolumn{7}{|l|}{ Commercial } \\
\hline Electricity & -1.8 & -0.0 & 0.2 & 0.4 & 0.2 & 0.2 \\
\hline Distillate Oil & -1.0 & 1.2 & 1.7 & 0.4 & 0.4 & 0.4 \\
\hline Residual Oil & 0.4 & 0.5 & 0.5 & 0.6 & 0.6 & 0.6 \\
\hline Natural Gas & -0.3 & 0.1 & 0.5 & 0.7 & 0.8 & 0.8 \\
\hline Coal & -1.1 & -0.5 & -0.7 & -0.6 & -0.3 & 0.0 \\
\hline \multicolumn{7}{|l|}{ Industrial } \\
\hline Electricity & -1.1 & 0.2 & 0.3 & 0.6 & 0.4 & 0.4 \\
\hline Distillate Oil & -0.8 & 1.3 & 2.0 & 0.5 & 0.4 & 0.3 \\
\hline Residual Oil & 0.5 & 0.4 & 0.6 & 0.6 & 0.6 & 0.6 \\
\hline Natural Gas & 1.9 & 1.3 & 1.0 & 1.2 & 1.1 & 1.1 \\
\hline Coal 1 & -0.9 & -0.6 & -0.6 & -0.8 & -0.2 & 0.0 \\
\hline \multicolumn{7}{|l|}{ Transportation } \\
\hline Motor Gasoline & -0.1 & 0.2 & -0.1 & 0.1 & 0.2 & 0.2 \\
\hline$-------------\cdots$ & ----- & ----- & ----- & ----- & ---- & ----- \\
\hline
\end{tabular}

\begin{tabular}{|c|c|c|c|c|c|c|}
\hline \multirow{3}{*}{-----------------} & Percentage & change & compounded & annually & & \\
\hline & ---- & ----- & ---- & ---- & ----- & ---- \\
\hline & 2002 & 2007 & 2012 & 2017 & 2022 & 2027 \\
\hline \multirow[t]{2}{*}{ Sector and Fuel } & to & to & to & to & to & to \\
\hline & 2007 & 2012 & 2017 & 2022 & 2027 & 2032 \\
\hline$-\cdots-\cdots-\cdots-\cdots--$ & ----- & ----- & ----- & ----- & ----- & ----- \\
\hline \multicolumn{7}{|l|}{ Residential } \\
\hline Electricity & -1.2 & 0.0 & -0.0 & 0.2 & 0.1 & 0.1 \\
\hline Distillate Oil & -2.0 & 0.8 & 1.2 & 0.3 & 0.3 & 0.3 \\
\hline $\mathrm{LPG}$ & 1.2 & 0.7 & 0.3 & 0.2 & 0.2 & 0.2 \\
\hline Natural Gas & -0.4 & 0.0 & 0.3 & 0.5 & 0.6 & 0.7 \\
\hline \multicolumn{7}{|l|}{ Commercial } \\
\hline Electricity & -1.8 & -0.0 & 0.2 & 0.4 & 0.2 & 0.2 \\
\hline Distillate Oil & -1.0 & 1.2 & 1.7 & 0.4 & 0.4 & 0.4 \\
\hline Residual Oil & 0.4 & 0.5 & 0.5 & 0.6 & 0.6 & 0.6 \\
\hline Natural Gas & -0.3 & 0.1 & 0.5 & 0.7 & 0.8 & 0.8 \\
\hline Coal & -1.1 & -0.5 & -0.7 & -0.6 & -0.3 & 0.0 \\
\hline \multicolumn{7}{|l|}{ Industrial } \\
\hline Electricity & -1.1 & 0.2 & 0.3 & 0.6 & 0.4 & 0.4 \\
\hline Distillate Oil & -0.8 & 1.3 & 2.0 & 0.5 & 0.4 & 0.3 \\
\hline Residual Oil & 0.5 & 0.4 & 0.6 & 0.6 & 0.6 & 0.6 \\
\hline Natural Gas & 1.9 & 1.3 & 1.0 & 1.2 & 1.1 & 1.1 \\
\hline Coal 1 & -0.9 & -0.6 & -0.6 & -0.8 & -0.2 & 0.0 \\
\hline \multicolumn{7}{|l|}{ Transportation } \\
\hline Motor Gasoline & -0.1 & 0.2 & -0.1 & 0.1 & 0.2 & 0.2 \\
\hline$-------------\cdots$ & ----- & ----- & ----- & ----- & ---- & ----- \\
\hline
\end{tabular}

\section{United States Average}




\section{PART II: ENERGY PRICE INDICES FOR PRIVATE SECTOR LCC ANALYSIS}

This section presents tables of projected nominal (i.e., including inflation) fuel price indices for four fuels in the residential sector and five fuels in the commercial sector for each of the years from 2002 through 2032. These price indices are based on the DOE energy price projections, reported in part I-B of this document, used to calculate the FEMP and OMB UPV* factors for energy costs. The tables are provided as an update to similar tables originally published in Comprehensive Guide for Least-Cost Energy Decisions (NBS SP 709).

As a convenience for the user, the indices include the effect of four alternative, hypothetical rates of general price inflation: $2,3,4$, and $5 \%$. Selection of these rates is in no way intended to suggest what actual rates might be. Use of the indices produce price estimates which are in current dollars, inclusive of general price inflation. Current dollar prices are needed when discounting is performed with discount rates that include general price inflation (i.e., nominal or market discount rates).

The indices based on inflation rates of 2,3,4, and 5\% allow the analyst to perform evaluations based on the assumption of a positive rate of general price inflation that changes the purchasing power of the dollar. Performing evaluations in current dollars is sometimes preferred for private investment decisions, primarily because it facilitates the treatment of taxes.

The indices in Tables S-1 through S- 5 are derived from the indices reported in Tables Ca-1 through $\mathrm{Ca}-5$ by means of the following equation:

$$
I_{S}=I_{C} x(1+g)^{N},
$$

where $\quad \mathrm{I}_{\mathrm{S}}=$ index found in Tables $\mathrm{S}-1$ through $\mathrm{S}-5$;

$\mathrm{I}_{\mathrm{C}}=$ index found in Tables Ca-1 through $\mathrm{Ca}-5$;

$\mathrm{g}=$ annual rate of general price inflation in decimal form; and

$\mathrm{N}=$ number of years, in this case equal to the year of the index minus 2002.

\section{Example of How to Use the Indices:}

Suppose you wish to estimate the annual cost of natural gas for a house in Maryland in ycar 2005. given the annual cost in 2002 (April 1) prices, and you expect an annual inflation rate of $3 \%$ per ycar. From table S-3. find the column with residential natural gas indices at an inflation ratc of 3\%: then locate the index for the year 2005. This index is 1.09. Multiply the annual cost in 2002 prices to find the estimated annual cost in year-2005 prices.

If this annual cost in year-2005 prices is to be discounted to present value. you must use a nominal discount rate that includes the same assumption with regard to general price inflation ( $3 \%$ in this example). To obtain a present-value cost over the entire study period, the present-valuc calculation must be repeated for each year that there are natural gas costs, and the results summed. (UPV* 
factors are not given for private sector use because of the large number of tables required to cover potential discount rates that might be used by the analyst.) The BLCC computer program can perform LCC analyses using any inflation rate and discount rate, in constant or in current (market) dollars. The DISCOUNT program, included with BLCC, can compute UPV* factors based on DOE energy price escalation rates using any inflation rate and discount rate. (See page iv for more information on these programs.) Of course, the private sector analyst may use the UPV* factors reported in Part I, provided the analysis is performed in constant dollars and the desired discount rate corresponds to the DOE or OMB discount rates used in Part I.

For further explanation of the use of these indices, see NBS Special Publication 709, appendix B, Part I.

The data in the tables that follow are reported for the four Census regions and the U.S. average. Figure B-1 on page 13 presents a map showing the states corresponding to the four Census regions. The Census regions do not include American Samoa, Canal Zone, Guam, Puerto Rico, Trust Territory of the Pacific Islands, or the Virgin Islands. Analysts of federal projects in these areas should use data which are "reasonable under the circumstances," and may refer to the tables with U.S. average data for guidance. 


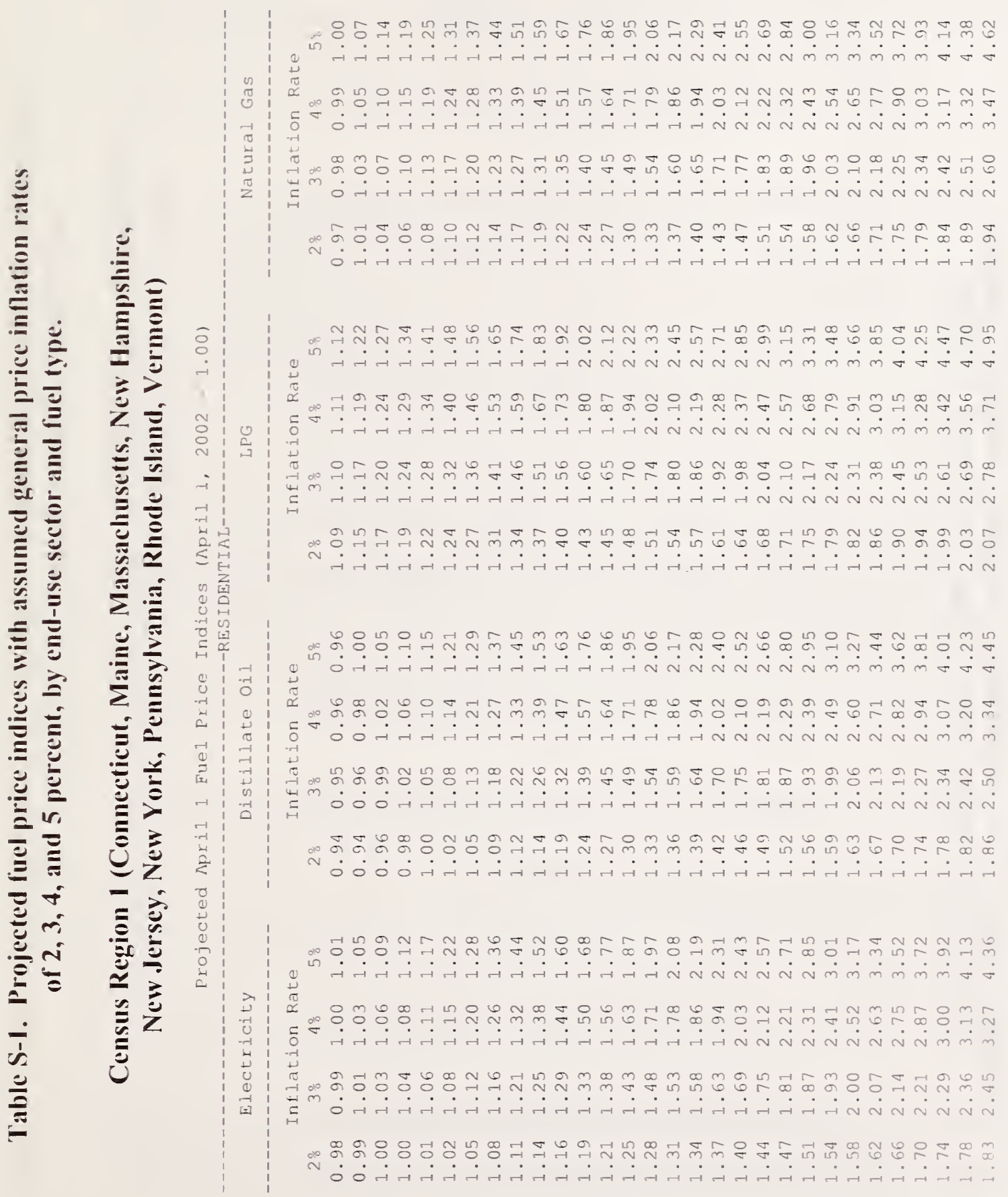

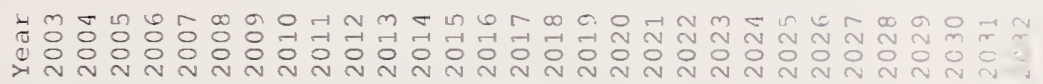




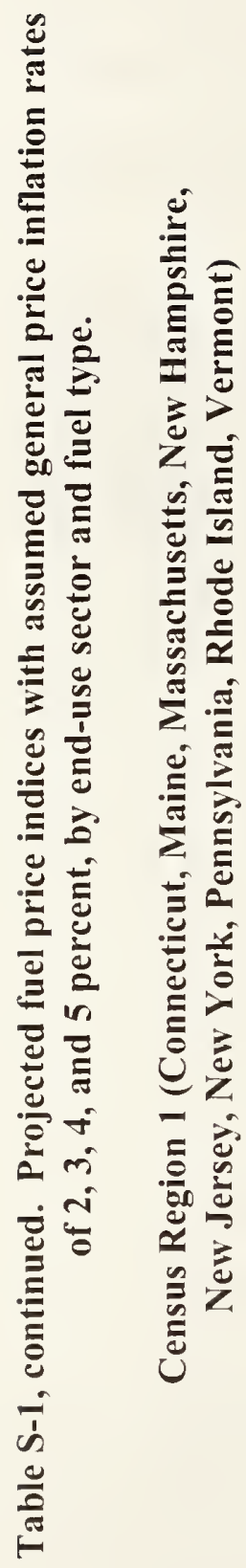

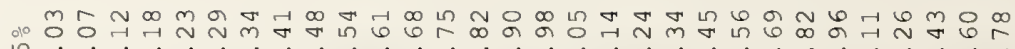

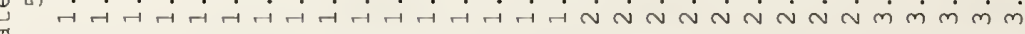

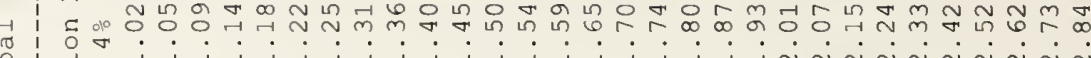
ס 岀

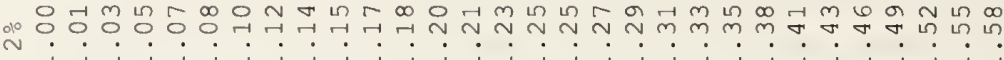

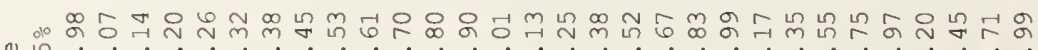
(3)

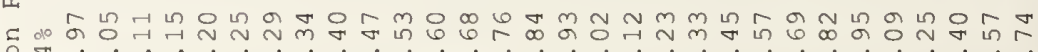

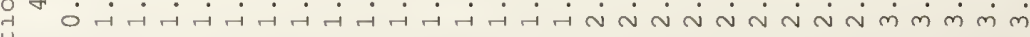
湈 0 .

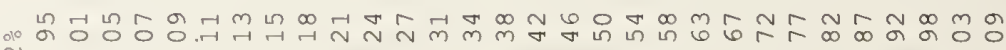

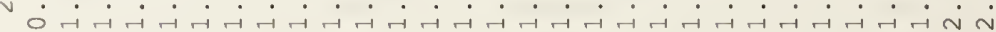

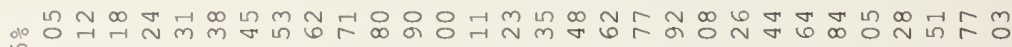
-1 œ

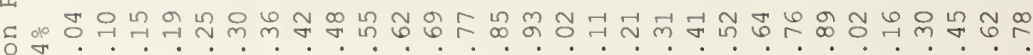
击

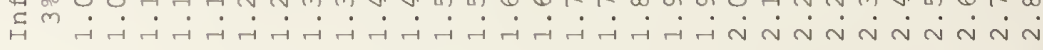

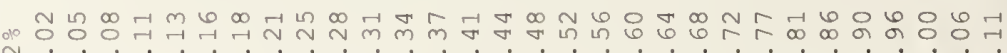
4म

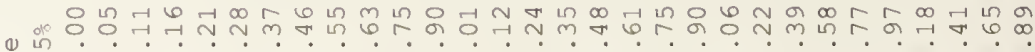
崖

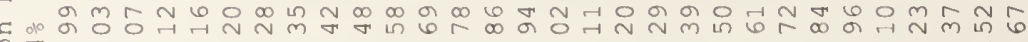

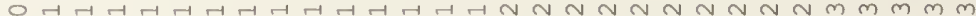

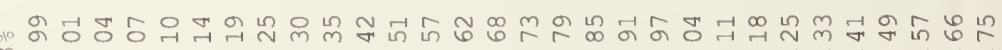
मfन

舟 0े वं

th सं

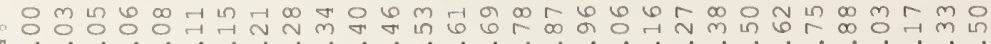

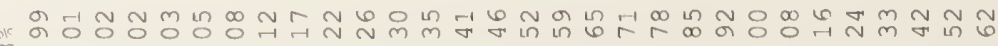

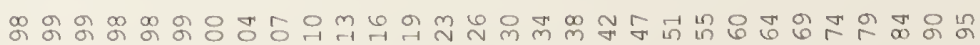

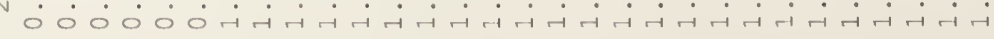




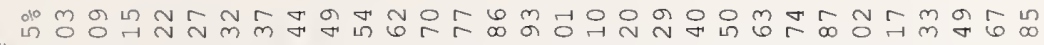
 药 4

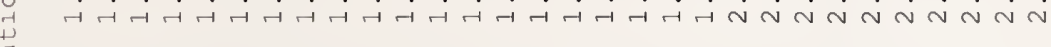

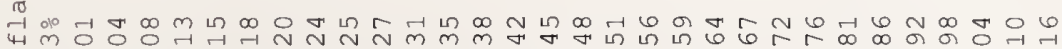

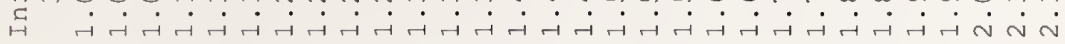

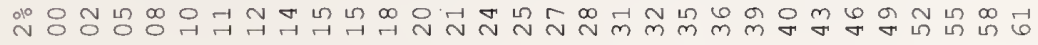

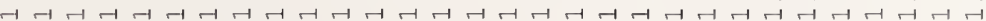

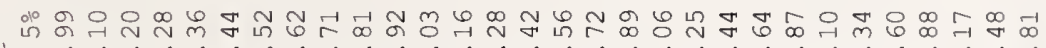
$\frac{1}{20}$ 마

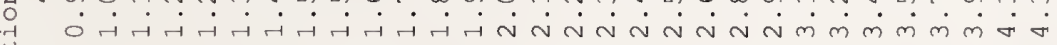

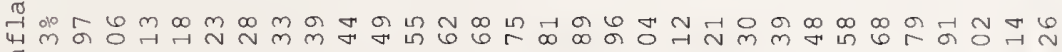
H 0 ન

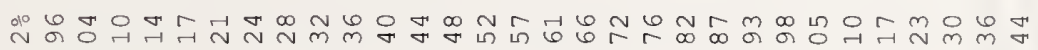

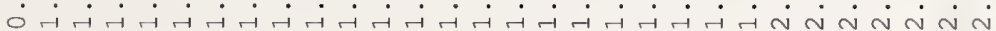

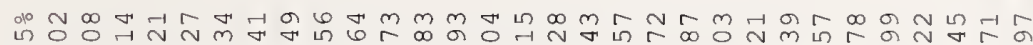
॥ $\widetilde{1}$

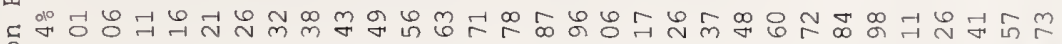

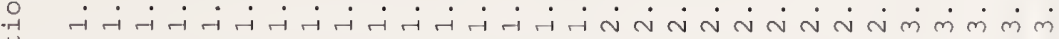
元 म

ํㅏㅇㅢ

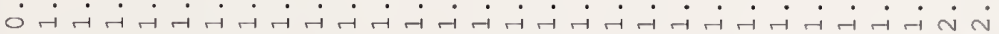

가유

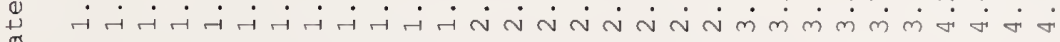
$\widetilde{\alpha}$

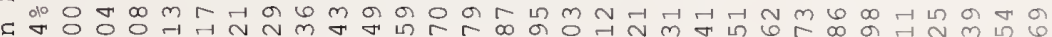

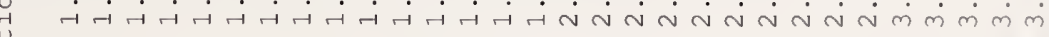
岀

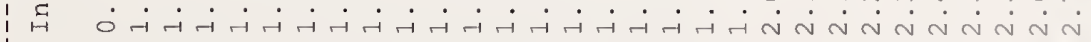

웅

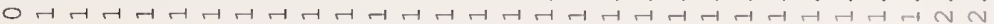

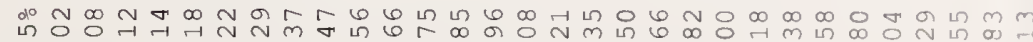
$\stackrel{0}{+}$

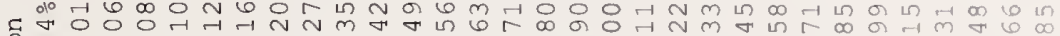
H Н

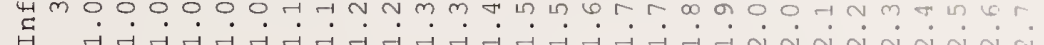

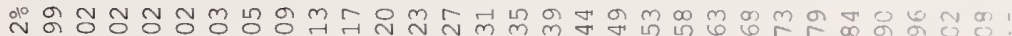

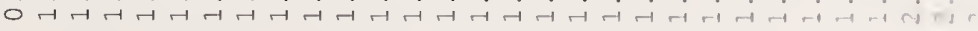

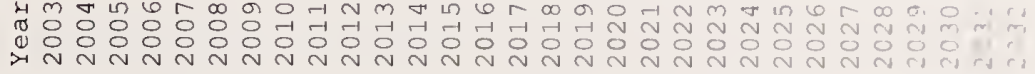




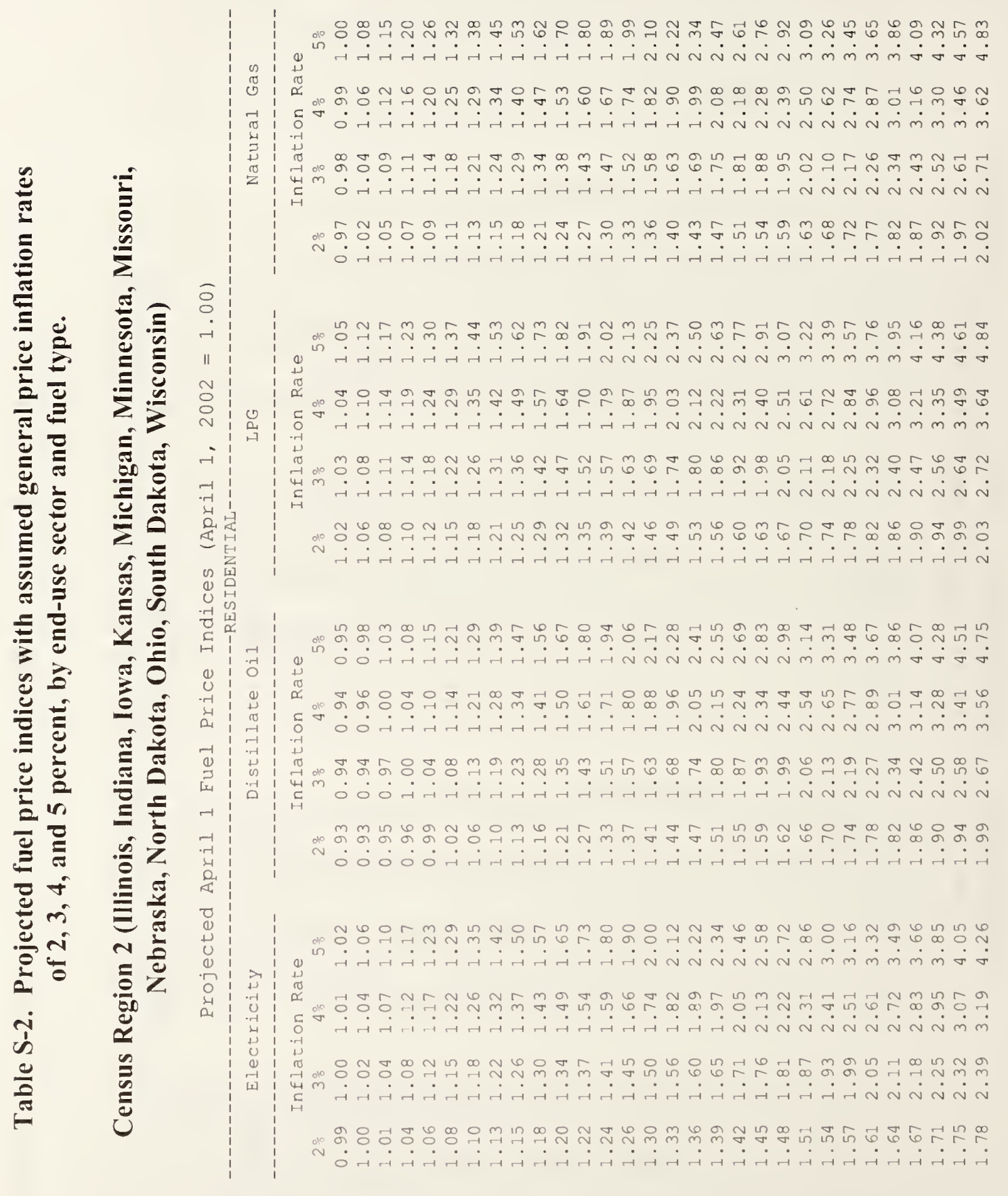

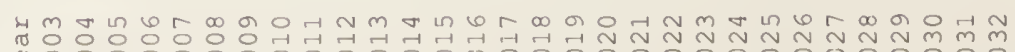

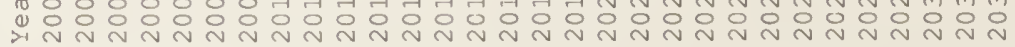


ॠ $\forall N N N$ N $N$ N

पुऽ t

๙

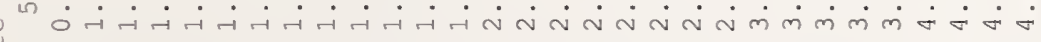

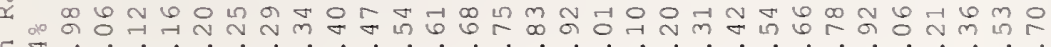
व ণ व न न ન ન

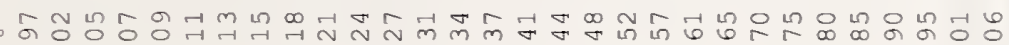

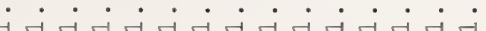

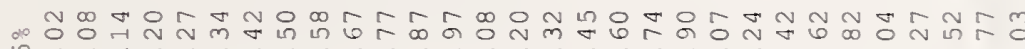

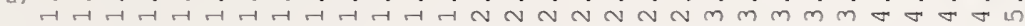
๔ वंन r द

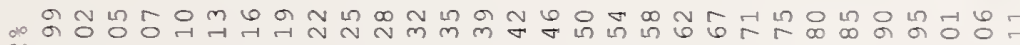

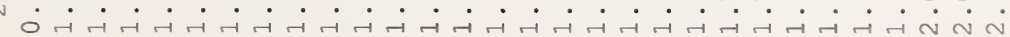

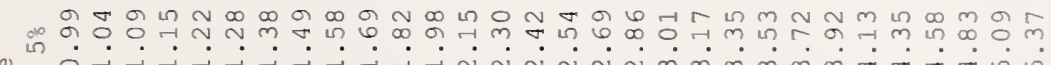
प्रनન न

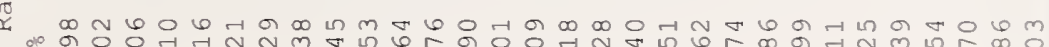
ई త్ర

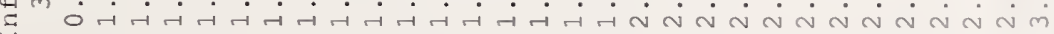

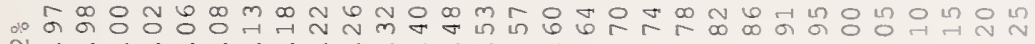

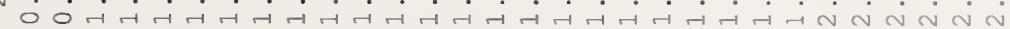

แก 유

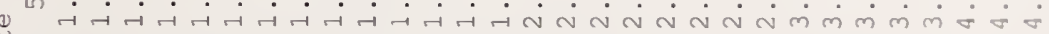
$x$ ए ,

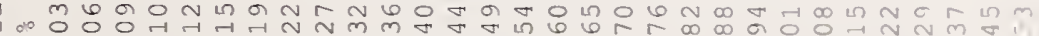
मौन न न

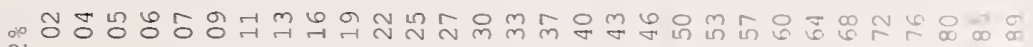

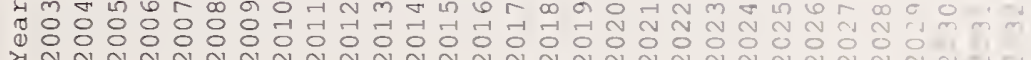




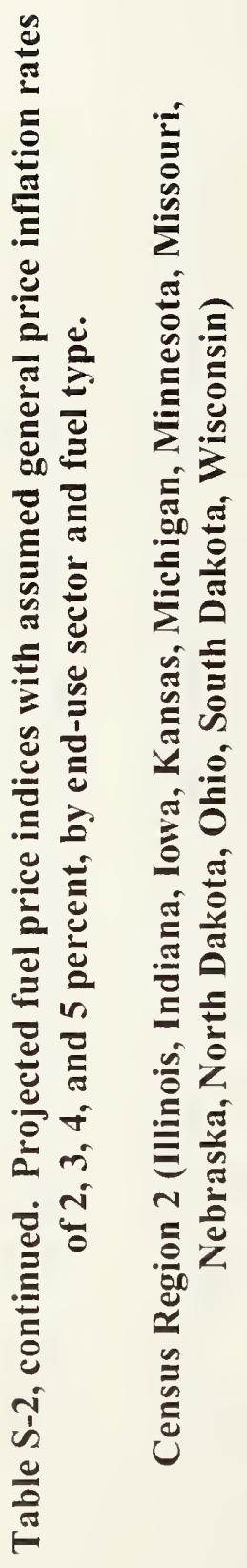

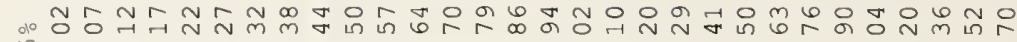

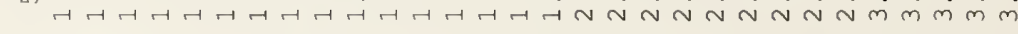

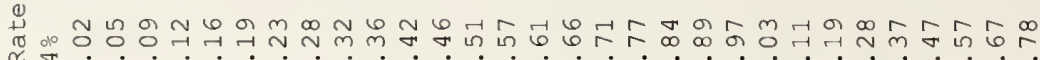

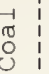
o

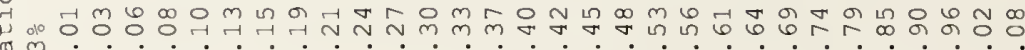

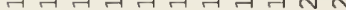

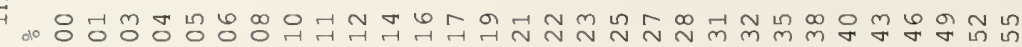

ข

m (1) శ్

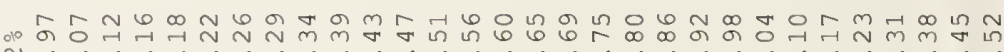

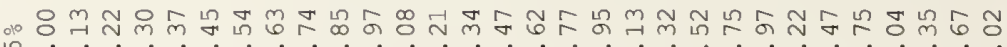

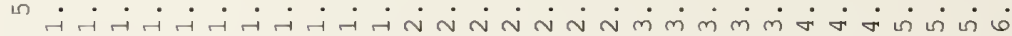

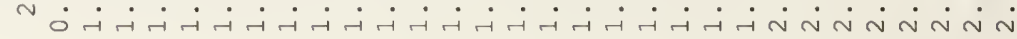

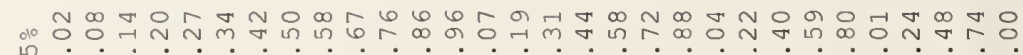
0.

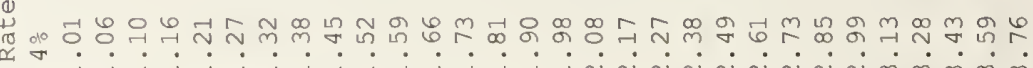

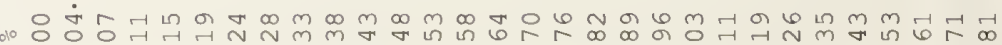
न

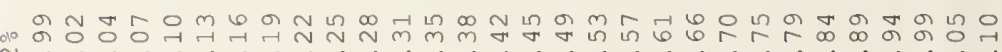
र०

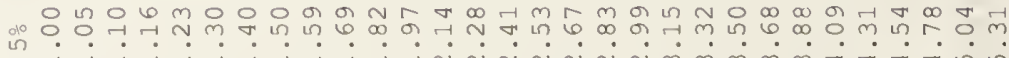
-

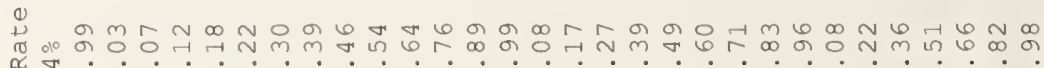
凹

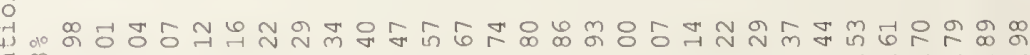

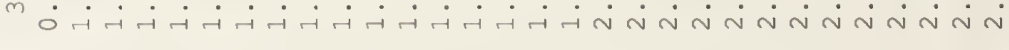
我 N 0.

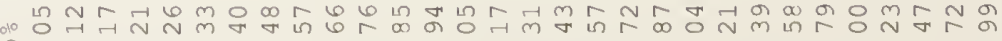

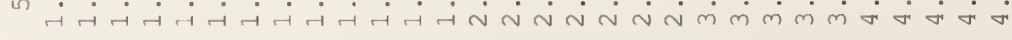

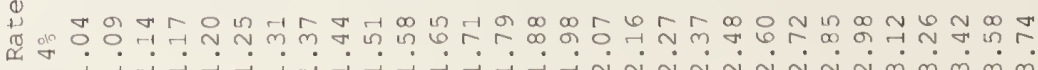

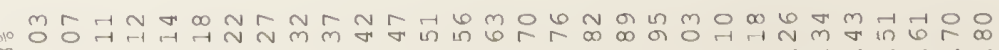

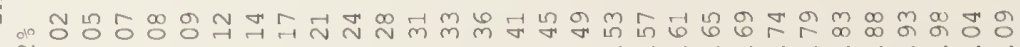
vंнत

Hm

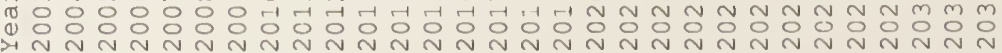




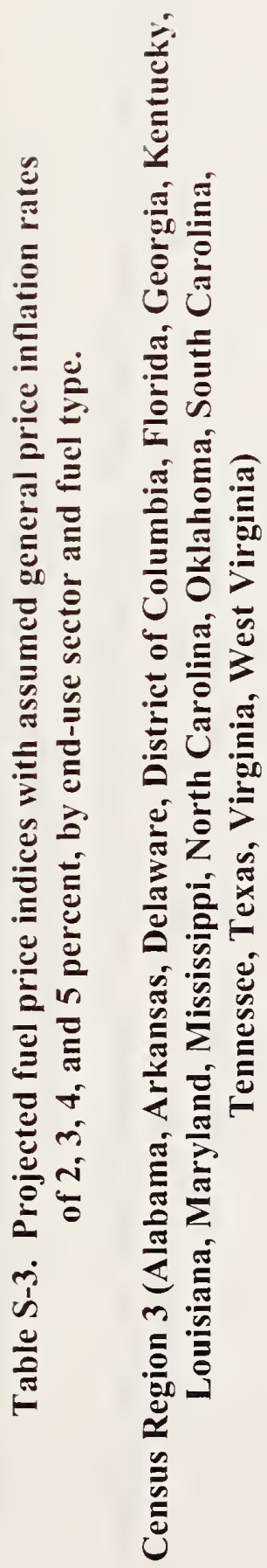

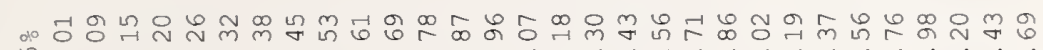

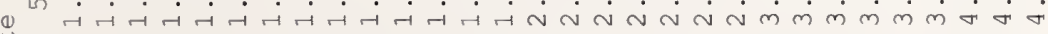

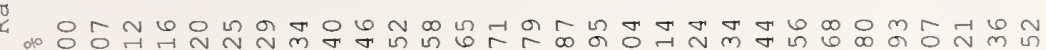

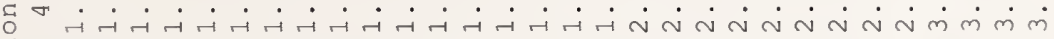

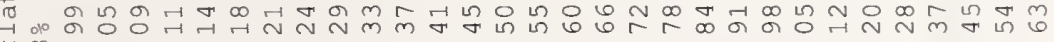

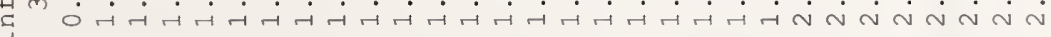

do

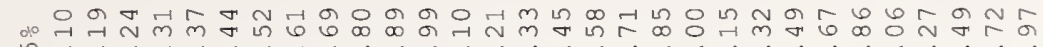

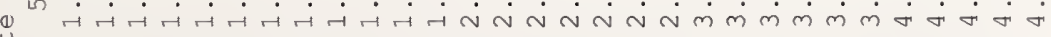

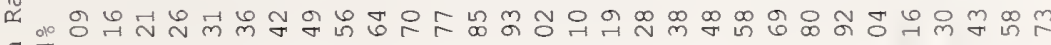
đํ

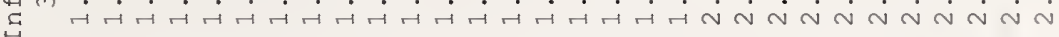

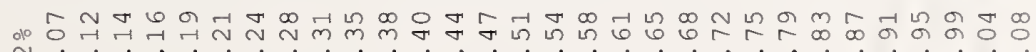

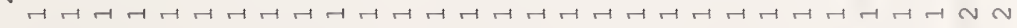

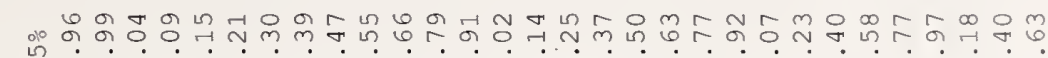

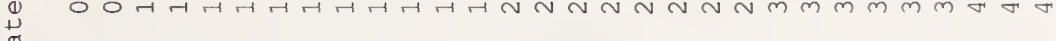
« 의 ठ०

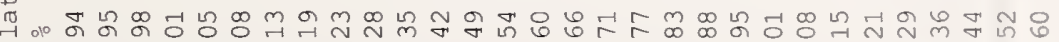

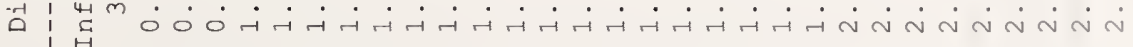

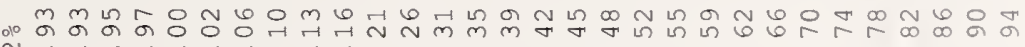
人 ठ

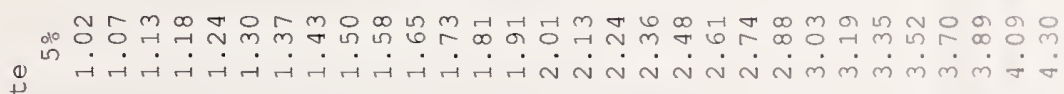
品

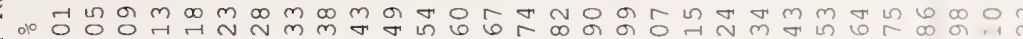

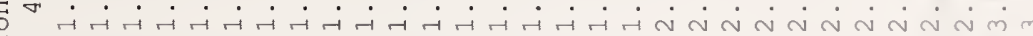

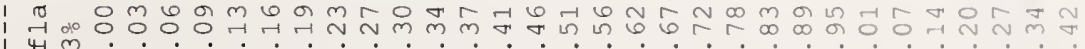

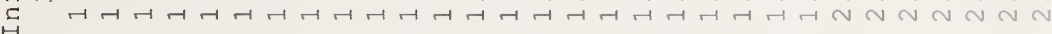

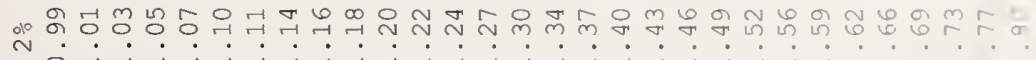

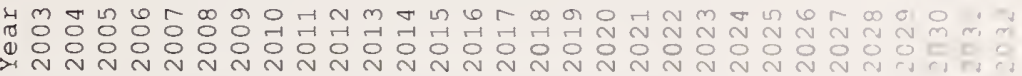




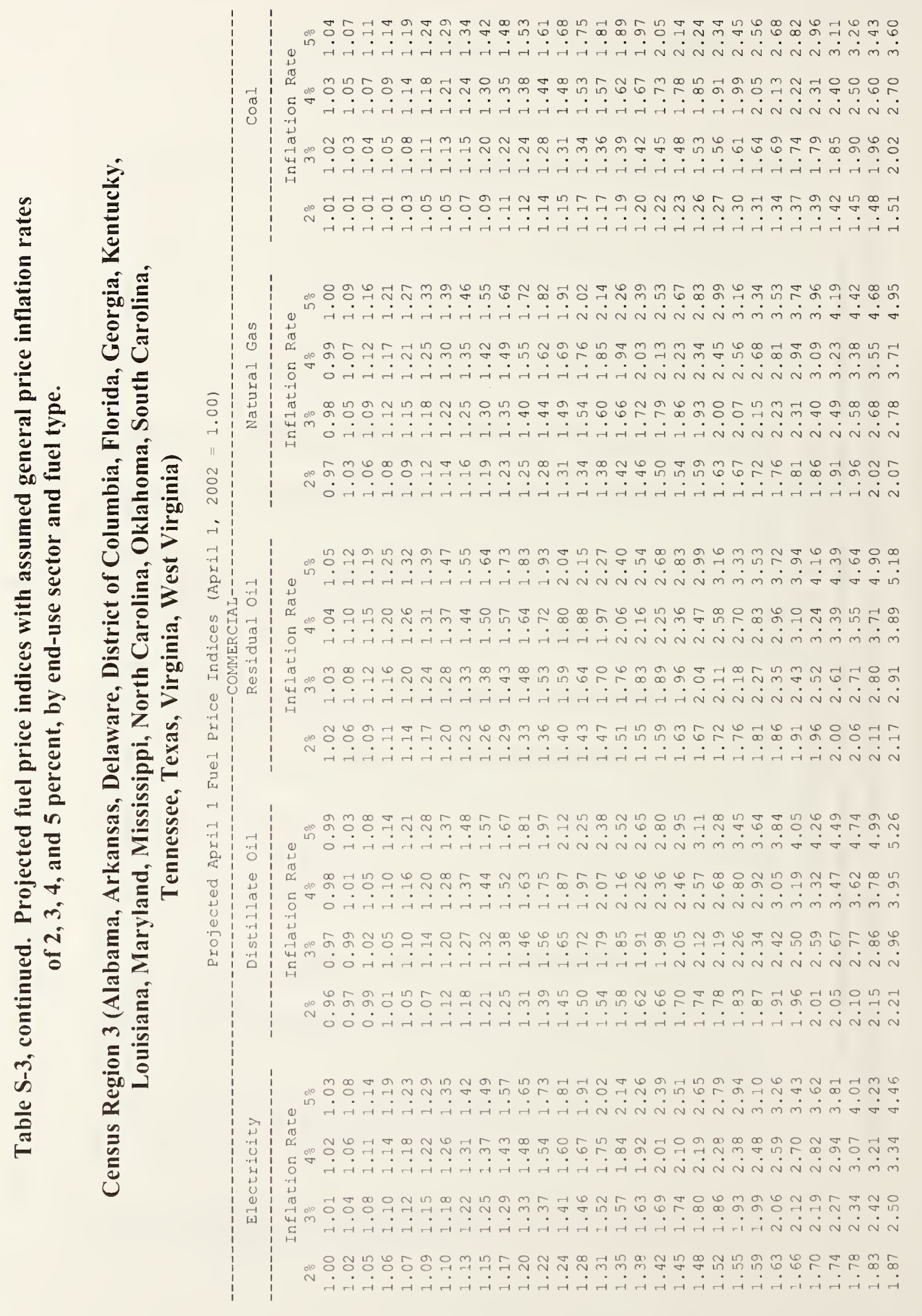

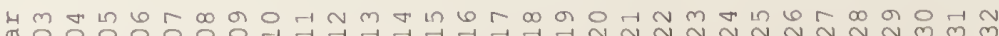

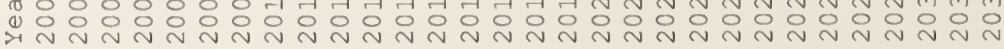




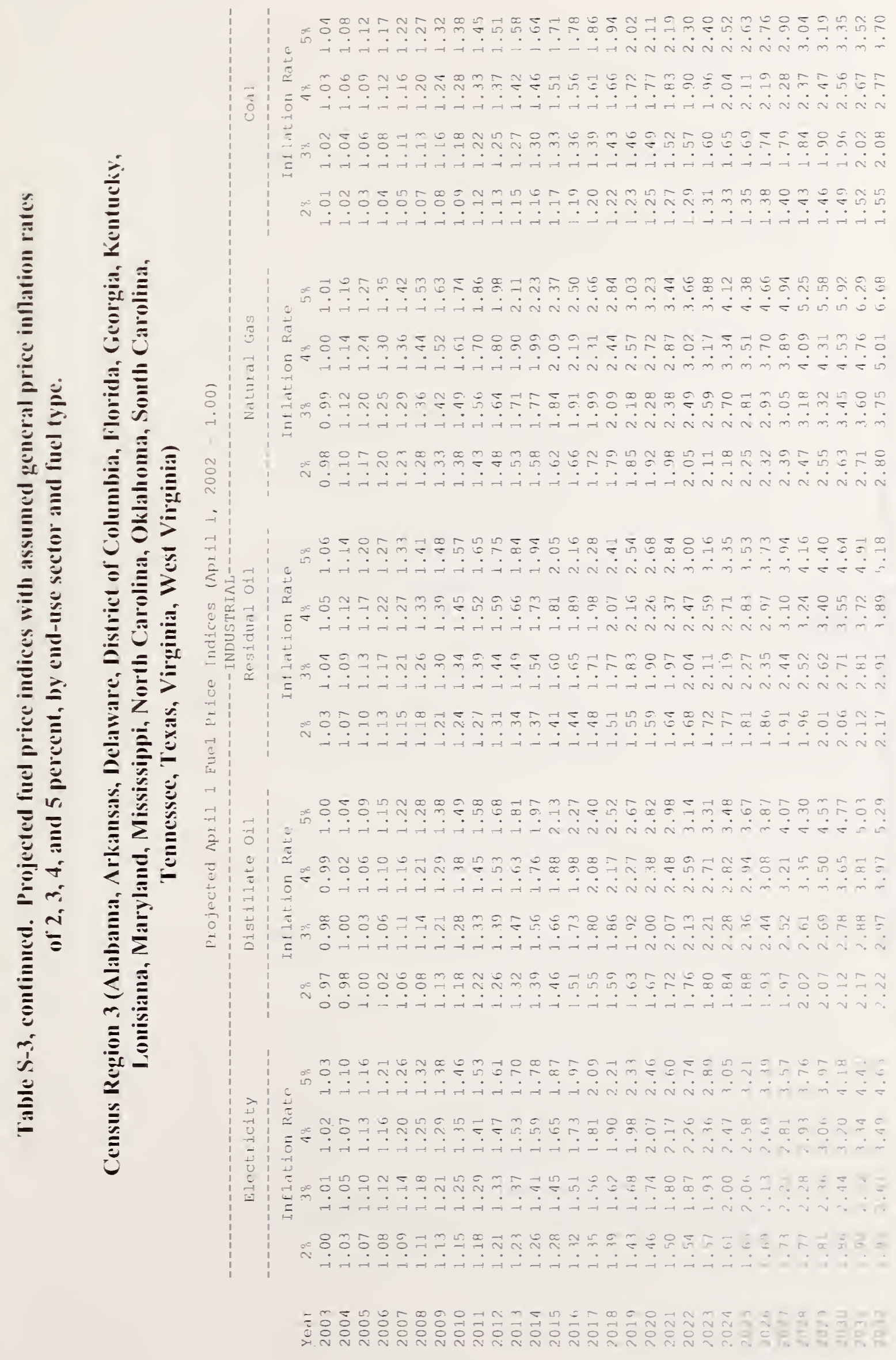




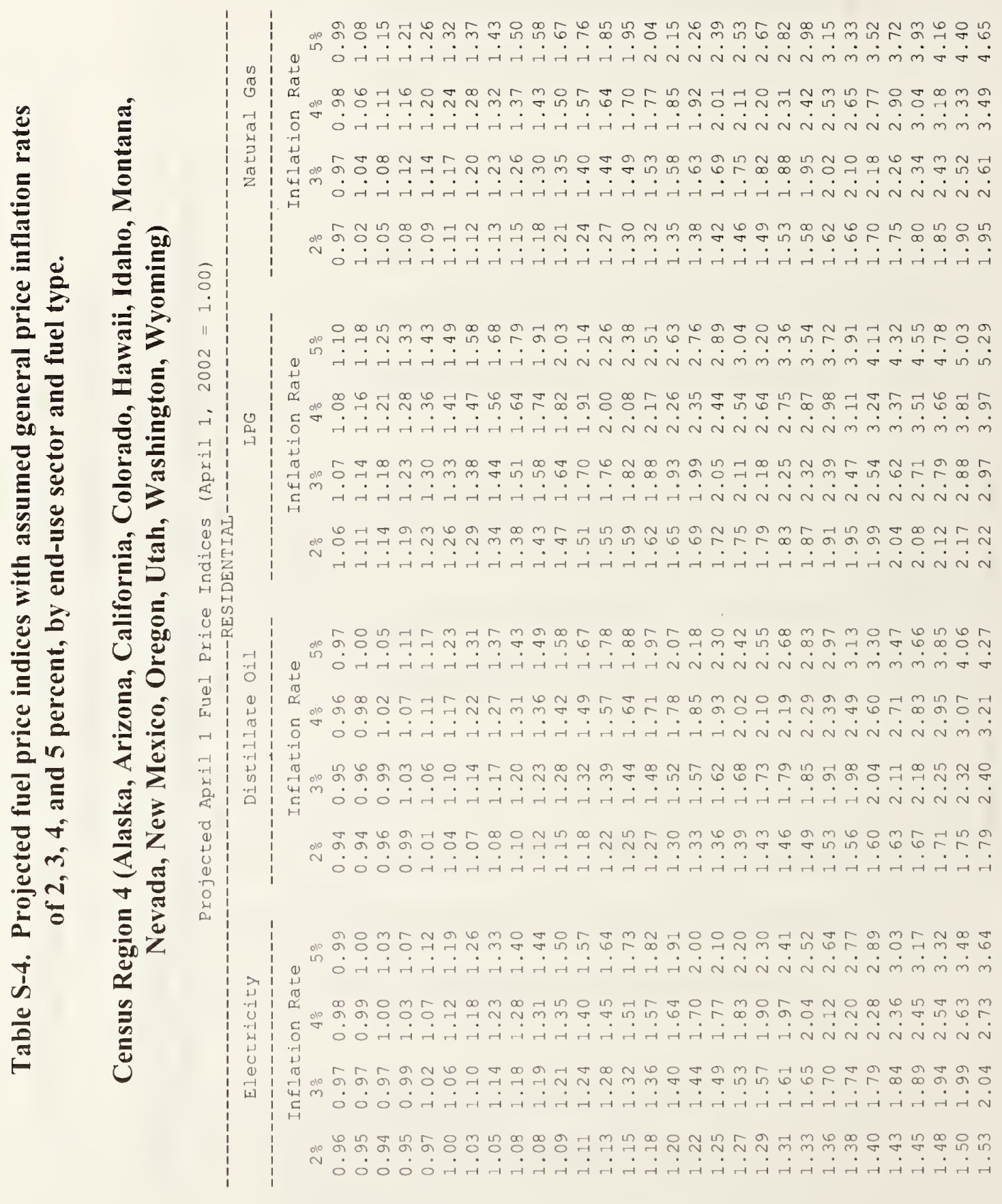

Hm

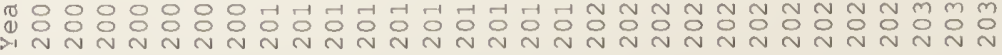




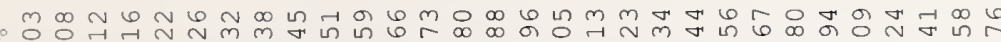

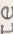
\% N

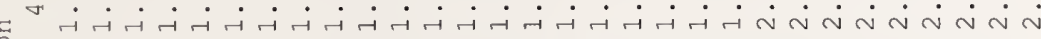

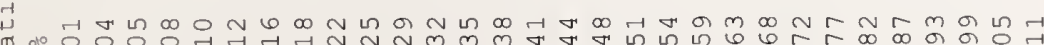
मे

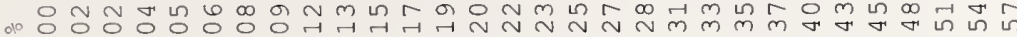

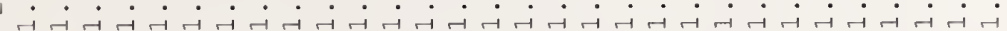

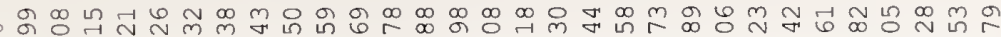

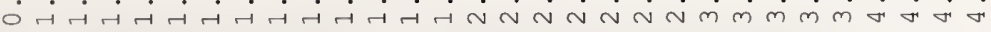
崩 ᄃิ

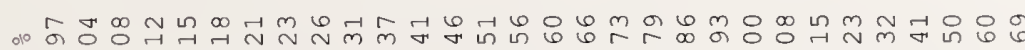

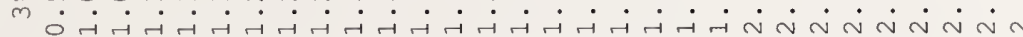
๓

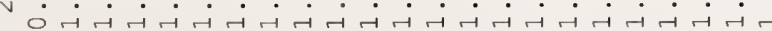

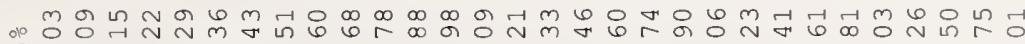

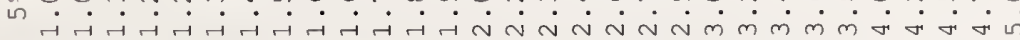
范 س ᄃ

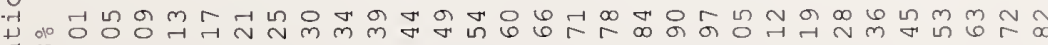
秵

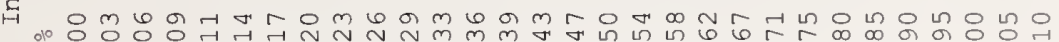
य

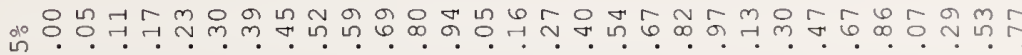

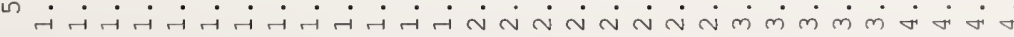
湈 थ ह5

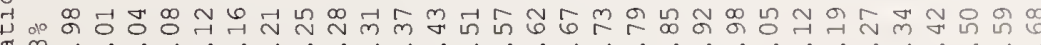

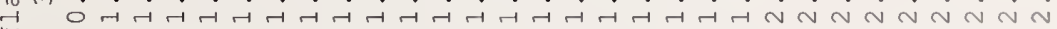

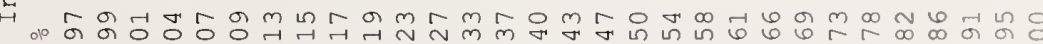
00

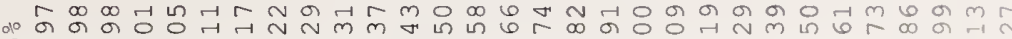

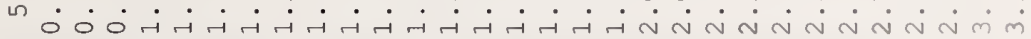

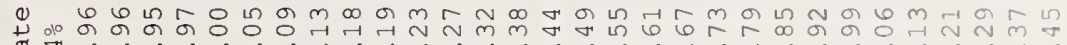

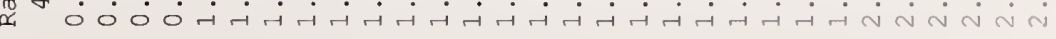

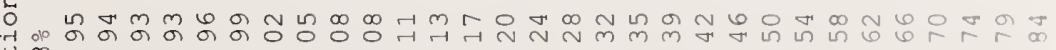
品

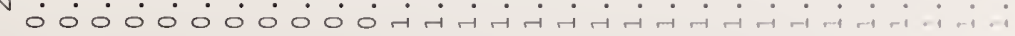

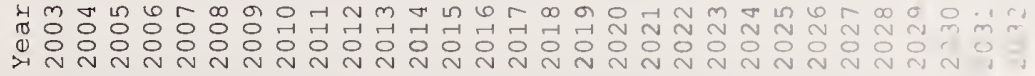




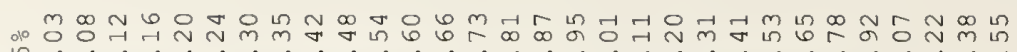
(1) थ व ธ

䒚

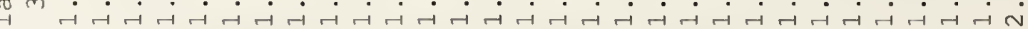

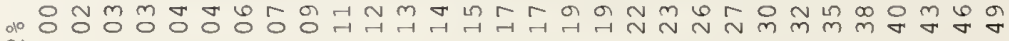

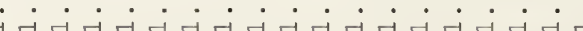

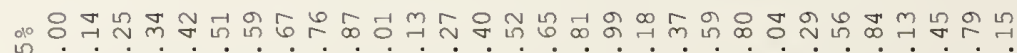
(1)

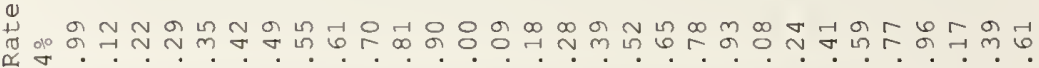
苟

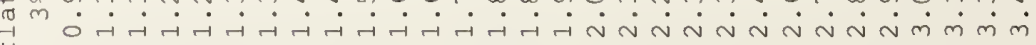

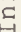

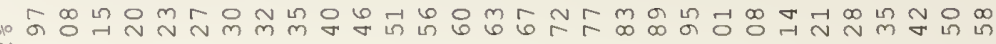

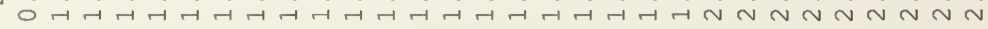

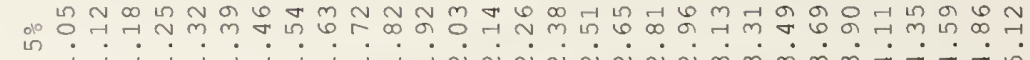
嵌 皮 5

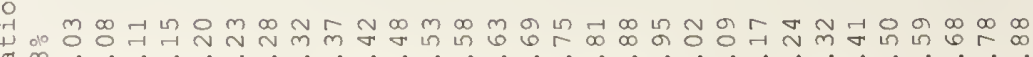

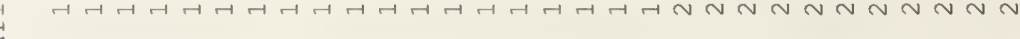

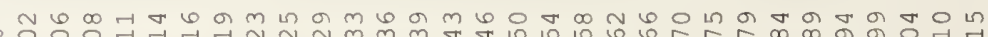
N

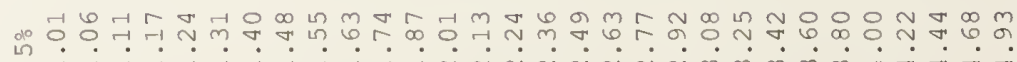

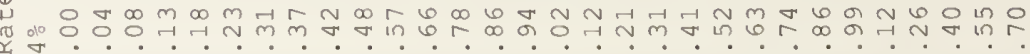
-

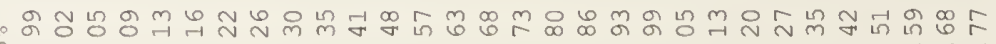

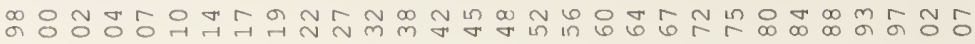
-

ॠ

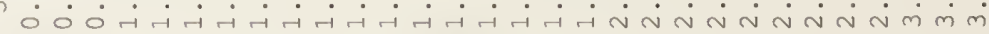

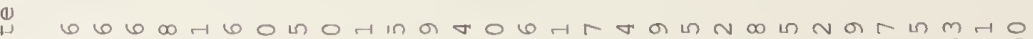
ॠ ๙ ๙ँ Кㅇㅇㅇㅇㅢ

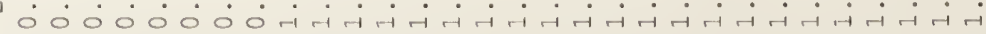

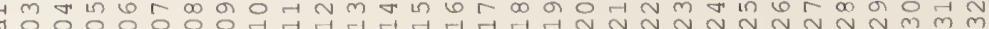

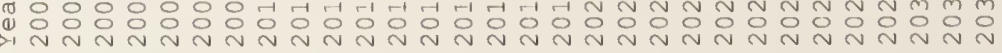




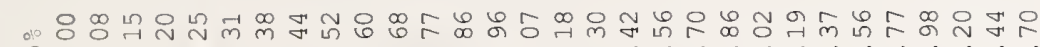

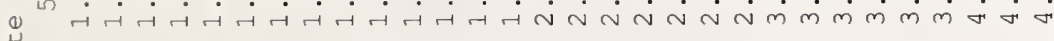
ब1. ठ

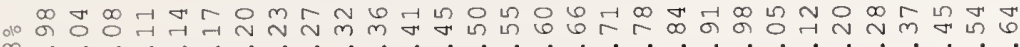

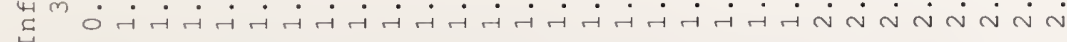

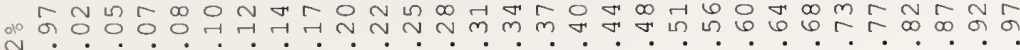

0 -

d0 Q

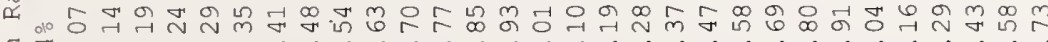
न 开 हा न

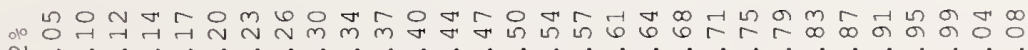
निमें

ॠ (1) 0 ठ

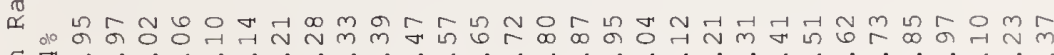

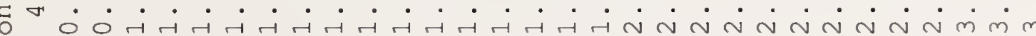
r

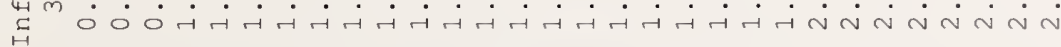
ॠ न न

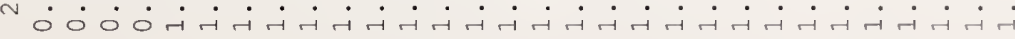

대

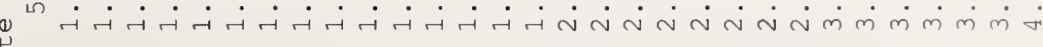
$\stackrel{0}{10}$

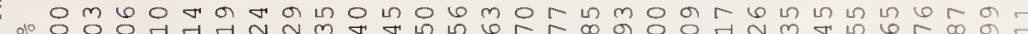
ह म r

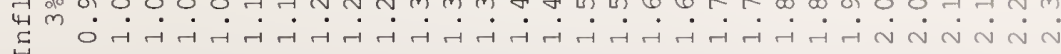
야 \%

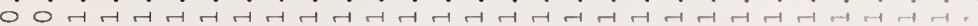

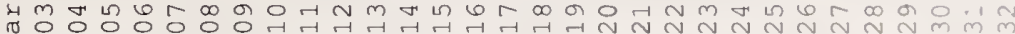

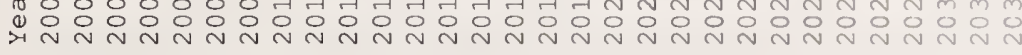


개

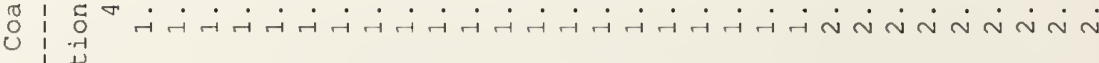

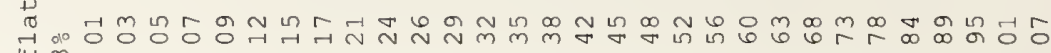
岁

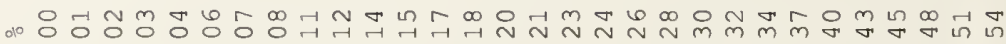
थ में

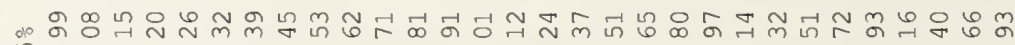

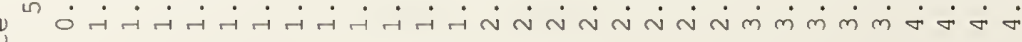
凹

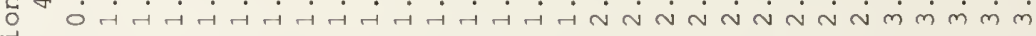
त 岂

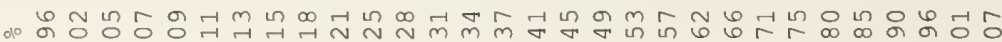

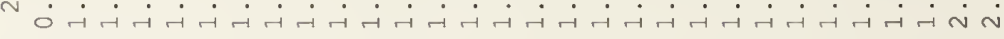

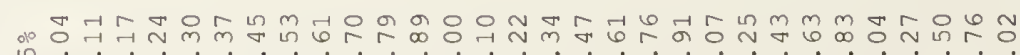

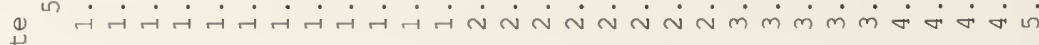

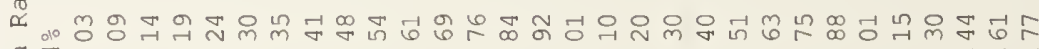
ह

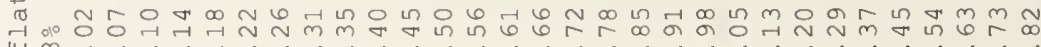
苟

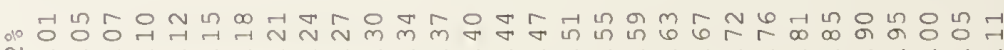
यंत

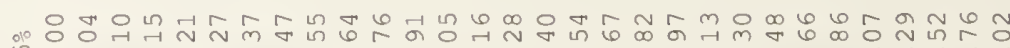
${ }_{10}^{\infty}$ ๙

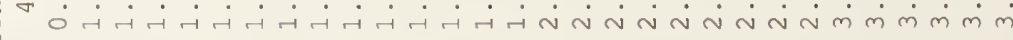

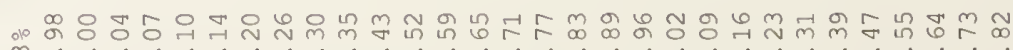

1 0ं

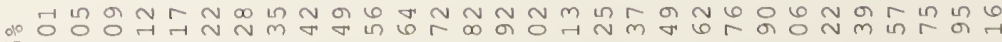

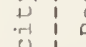

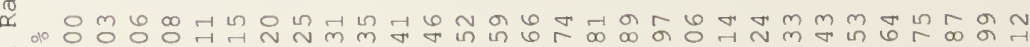

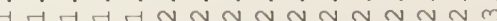
(1) जी

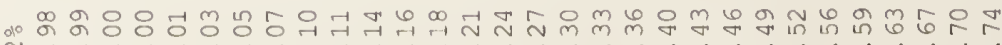
0.

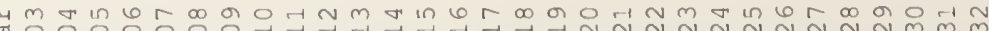

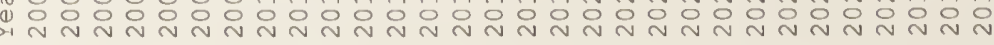




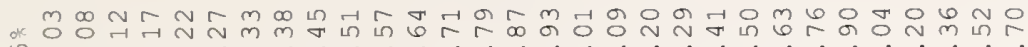

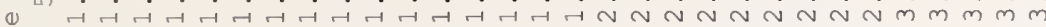
垔

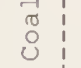
ж 0 의

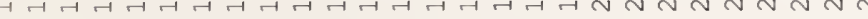
ก

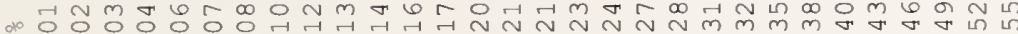

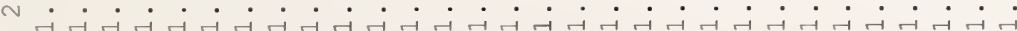

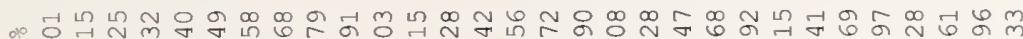

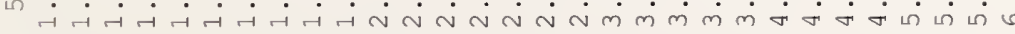
象

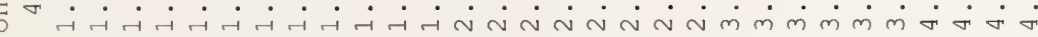

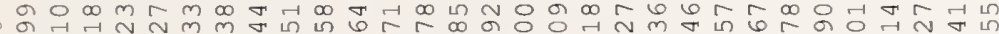

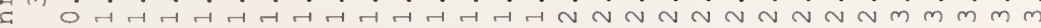

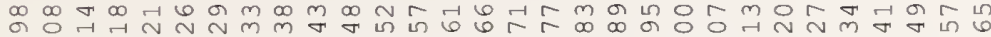

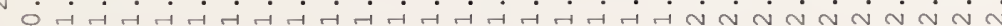

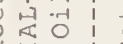

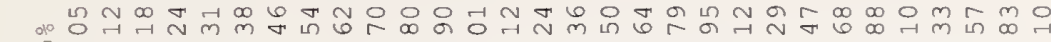

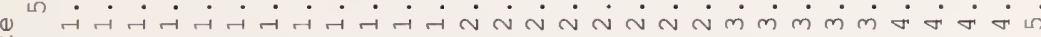

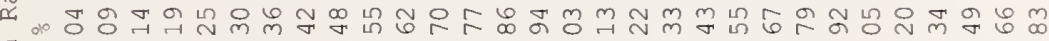
न 苟

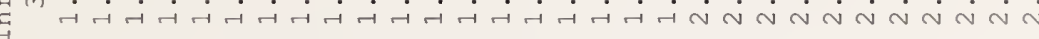

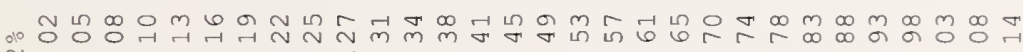

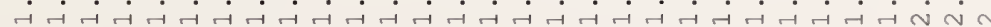

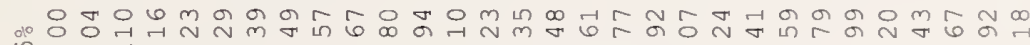
$\stackrel{4}{+}$ ๘

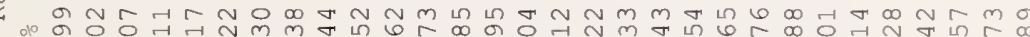

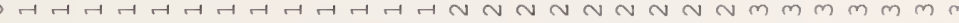
궁 w थ 0ं

Nกㄴ. (1) 悉

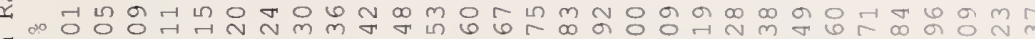

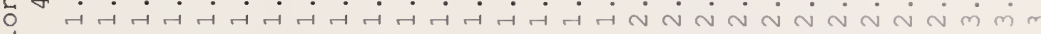
r

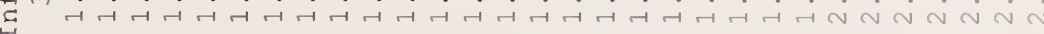

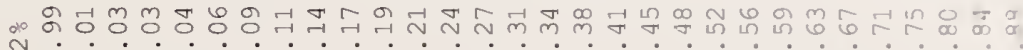

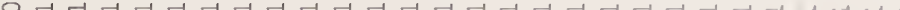

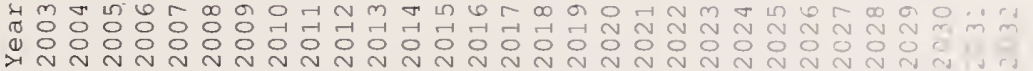



. 
